\title{
Historical Developments of Pyrolysis Reactors: A Review
}

\author{
J.A. Garcia-Nunez ${ }^{1}$, M.R. Pelaez-Samaniego ${ }^{2}$, M.E. Garcia-Perez ${ }^{3}$, I. Fonts ${ }^{4,5}$, J. Abrego ${ }^{5}$, \\ R.J.M. Westerhof ${ }^{6}$, M. Garcia-Perez ${ }^{7} *$ \\ ${ }^{1}$ Colombian Oil Palm Research Centre, Cenipalma, Bogotá, Colombia \\ ${ }^{2}$ Faculty of Chemical Sciences, Universidad de Cuenca, Cuenca, Ecuador \\ ${ }^{3}$ Facultad de Quimico Farmacobiologia, Universidad Michoacana de San Nicolas de Hidalgo, \\ Morelia, Mich., Mexico \\ ${ }^{4}$ Centro Universitario de la Defensa-AGM, Zaragoza, Spain \\ ${ }^{5}$ Grupo de Procesos, Termoquímicos - Universidad de Zaragoza, Spain \\ ${ }^{6}$ Sustainable Process Technology Group, University of Twente, Netherlands \\ ${ }^{7}$ Department of Biological Systems Engineering Department, Washington State University, \\ Pullman, WA, USA
}

\begin{abstract}
This paper provides a review on pyrolysis technologies, focusing on reactor designs and companies commercializing this technology. The renewed interest on pyrolysis is driven by the potential to convert lignocellulosic materials into bio-oil and biochar and the use of these intermediates for the production bio-fuels, biochemicals and engineered biochars for environmental services. This review presents slow, intermediate, fast and microwave pyrolysis as complementary technologies that share some commonalities in their designs. While slow pyrolysis technologies (traditional carbonization kilns) use wood trunks to produce char chunks for cooking, fast pyrolysis systems process small particles to maximize bio-oil yield. The realization of the environmental issues associated with the use of carbonization technologies and the technical difficulties to operate fast pyrolysis reactors using sand as heating media and large volumes of carrier gas, as well as the problems to refine resulting highly oxygenated oils, are forcing the thermochemical conversion community to rethink the design and use of these reactors. Intermediate pyrolysis reactors (also known as converters) offer opportunities for the large scale balanced production of char and biooil. The capacity of these reactors to process forest and agricultural wastes without much preprocessing is a clear advantage. Microwave pyrolysis is an option for modular small autonomous devises for solid waste management.
\end{abstract}


Herein, the evolution of the pyrolysis technology is presented from a historical perspective; thus, old and new innovative designs are discussed together.

Keywords: Pyrolysis reactors, carbonization reactors, thermochemical reactors, bio-oil, char

*Corresponding Author

Manuel Garcia-Perez

Department of Biological Systems Engineering

Washington State University

Pullman, WA, 99164

Phone number: 509-335-7758

e-mail: mgarcia-perez@,wsu.edu 


\section{Introduction}

The practice of carbonizing wood to manufacture char has existed for as long as human history has been recorded ${ }^{1-5}$. Initially, producing char was the sole objective of wood carbonization ${ }^{2,4,5}$ In fact, char is the first synthetic material produced by mankind ${ }^{6,7}$. However, new byproducts (tars, acetic acid, methanol, acetone) were obtained from wood as the civilization progressed and new reactors and bio-oil recovery systems were designed. The ancient Egyptians used pyrolytic liquid products such as fluid wood-tar and pyroligneous acid to embalm their deads ${ }^{5}$. According to the writings of Theophrastus, the Macedonians obtained wood tar from burning biomass in pits ${ }^{4}$. At the end of the eighteenth century, technologies to recover and utilize the condensable pyrolysis products were relatively well developed ${ }^{3,4,8}$. This resulted in brick kilns to recover the condensable gases that were normally lost in the pits. Iron retorts (vessels) followed brick kilns. In the $19^{\text {th }}$ century the "acid-wood industry", also known as the "wood distillation industry" was established ${ }^{9}$ to produce charcoal and liquid by-products (e.g. acetic acid, methanol and acetone). The historical development of carbonization industry is one of the most fascinating in the annals of the Industrial Chemistry ${ }^{1,4}$. The hardwood distillation industry is frequently considered the precursor of the modern petrochemical industry ${ }^{10}$. The rise of the petroleum industry at the beginning of the twentieth century, with cheaper products, caused the decline of the pyrolysis industry. However, the oil crisis during the 1970's forced to reconsider biomass pyrolysis as a technology that could contribute to reduce our dependency on fossil oil. The "fast" pyrolysis reactors were introduced at that time, aiming at maximizing liquid products ${ }^{11-19}$. Recent advances in bio-oil hydrotreatment ${ }^{20,21}$, bio-oil fractionation ${ }^{22-25}$ and new bio-oil derived products (e.g., transportation fuels, phenol formaldehyde resins, carbon fibers) are catalyzing the development of bio-oil refineries. Figure 1 shows important developmental milestones of pyrolysis technology. 
Figure 1. Some important milestones in the development and use of pyrolysis (Adapted from: $:^{2,4,5}$ )

The social and economic impact of wood carbonization in today's world is significant ${ }^{26}$. The wood used as fuelwood and charcoal is about half of the wood extracted from forest, generating income for 40 million people worldwide ${ }^{26}$. The world's top producers of charcoal are (in descendent order): Brazil, Nigeria, Ethiopia, India, the Democratic Republic of Congo, Ghana, Tanzania, China, Madagascar and Thailand ${ }^{26}$. Today this industry contributes with an estimated $\$ 650$ million to Tanzania's economy (300 000 people involved in production and trade) ${ }^{26}$. The Food and Agriculture Organization (FAO) of the United Nations, estimated that 2.4 billion people in developing nations use charcoal as domestic fuel ${ }^{26-31}$. Approximately, 3 billion people still lack access to clean fuels and technologies for cooking ${ }^{26}$. According to the $\mathrm{FAO}^{32}$ more than $52 \mathrm{Mt}$ of charcoal were produced worldwide in 2015 (Africa $62 \%$, Americas: $19.6 \%$ and Asia: $17 \%)^{26}$, showing an increase of close to $20 \%$ since 2005 . Since current char yields a mere 20 wt. \% of the original biomass, it can be estimated that more than $260 \mathrm{Mt}$ of wood are currently processed worldwide to produce charcoal. Between 1 and $2.4 \mathrm{GT} \mathrm{CO}_{2 \text { eq }}$ of greenhouse gases are emitted annually in the production and use of fuelwood and charcoal which represents $2-7 \%$ of global anthropogenic emissions ${ }^{26,33}$. Charcoal produced using sustainable managed resources and improved pyrolysis technologies has the potential to reduce emissions by $80 \%{ }^{26}$. Therefore, there are huge opportunities to improve the environmental performance of current carbonization 
units $^{34-36}$.The potential use of char as a means to fight global warming is also attracting renewed interest on pyrolysis ${ }^{37}$. Char has the capacity to increase soil fertility and sequester carbon ${ }^{38-41}$. Sustainable char technology could offset up to $130 \mathrm{Gt} \mathrm{CO}_{2 \mathrm{eq}}$ emissions during the first century of $\operatorname{adoption}^{39}$. Greening the pyrolysis value supply chain (with sustainable sourcing, production, transport, and distribution) is critical to supporting livehoods and providing energy security in developing nations ${ }^{26}$. The International Energy Agency forecasted that by 2030 charcoal will become a $\$ 12$ billion industry ${ }^{27}$.

According to Scopus, the number of research papers with the keyword "carbonization reactors (CR)" and "fast pyrolysis reactors (FP)" have been steadily growing: 1980-1990 (CR:59 and FP:63 papers), 1990-2000 (CR:86 and FP:88 papers), 2000-2010 (CR:306 and FP:371 papers), 2010-2017 (CR:340 and FP:840 papers). Despite the growing interest to produce bio-oil and char, the disperse information on pyrolysis technologies and manufacturers hinders the development of this industry. There is a vast diversity of factors affecting the pyrolysis process (different feedstocks, scale, capacity, use of mobile or stationary units) which makes it very difficult to find an exclusive design that is sustainable across all the potential feedstocks and applications.

Although there are excellent reviews on fast pyrolysis technologies ${ }^{13-19,42}$, on conventional carbonization reactors $5,6,41,43$, and microwave pyrolysis ${ }^{44,45}$ there are only few reviews on the converters and retorts ${ }^{1,4,9,46}$. Lynch and Joseph ${ }^{47}$, published a guideline for the development and testing of pyrolysis plants for char production. Interestingly, some companies are reproducing old concepts to design new pyrolysis reactors. Thus, the main goal for this paper is to provide a comprehensive overview of pyrolysis reactors. Herein, we describe designs, operating conditions, scale, and yields to help those involved in the development of pyrolysis projects identifying robust flexible designs for their business models. This work is an attempt to present all pyrolysis reactors in a single document within a historical perspective intending that the knowledge and experience generated through centuries could serve as inspiration for the development of new designs. 


\section{Fundamentals of biomass pyrolysis}

The main factors on the operation of pyrolysis reactors affecting the yield and composition of products are: (1) Biomass pyrolysis temperature ${ }^{48}$, (2) Particle size ${ }^{49-51}$, (3) Alkali content ${ }^{52-54}$, (4) Residence time in vapor phase ${ }^{55-57}$, (5) Pressure ${ }^{58-60}$, (6) Pretreatment temperature ${ }^{61,62}$ and (7) Heating rate $55,56,63$. Other factors such as feedstock composition, use of additives, and condensation conditions are outside the scope of this review.

Thermochemical depolymerization reactions are important between 250 and $600{ }^{\circ} \mathrm{C}^{63}$. When biomass is heated, thermal cracking of bonds in biomass constituents (cellulose, hemicellulose and lignin) happens. These primary thermal depolymerization reactions happen in the solid. When biomass macromolecules are heated, some fractions can crosslink and form a solid product $^{63,64}$ and others can depolymerize into light oxygenates that can be easily evaporated ${ }^{65}$ or into oligomeric products that can form a liquid intermediate ${ }^{66-68}$. This liquid intermediate is acidic which enhances dehydration and polycondensation reactions ${ }^{69}$. Most of the pyrolytic water is formed in the liquid intermediate ${ }^{69}$. The oligomeric molecules in the liquid intermediate may be removed from the hot reaction environment in the form of aerosols by thermal ejection ${ }^{66,67}$.

Biomass particle size has a direct impact on heating rate and the release of aerosols, and ultimately on the product distribution of pyrolysis. Indeed, the evacuation of the aerosols formed during the pyrolysis reaction can proceed in two distinct ways depending on the particle size. When very small particles (mostly formed by cell walls) are used, aerosols formed in the pyrolysis reaction can be easily ejected and pyrolysis vapors can be removed without travelling inside the cell cavities ${ }^{50,51}$. Mass transfer limitations increase with particle size. The second regime involves aerosol formation inside cell walls. An important part of these aerosols is retained from escaping through the cell walls and will eventually contribute to the formation of extra char through secondary reactions. Volatile pyrolysis products are also formed inside the particles and will react on their way out of the biomass particle and of the reactor ${ }^{49,50}$. Secondary reactions are typically called intra- and extra- particle homogeneous and heterogeneous reactions ${ }^{49,57,70,71}$. 
The temperature and hydrodynamics of the gaseous reaction environment, the presence of a secondary heating medium (e.g. sand, steel balls, reactor walls, heating tubes) and the size of the biomass particle determine the total conversion time by controlling internal particle heat transfer and reaction kinetics ${ }^{72}$. External heat transfer is determined by the reactor type and its heating method. These factors together define the traditional distinction between slow and fast pyrolysis reactors. The heat transfer in carbonization units operating with logs is controlled by the heat transfer rate inside the wood pile (bed) and inside the logs (typically low heating rates are achieved: less than $100{ }^{\circ} \mathrm{C} / \mathrm{min}$ ). Fast pyrolysis reactors typically operate with very small particles to achieve high heating rates $\left(>1000^{\circ} \mathrm{C} / \mathrm{s}\right)$ inside the particles and high bio-oil yields.

Although there are few studies on the effect of these parameters for all the reactors covered in this review, a discussion for the specific case of fluidized bed reactors is instructive to gain insights on their potential impact in other reactors. Fluidized beds are designed to maximize biooil yields; thus, in order to obtain an adequate gas-solid heat transfer for this purpose, the biomass particles should be very small. This is due to the poor thermal conductivity of biomass (typically around $0.1 \mathrm{~W} / \mathrm{mK}$ along the grain and around $0.05 \mathrm{~W} / \mathrm{mK}$ across the grain). A thin reaction layer may achieve a temperature increase of $10,000{ }^{\circ} \mathrm{C} / \mathrm{s}$, but the low thermal conductivity of wood will prevent this heating rate to occur throughout the entire particle. As the size of the particle increases, secondary reactions within the particle become increasingly significant, leading to the reduction of liquid yields ${ }^{11}$.

Figure 2 shows the effect of some operational parameters on the yield of pyrolysis products in fluidized beds. These studies clearly show that to achieve high bio-oil yields: (i) the pyrolysis temperature should be between 450 and $550^{\circ} \mathrm{C}$, (ii) very small particle sizes should be used, (iii) the residence time of pyrolysis vapors inside the reactor should be minimized, and (iv) alkaline content in biomass should be low $48-50,54,55,73,74$. Data from this figure also suggest that: a) the type of reactor is only one of the several factors controlling product yields, and b) a careful control of the operating conditions (temperature, particle size, ash content) of systems that are not traditionally considered fast pyrolysis reactors could dramatically improve the yield of desirable products. This is especially relevant since most of the literature on fast pyrolysis from 
the 1980s and 90s focused on identifying the very stringent operational conditions that maximize bio-oil yields, while assuming that char should be combusted to provide the energy needed for the process. Instead, currently there is a growing research interest towards the design and use of simpler systems for combined production of bio-oil and char, both presently regarded as valuable products ${ }^{20,75}$. The design of reactors resulting in oils with lower oxygen content and higher yields of gases by taking advantage of the secondary homogeneous reactions in gas phase warrant further investigation. 

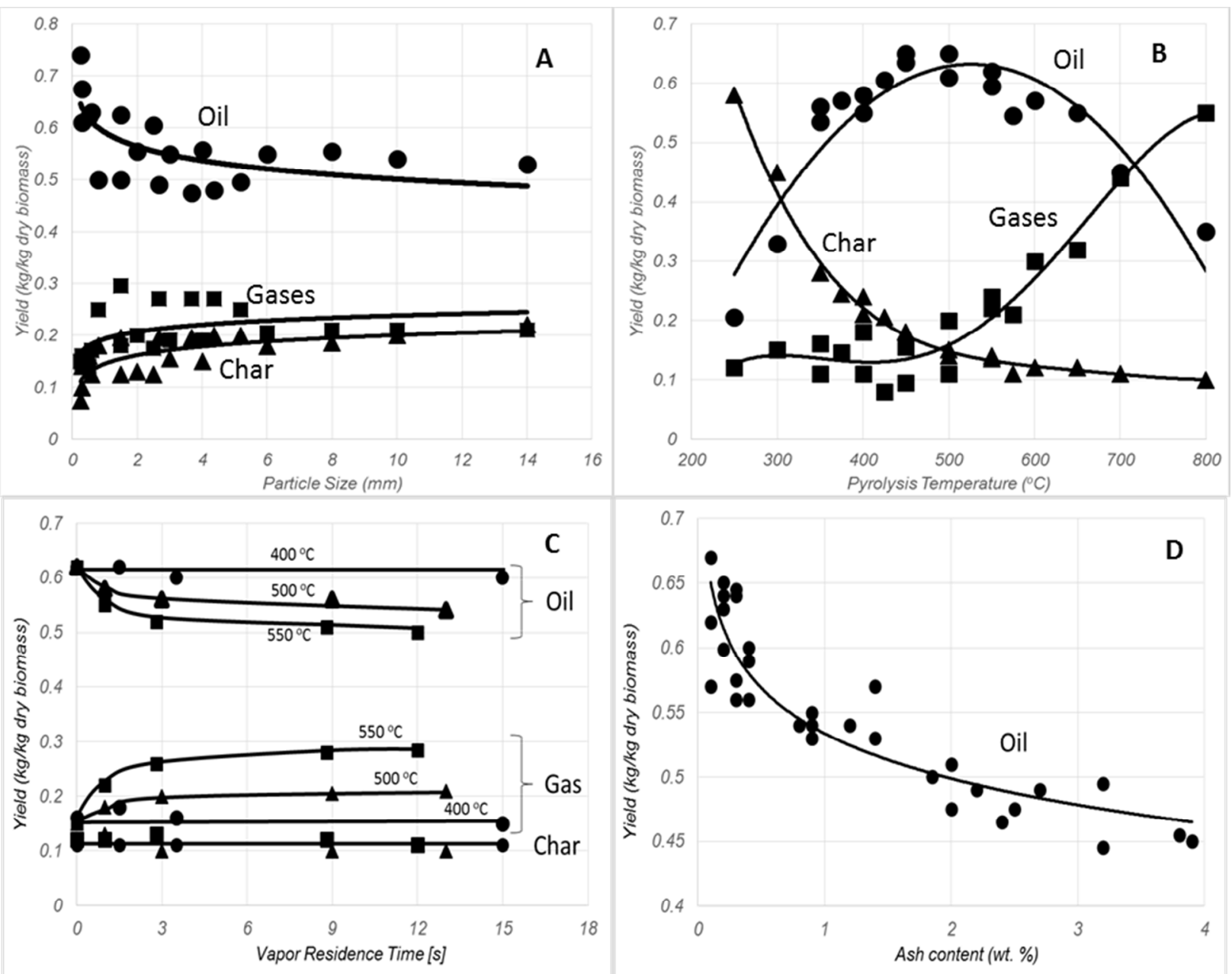

Figure 2. Effect of operational parameters on the yield of products during fast pyrolysis: A: Effect of particle size (Adapted from: ${ }^{49,50}$ ) (Feedstock: Mallee wood ${ }^{49}$, Beech wood ${ }^{50}$ ), B: Effect of Pyrolysis temperature (Adapted from ${ }^{48,74}$ ) (Feedstock: Pine, Beech, Bamboo, Demolition wood $^{48}$, Malee Wood $^{74}$ ), C: Effect of vapor residence time (Adapted from ${ }^{55}$ ) (Feedstock: Pine wood $^{55}$ ), D: Effect of ash content (Adapted from ${ }^{54}$ ).

The interest in reactors capable of producing both char and bio-oil, has resulted in a growing number of designs for the balanced production of both products ${ }^{76,77}$. Figure 3 shows the effect of the temperature on the yield of products obtained when pellets and small particles are processed in a rotary drum and in an auger pyrolysis reactor respectively ${ }^{76,77}$. Although, bio-oil yields in the auger and rotary drum reactors were lower than for fluidized beds (see Figure 2), these 
reactors are easier to operate (use less carrier gas and do not use sand) and do not consume the charcoal for their energy needs. The higher gas yields could help to satisfy an important fraction of the energy needs of these systems. Moreover, pyrolysis gas produced in Auger and rotary drums is less diluted in the carrier gas than in bubbling or circulating fluidized beds, making it more plausible their combustion in conventional boilers and gas engines.
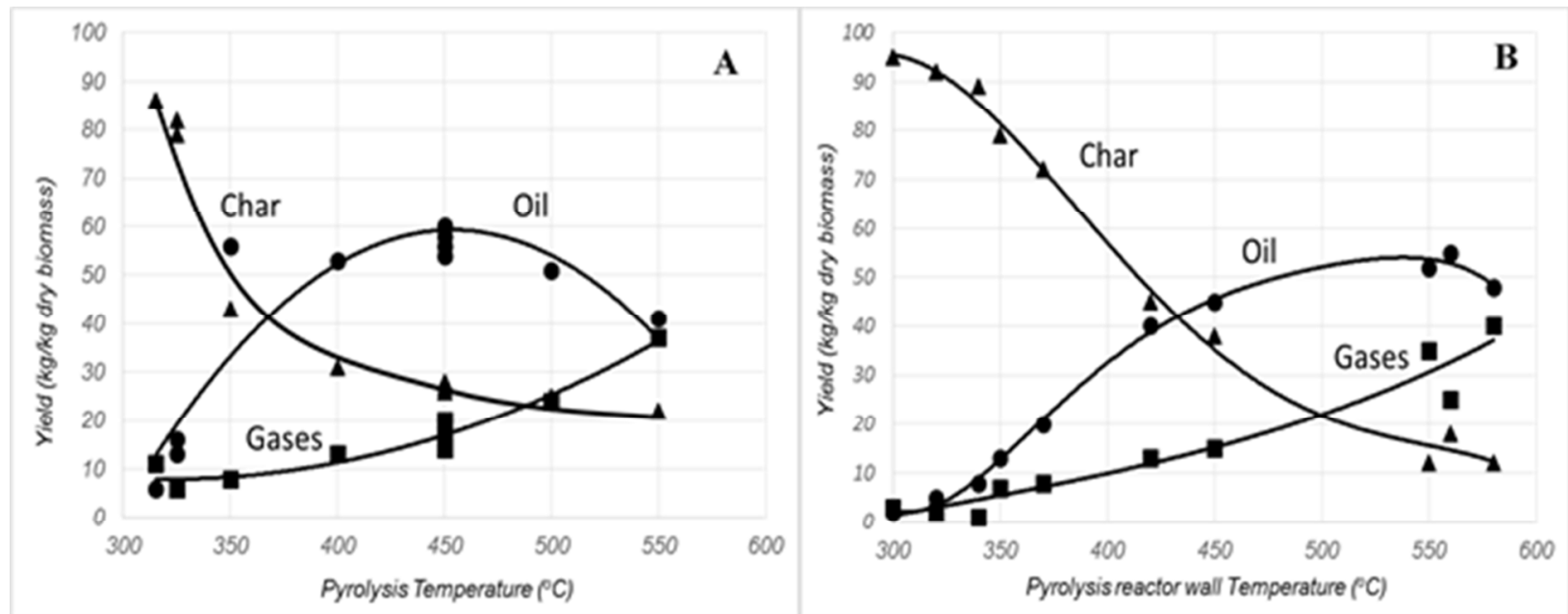

Figure 3. Yield of products in (A) rotary drum (Feedstock: Arbor Pellet ${ }^{76}$ ) and (B) an auger pyrolysis reactor (Feedstock: Douglas Fir Wood ${ }^{77}$ )

\section{Types of pyrolysis reactors}

There are hundreds of pyrolysis reactors designs ${ }^{78}$. Reviewing all of them is out of the scope of this review. Therefore, in this paper we will focus on the reactors most commonly employed. Bridgwater ${ }^{16}$ classified the pyrolysis reactors based on the vapors residence time (VRT) inside the reactor and the time the biomass particle takes to reach final temperature (or heating rate) into: fast (final temperature: $500{ }^{\circ} \mathrm{C}$, particle diameter below $2 \mathrm{~mm}$, VRT: $1 \mathrm{~s}$ ), Intermediate (final temperature: $500{ }^{\circ} \mathrm{C}$, small particles, VRT: $1 \mathrm{~s}$ ), Slow (final temperature: $500{ }^{\circ} \mathrm{C}$, $\operatorname{logs}$ or chips, VRT: days). The term "fast pyrolysis reactors" refers to reactors designed to maximize the yields of bio-oil and typically use powdery biomass as feedstock. Emrich ${ }^{5}$ sub-classified the slow pyrolysis (carbonization) reactors as: kilns, retorts, and converters. The term "kiln" is used to 10 
describe traditional char making equipment, solely employed to produce char from wood logs. Industrial reactors capable of recovering char and products from volatile fractions (liquid condensates and syngas) are herein referred to as "retorts or converters." The term "retort" refers to a reactor able to pyrolyze pile-wood, or wood logs over $30 \mathrm{~cm}$ long and over $18 \mathrm{~cm}$ in diameter". "Converters" produce char by carbonizing small particles of biomass such as chipped or pelletized wood. The converters using small particles, operate at conditions comparable to the intermediate pyrolysis reactors described by Bridgwater ${ }^{16}$. In this review we use the heating mechanism to group the pyrolysis reactors intro: Slow pyrolysis (Kiln, retort), intermediate pyrolysis (converters), fast pyrolysis and microwave pyrolysis reactors $5,16,44,45$. Classification of reactors can also be based on: (1) the final products targeted (oil, char, heat, electricity, gases), (2) the reactor's mode of operation (batch or continuous), (3) the manner in which it is heated (direct or indirect heating, auto-thermal, microwave), (4) the heat source used (electric, gas heater, biomass combustion), (5) the method used to load the reactor (by hand, mechanical), (6) the pressure at which the unit operates (vacuum, atmospheric, pressurized), (7) the material used for the construction of the reactor (soil, brick, concrete, steel), (8) reactor portability (stationary, mobile) and (9) the reactor's position. More information on the classification of pyrolysis reactors can be found elsewhere ${ }^{79}$.

Although the type of pyrolysis reactor and its operating conditions greatly determine the quality of the final targeted products, there is limited information on the open literature linking reactor type, operating conditions and product quality. For charcoal, proximate analysis gives a good indication of its quality. According to Antal and Gronli ${ }^{6}$, fixed carbon content of charcoal for domestic cooking should have volatile matter contents of less than $30 \%$, whereas those of metallurgical charcoal should be $<15 \%$. Ash contents should be between 0.5 and $5 \%$. These values correspond to calorific values between 28 and $33 \mathrm{MJ} / \mathrm{kg}$. For the use of charcoal as biochar (soil amendment), the International Biochar Initiative provides a standardized definition of its characteristics ${ }^{80}$. A common issue in carbonization reactors, especially in batch systems, is the inhomogeneous quality of charcoal due to temperature gradients inside the reactor, uneven gas circulation, partial combustion and heterogeneous wood particle sizes. Thus, in terms of product quality, a good temperature control is a key factor for well-designed retorts or 
converters $^{5}$. The type of reactor is also one of the factors that define bio-oil quality, together with biomass feedstock composition, particle size and condensation system ${ }^{81}$. The desired bio-oil characteristics will differ depending on the targeted final use, i.e, use as a fuel, further upgrading, or use as a product source. From the point of view of bio-oil as a fuel, the multiphase nature of bio-oil is a critical issue ${ }^{81}$. The bio-oil obtained by the fast pyrolysis of relatively dry materials is a homogeneous single-phase oil. The liquid obtained from intermediate, slow and microwave pyrolysis processes is typically formed by a decanted oil and an aqueous phase ${ }^{16}$. The formation of separated phases depends on the relative quantities of the polar compounds (water, sugars, pyrolytic humins), the non-polar compounds (pyrolytic lignin) and the solvents (organic compounds of low molecular weight, such as: methanol, hydroxyacetaldehyde and acetol) $)^{54,81}$. Most of the research on bio-oil properties has focused on fast pyrolysis. Thus, more studies are needed to understand how the type of intermediate and slow pyrolysis reactor and their operational conditions affect bio-oil composition ${ }^{81-85}$ and its multiphase behavior ${ }^{54,81,86}$.

\section{Kilns (Carbonization methods)}

This section covers examples of the main groups of "kilns": earth (mound, pit) and brick/concrete/metal (Brazilian, Argentine, Missouri, TPI) (Figure 4). There are excellent reviews and books covering these reactors $5,87,88$. Therefore, this section will focus on the generalities and recent publications related with these reactors. Since, the number of recent publications on these reactors is limited, the information herein reported relates mostly with operating conditions of reactors in real settings.

Earth kilns (mound pit) have been used for centuries; and are still very popular in some developing countries ${ }^{41}$. Soil is used as a barrier for oxygen attack to prevent high levels of oxidation. The liquids (condensates) released during carbonization on the soil and the vapors released to the atmosphere are important sources of pollution. Two types of earth kilns are distinguished: pit kilns and mound kilns (sometimes referred to as earth-mound kiln) (Figure 4). When the soil is well drained, deep and easy to excavate pit kilns are preferred ${ }^{89}$. The main advantage of these kilns is their low capital investment. However, the circulation of air is 
difficult to control and are harmful to the environment with the emission of vapors to the atmosphere and the condensation of oils in soils ${ }^{89}$.

Mound kilns can be classified into three types: vertical mound kiln, horizontal mound kiln, and improved mound kiln designs (the Casamance mound kiln) ${ }^{90}$. Casamance-type kilns, which use oil drums as chimneys, are the result of improvements made during the 1970's and 1980's. The Casamance kiln can typically produce up to 1.7 times more charcoal than a traditional earth kiln (i.e., reaching efficiencies from $20 \mathrm{wt} \%$ in pit kilns to $34 \mathrm{wt} \%$ ) $^{27,29,90,91}$. A number of factors, such as location of kilns, conditions and type of wood, as well as qualification of operators, greatly affect the carbonization efficiency of earth mound kilns. This explains why some publications present different yields for similar types of kilns operating in different places. For example, Mangue ${ }^{27}$ reports efficiencies from 12 to $16 \%$ in Mozambique. Schenkel et al. ${ }^{90}$ show tables comparing efficiencies of similar kilns operated in other latitudes, with efficiencies varying from 12 to $34 \%$. Kammen and $\mathrm{Lew}^{29}$ show the charcoal energy yield as a function of the kiln size for traditional kilns and the Casamance kiln, noticing a better efficiency of the latter. The average energy efficiency is around $18 \%$ for the traditional kiln and $32 \%$ for the Casamance $\mathrm{kiln}^{29}$. Menemencioglu ${ }^{92}$ reported data on wood charcoal production in Turkey. The author collected data from 44 kilns ranging from 25 to $45 \mathrm{~m}^{3}$, which were built by 23 adults. Typically, $1 \mathrm{~kg}$ of charcoal was obtained from every 5 to $6 \mathrm{~kg}$ of biomass, using 1350 tons oak and having 255 tons of charcoal. The average productivity was $11 \mathrm{t}$ of charcoal per adult for the 7 month production season. The wholesale price was $\$ 0.7 \mathrm{~kg}^{-1}$ resulting in an average income of $\$ 7,761$ per season (7 months) ${ }^{92}$.

The main advantage of earth mound kilns is that they are simple, made of earth and can be built in the same area that the biomass is available. This technology is well suited to operate with logs. Its final product (charcoal chunks) can be easily commercialized as domestic fuel in some developing nations. No special equipment is required and the initial investment is low $\left(\$ 27 / t^{87}\right)$. This kiln is easy to operate and very flexible with regards to capacity ${ }^{89}$. Its main disadvantages are: high labor demand, char is dirtied by the covering, sensitiveness to weather conditions, very poor control of carbonization, low efficiency, difficulty to carbonize small size agricultural 
wastes and the release of very large quantities of organic pollutants ${ }^{89}$. A detailed description on the construction and operation of earth kilns can be found elsewhere ${ }^{10,88,89}$. Some of the main characteristics of these kilns are presented in Table 1.
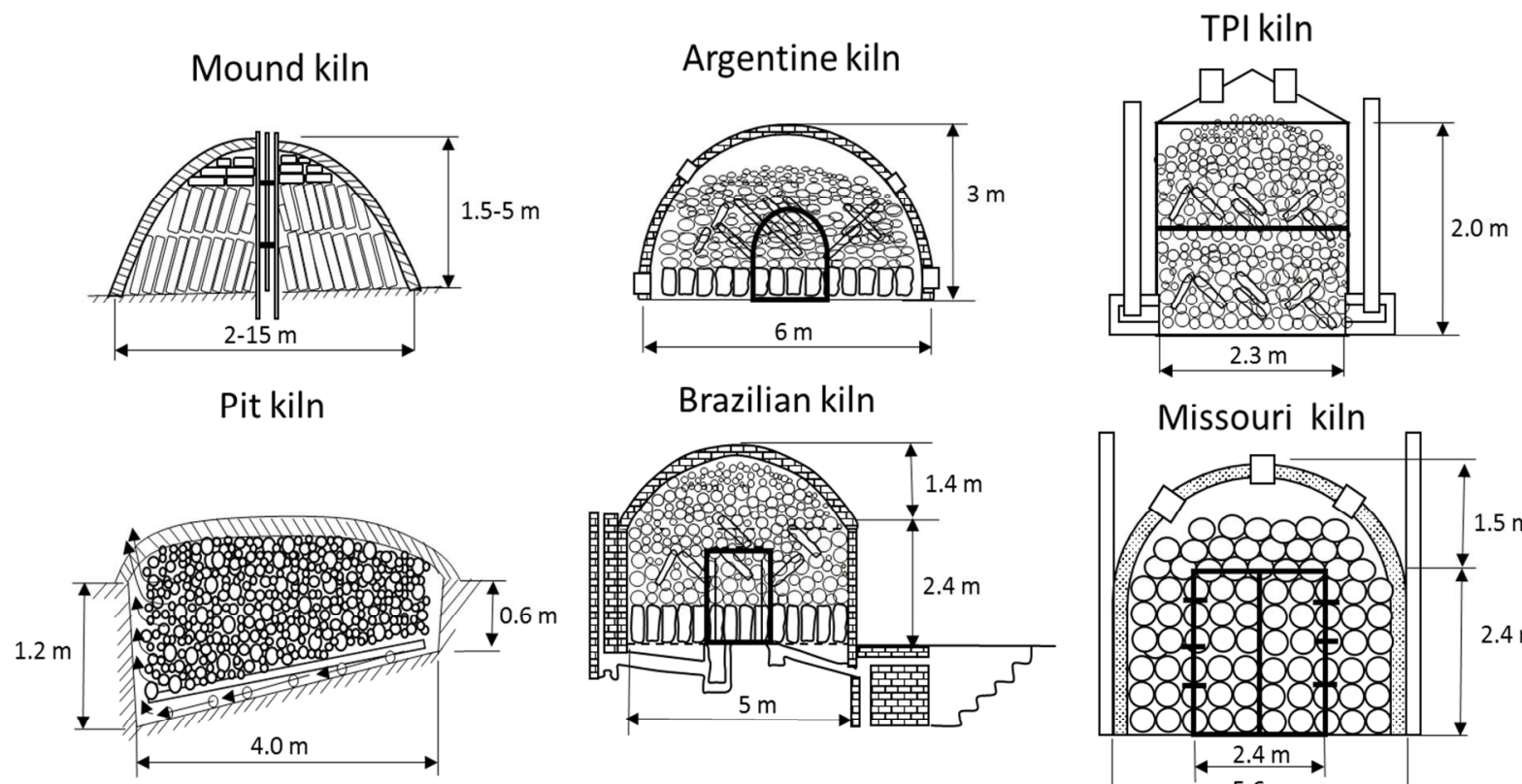

Figure 4. Schematic representation of typical kilns. Dimensions are presented for reference only (Adapted from: ${ }^{5,88,89}$ ).
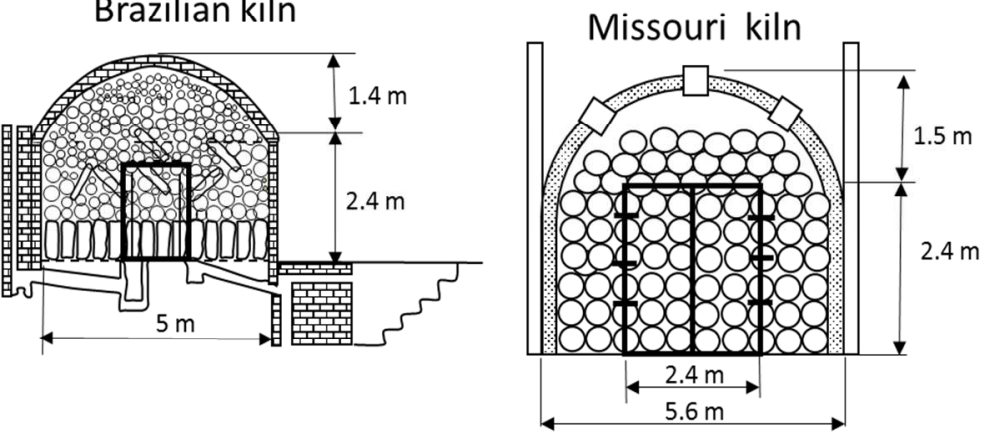
Table 1. Characteristics of kilns for charcoal production

\begin{tabular}{|c|c|c|}
\hline & Earth kiln & Cinder block, brick and metal kilns \\
\hline Types/Representative kilns & Pit kilns and Mound kilns & $\begin{array}{l}\text { Brazilian beehive and Half orange kiln, } \\
\text { Argentine beehive kiln, Adam retort, TPI } \\
\text { kiln, New Hampshire, Connecticut kiln, } \\
\text { Missouri kiln }\end{array}$ \\
\hline Construction materials & Earth & Cinder/brick/concrete/Iron bands ${ }^{44}$ \\
\hline Portability & Built in place & Stationary \\
\hline Carbonization duration & $1-5$ weeks $^{89}$ & $10-30$ days $^{43,89}$ \\
\hline Capacity***** & $\begin{array}{l}\text { Mound: } 50-32,000 \mathrm{~kg}\left(3-330 \mathrm{~m}^{3}\right)^{93} \\
\text { Casamance: } 50-1,000 \mathrm{~kg}^{87}\end{array}$ & $\begin{array}{l}\text { Brazilian: } 20 \mathrm{t}^{87} \\
\text { Argentine: } 30 \mathrm{t}^{87} \\
\text { Missouri: } 80 \mathrm{t}^{87}\end{array}$ \\
\hline Charcoal yields reported & $\begin{array}{l}\text { Pit kiln: } 12-30 \text { wt. } \%{ }^{29} ; 12-16 \text { wt. } \\
\%^{28} \\
\text { Mound: } 2-42 \text { wt. } \%{ }^{29} \\
\text { Casamance: } 30 \text { wt. } \%{ }^{87}\end{array}$ & $\begin{array}{l}\text { Brick: } 12-33 \text { wt. } \%^{29} \\
\text { Portable Steel (TPI): } 19-31 \text { wt. } \%{ }^{29} \\
\text { Missouri: } 33 \%{ }^{29}\end{array}$ \\
\hline Loading and discharge methods & Manual & Manual/Mechanical \\
\hline Dimension of reactor & $\begin{array}{l}\text { Pit kiln: depth } 0.6-1.2 ; \text { length: } 4.0 \\
\text { m, capacity: } 1-30 \mathrm{~m}^{3} \\
\text { Mound kiln: diameter: } 2-15 \mathrm{~m} \text {; } \\
\text { height: } 1-5 \mathrm{~m} \text { (volumes: } 8-156 \mathrm{~m}^{3} \text { ) }\end{array}$ & $\begin{array}{l}\text { Brazilian/Argentine: diameter: } 5-7 \mathrm{~m} \text {, } \\
\text { high: } 2-3 \mathrm{~m} \text { producing } \\
\text { Missouri kiln: wide: } 7 \mathrm{~m} \text {, length: } 11-13 \\
\mathrm{~m} \text {, height: } 3.5-4 \mathrm{~m}, \\
\text { TPI kiln: diameter: } 2.3 \mathrm{~m} \text {, high: } 2 \mathrm{~m}\end{array}$ \\
\hline Reactor capital cost & $\begin{array}{l}\text { Mound: } \$ 27 / \text { charcoal }^{87} \\
\text { Casamance: } \$ 200^{87}\end{array}$ & $\begin{array}{l}\text { Brazilian: } \$ 150-1,500^{87} \\
\text { Missouri: } \$ 15,000^{87}\end{array}$ \\
\hline Charge ignition method & Small kindled wood at midpoint & $\begin{array}{l}\text { Small kindle wood/burning oil/gas fired } \\
\text { torch }\end{array}$ \\
\hline Process control & $\begin{array}{l}\text { Observing color of produced } \\
\text { vapors }\end{array}$ & $\begin{array}{l}\text { Observing color of produced vapors or } \\
\text { temperature measurements }\end{array}$ \\
\hline Raw material used & \multicolumn{2}{|l|}{ Cordwood } \\
\hline Final product targeted & \multicolumn{2}{|l|}{ Char } \\
\hline Heat transfer rate achieved & \multicolumn{2}{|l|}{ Slow Pyrolysis } \\
\hline Mode of operation & \multicolumn{2}{|l|}{ Batch operation } \\
\hline Heating method & \multicolumn{2}{|c|}{ Partial combustion of foliage (auto-thermal process) } \\
\hline Pressure & \multicolumn{2}{|l|}{ Atmospheric } \\
\hline
\end{tabular}

Brick/concrete/metal: The four main kilns reviewed in this section are: Brazilian, Argentine, Missouri and the TPI kilns (Figure 4). In the US, during the $19^{\text {th }}$ century, earth kilns were replaced by the so called "beehive kilns", ${ }^{\prime 94}$. The basic difference between earth kilns and cinder block and brick kilns is the construction material (Table 1). These kilns have a long lifespan and several types have proved their economic viability. Cinder block and brick kilns can be differentiated by their shape: hangar kilns, with rectangular or square shape, and round brick kilns $^{5}$. The main advantages of brick kilns are the use of local materials, higher yields than mound and pit kilns, good quality charcoal, good thermal isolation, easy operation, lifespan of 6 to 10 years and they are not sensitive to climate conditions ${ }^{89}$. These kilns can operate with logs and the final products (charcoal chunks) can be easily commercialized as domestic fuel. The 
main disadvantages of brick kilns are associated with the need of skilled workers for their construction, fixed location, long production cycle (on average 15 days, the cooling process is slow), and higher construction and operating costs than mound and pit kilns. These kilns are also responsible for important air pollution ${ }^{5}$. The most commonly used round brick kilns are: the Argentinean half-orange kiln and the Brazilian beehive kiln (see Figure 4). The most commonly used hangar kilns is the Missouri kiln (See Figure 4). All these kilns are auto-thermal and operate by burning part of the charge within the kiln.

The Brazilian brick kiln is an internally heated, fixed, batch-type kiln widely operated in Brazil, especially in the state of Minas Gerais and in the Amazonian region, with a typical capacity of 45 $\mathrm{m}^{3}{ }^{43}$. Thousands of them are used to produce charcoal for the Brazilian iron and steel industry ${ }^{5}$, 95. A detailed description of the methods to build and operate these kilns can be found elsewhere $^{88,96}$. A typical operational cycle consists of 8 hours for loading/discharging, 80 hours for carbonization and 70 hours for cooling ${ }^{43}$. Some of the most advanced modifications to the Brazilian kilns are the attachment of an external heating chamber and the reduction of the number of smoke stacks ${ }^{5}$. Branches, brushwood, and other residual materials, which are not suitable for charcoal production and would be otherwise wasted, are used to heat the kiln. The raw material used for carbonization is typically cordwood, obtained from dedicated plantations or from forest clear cutting ${ }^{5,96}$. These kilns can be modified to recover pyroligneous water and decanted oil. Only few research papers describe the operation and yield of products from Brazilian kilns ${ }^{97}$.

The Argentine kiln is also generally referred to as the "half-orange-kiln" due to its hemispherical shape. This kiln, like many others, can be built in various sizes. Unlike the Brazilian kiln, Argentine kilns are built completely out of bricks with no iron parts ${ }^{5}$. A detailed description on how to build and operate a half-orange kiln can be found elsewhere ${ }^{88}$.

Missouri-type kilns are sometimes referred to as concrete kilns ${ }^{38}$ or batch-type charcoal kilns ${ }^{98}$. They can be built with volumes up to $350 \mathrm{~m}^{3}$ (typically between 150 and $200 \mathrm{~m}^{3}$ ) 27,31,43,98, thus, requiring mechanized loading and unloading ${ }^{10,31}$. The operational cycle consists of 4 days of 
loading/discharging, 6 days of carbonization and 20 days of cooling ${ }^{43}$.The Missouri charcoal kiln, which was developed at the beginnings of the 1950s by V. Wulff in the Ozark County (Missouri) $^{27}$, is a well proven kiln ${ }^{5,10,38,99}$. Missouri-type kilns are still used in Missouri, United States $^{41,98,99}$ and are responsible for an important fraction of the charcoal produced in the USA ${ }^{98,}$ 100, 101 . Several improvements have been made to the original design. For instance, using thermocouples within the kiln contributes to the identification of cold ports and controlling airflow $^{38}$. Additionally, the environmental impact of these kilns can be reduced by using afterburners $^{78,98,100,102}$ More information on the design and operation of this kiln can be found elsewhere $^{5,10,31}$.

The TPI kiln is a small size kiln developed by the Tropical Products Institute (TPI) (Figure 4). This kiln is built with two interlocking cylindrical sections and a conical cover with ports to release vapors ${ }^{38,88}$. Eight channels located at the perimeter of the base section support the kilns and serve as air inlets or smoke stacks. Compared to earth kilns, air inlet and gas outlet are easy to control, with less supervision needed. All the carbon produced can be recovered. These reactors can be transported to the place the feedstock is collected. They produce high charcoal yields with relatively short carbonization times (around three days). These kilns can be easily operated in high rainfall regions. However, they have important air pollution issues ${ }^{38,88}$. Other disadvantages include: higher capital costs compared with earth kilns, the need to cut and split biomass to fit inside the kiln, difficult transportation in hilly terrain, and a relatively short lifespan (only 2-3 years) ${ }^{89}$.

The emission of gases and particulates from charcoal production in rural areas using mediumsized traditional and improved kilns has been studied by Sparrevik et al ${ }^{103}$. They reported the following average emission levels: $1,950 \mathrm{~g} \mathrm{CO}_{2} / \mathrm{kg}$ charcoal, $157 \mathrm{~g} \mathrm{CO} / \mathrm{kg}$ charcoal, $6.1 \mathrm{~g}$ nonmethane organic volatile compounds/kg charcoal, $24 \mathrm{~g} \mathrm{CH}_{4} / \mathrm{kg}$ charcoal, $24 \mathrm{~g}$ solid particles $/ \mathrm{kg}$ charcoal and $1.8 \mathrm{~g} \mathrm{NO}_{\mathrm{x}} / \mathrm{kg}$ charcoal $^{103}$. 
Other important kilns reported in the literature not discussed in this section include: New Hampshire kiln ${ }^{104,105}$, Connecticut kiln ${ }^{10,104,106 ; 107}$, Black Rock Forest kiln, 10,106,107, Rima Contained kiln $(R C K)^{93}$, the Adam retort ${ }^{103,108,109}$, and the European Schwartz kiln ${ }^{5}$.

\section{Retorts}

While kilns are typically closed containers releasing gas and vapor to the atmosphere, the retorts condense the vapors and make good use of the energy content of gases ${ }^{89,110}$. The main reactors discussed in this section are: the wagon reactor, Lambiotte French SIFIC (http://www.lambiotte.com/), the Lurgi Process ${ }^{111}$ and the Carbon Twin Retort ${ }^{12}$ (Figure 5). All these systems operate with logs. Their main characteristics are listed in Table 2. The main advantages of these systems are associated with the high charcoal yield and high charcoal quality. Additionally, the by-products from the vapors can be recovered. The main disadvantages are related with the high capital costs, attrition problems, the need of external sources of energy and the fact that most of these systems are not portable and require a concentrated supply of raw materials ${ }^{89}$.

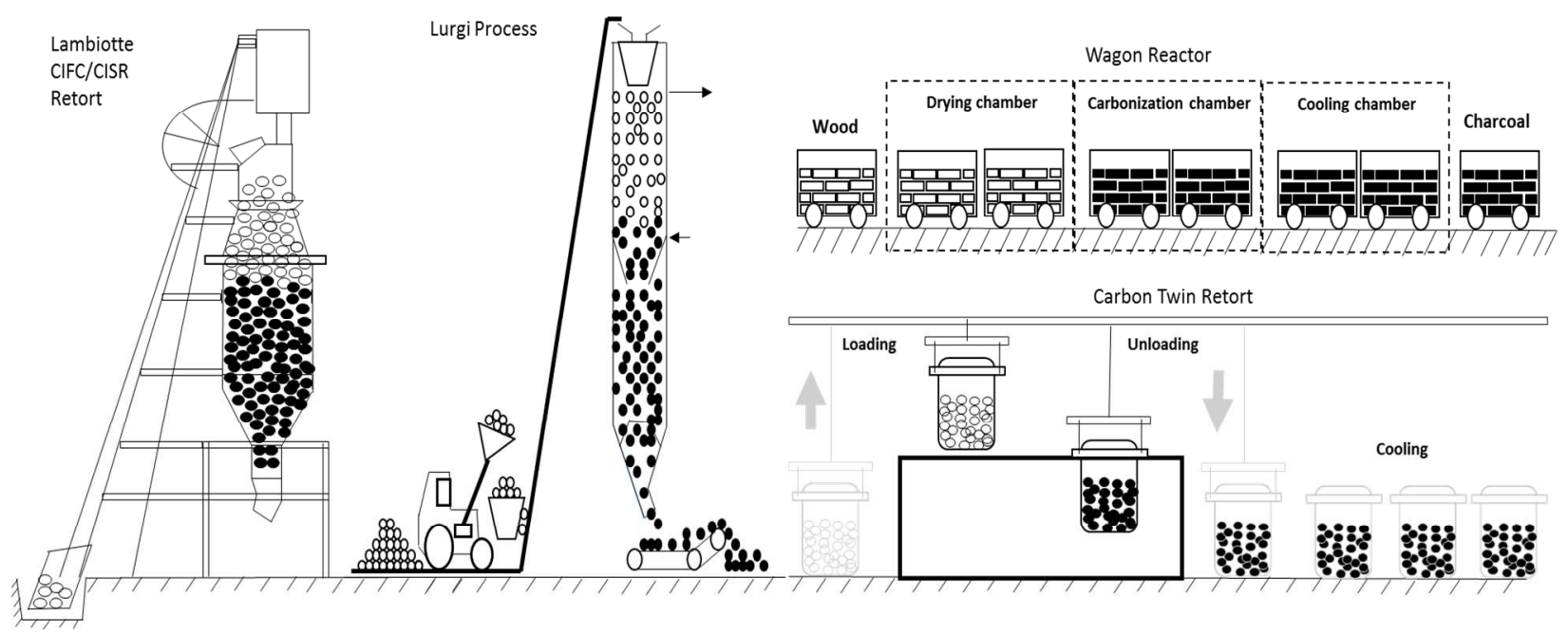

Figure 5. Schematics of Retorts (Adapted from ${ }^{88,110-112}$ ) 
Table 2. Characteristics and operational details of some retorts operating with logs

\begin{tabular}{|c|c|c|c|c|}
\hline & Lurgi & $\begin{array}{l}\text { Lambiotte French } \\
\text { SIFIC }\end{array}$ & The wagon retort & $\begin{array}{l}\text { Carbo Twin } \\
\text { Retort }\end{array}$ \\
\hline Final product targeted & \multicolumn{4}{|c|}{ Char } \\
\hline $\begin{array}{l}\text { Heat transfer rate } \\
\text { achieved }\end{array}$ & \multicolumn{4}{|c|}{ Slow pyrolysis } \\
\hline Capacity & $\begin{array}{l}6.2 \mathrm{t} \mathrm{wood} / \mathrm{h}^{111} \\
\text { (per unit) } \\
13,000 \mathrm{t} \\
\text { charcoal } / \text { year } \\
\text { (per unit) }\end{array}$ & $\begin{array}{l}2,000-6,000 \mathrm{t} / \text { year } \\
\text { (per unit }^{87}\end{array}$ & 6,000 t/year ${ }^{87}$ & $\begin{array}{l}900 \mathrm{t} / \mathrm{year} \text { per } \\
\text { furnace } 112\end{array}$ \\
\hline $\begin{array}{l}\text { Production per unit } \\
\text { reaction volume }\end{array}$ & $10 \mathrm{t} /$ year $/ \mathrm{m}^{3}$ & $16 \mathrm{t} /$ year $/ \mathrm{m}^{3}$ & & $70 \mathrm{t} /$ year $/ \mathrm{m}^{3}$ \\
\hline Carbonization time & $\mathrm{n} / \mathrm{a}$ & $\mathrm{n} / \mathrm{a}$ & $25-35 \mathrm{~h}$ & $\begin{array}{c}8 \mathrm{~h} \\
\text { (carbonization), } \\
24-48 \mathrm{~h} \text { (cooling) }\end{array}$ \\
\hline Heating method & \multicolumn{2}{|c|}{ Contact with heat gases } & \multicolumn{2}{|c|}{$\begin{array}{l}\text { External heat \& volatile combustion, an } \\
\text { oil burner (or LPG) is used to provide } \\
\text { heat for the initial start-up }\end{array}$} \\
\hline Dimensions & $\begin{array}{l}\text { Height: } 27 \mathrm{~m} \\
\text { Diameter: } 3 \mathrm{~m} \\
\text { Woodfeed size: } \\
150 \mathrm{~mm} \times 150 \\
\mathrm{~mm} \times 250 \mathrm{~mm}\end{array}$ & $\begin{array}{c}\text { Height: } 16.3-18 \\
\mathrm{~m}^{110} \\
\mathrm{D}=3-4.3 \mathrm{~m}^{43} \\
\text { Volume: } 600 \mathrm{~m}^{3}\end{array}$ & $\begin{array}{c}\text { Trolleys: } 12 \mathrm{~m}^{3} \\
\text { Length: } 8-16 \mathrm{~m} \\
\text { Diameter: } 2.5 \mathrm{~m} \\
\text { Tunnel capacity: } 35- \\
60 \mathrm{~m}^{3} \\
\text { Length: } 45 \mathrm{~m} \text { long }\end{array}$ & $\begin{array}{c}\text { Volume per } \\
\text { Vessel: } 5 \mathrm{~m}^{3} \\
\text { Six vessels are } \\
\text { needed to keep the } \\
\text { system running }\end{array}$ \\
\hline Construction materials & \multicolumn{4}{|c|}{ Steel } \\
\hline Portability & \multicolumn{4}{|c|}{ Stationary } \\
\hline Reactor Position & Vertical & Vertical & Horizontal & Vertical \\
\hline Raw material used & Cordwood & Cordwood & Cordwood & \\
\hline $\begin{array}{l}\text { Loading and discharge } \\
\text { methods }\end{array}$ & Mechanical & Mechanical & Use of wagons & \\
\hline Process control & \multicolumn{3}{|c|}{ Direct measurement of temperature } & \\
\hline Mode of operation & & Continuous & & Semi-continuous \\
\hline Pressure & \multicolumn{4}{|c|}{ Atmospheric } \\
\hline Efficiency & $30-40 \%$ & $35 \%$ & & $30 \%$ \\
\hline Pretreatment needed & \multicolumn{4}{|c|}{ Pre-dried } \\
\hline Cost & $\begin{array}{l}\text { Capital cost: } \$ \\
10 \text { million } \\
(1989) \\
\text { Operating cost: } \\
\text { EUR 320/t } \\
\text { charcoal }\end{array}$ & $\begin{array}{l}\text { Capital cost: } 0.5-2 \\
\text { million dollars } \\
\\
\text { Capital cost: EUR } \\
360 / \mathrm{t} \text { charcoal }\end{array}$ & & $\begin{array}{c}\text { Capital cost: } \\
480,000 \text { EUR } \\
\text { Char sales price: } \\
250 \text { EUR/t }{ }^{112} \\
\text { Operating cost: } \\
\text { EUR } 380 / \mathrm{t} \\
\text { charcoal }\end{array}$ \\
\hline Yields reported & & Char: $30-35$ wt. $\%$ & $\begin{array}{l}\text { Char: } 30-33 \text { wt. } \% \\
\text { Pyroligneous acid: } \\
20-25 \%\end{array}$ & Char: 33 wt. $\%{ }^{112}$ \\
\hline
\end{tabular}


The Wagon Retort: These retorts consist of the following components: (a) a steel horizontal carbonizing chamber fitted with either a fixed cover at one end and a door at the other, or doors at both ends ${ }^{4}$. One or two vapor outlets provided on the side, top, or at one end of the chamber and a rail-track for running retort cars through, (b) a furnace for the heating process, (c) a condenser connected to the retort, (d) a steel chamber with a door at each end for cooling char placed in front of the retort and fitted with a similar rail-track, (e) a section of rail that connects the retort with the char cooler that can be moved as needed, (f) mechanical equipment for moving the cars, and $(\mathrm{g})$ retort-cars. A length of 8 to $9 \mathrm{~m}$ with a diameter up to $2.5 \mathrm{~m}$ is standard for retorts ${ }^{113}$. Retorts usually require gradual cooling of the carbonization products, generally by heat release to the surroundings at room temperature ${ }^{2}$. Compared to other methods, the wagon retort required a substantial amount of manpower ${ }^{5,114}$. This retort commonly used raw material made up of round wood and split round wood with an average length between 1.0 and $1.2 \mathrm{~m}$. A limited quantity of shorter pieces was also charged ${ }^{5,114}$. These reactors were able to produce charcoal with efficiencies up to $36 \%$, tar and oils with efficiency varying from 5 to $20 \%$, crude pyroligneous water varying from 30 to $50 \%$, and non-condensable gases varying from 20 to $30 \%$, depending on the composition of $\operatorname{wood}^{4,8}$. According to $\mathrm{Klar}^{4}$, these units were able to obtain between 2.3 and 10.5 wt. \% of acetate of lime (80\% purity), between 0.6 and 2.5 wt. \% crude naphtha, between 5 and 20 wt. \% tars, and between 0.4 and 8 wt. \% pine-oil. Charcoal was mainly used in the iron industry. Burning of gases and tar in boilers was a common practice . $^{8}$

A wagon retort system was recently in operation by Impianti Trattamento Biomasse (an Italian company). In 2010, this company had plants in Milazzo and Mortera (Italy) producing up to $6,000 \mathrm{t} / \mathrm{y}$ of charcoal $^{115}$. The process was called O.E.T. Calusco (former Carbolisi) but it does not seem in operation currently ${ }^{115}$. Alterna Biocarbon, a company with head office in Prince George, $\mathrm{BC}$, Canada, recently commercialized an upgraded design of the wagon retort ${ }^{87}$ (the company is not currently in operation). The main products targeted by this company were energy pellets, activated carbon, products for mercury recovery and chars for soil applications.

The Lambiotte Retort has proven to be a successful technology for the production of char. As a result of several attempts to simplify the SIFIC process, the CISR Lambiotte Retort was 
developed (See Figure 6$)^{43}$. The pre-dried wood enters by the top of the retort through a lock controlled electronically to keep the retort always full. The retort has four zones (cooling zone, carbonization, drying and torch $)^{110}$. The charring wood section is where the wood decomposes into char, vapors and gases. Carbonization usually proceeds at a narrow temperature range (547$560{ }^{\circ} \mathrm{C}$ ). The gases released from this section are drawn upward by a fan. The energy needed for carbonization is provided by the hot flue gases coming from combustion of part of the pyrolysis vapors in an external chamber ${ }^{5,93}$. Once the char is discharged, it is loaded on the converter plenum and carried away for storing. Since the lower segment of the retort acts as the first step in the cooling process, there is no need for separating char in the cooler ${ }^{5}$. The surplus combustible vapors can easily be used for steam or electricity generation (Table 2). These plants have been running commercially for several years. Balt Carbon Ltd. is the supplier of Lambiotte retorts for Russia and other East European and Central Asian Countries. The company has built a 2,000 t charcoal per year unit in Kaplava (Eastern Latvia) and an 8,000 t charcoal per year in Ugale (Western Latvia) ${ }^{27}$. Char Solutions Inc (http://www.biocharsolutions.com/), from Colorado, has built a reactor using similar principles (continuous downdraft pyrolysis reactor) but using chips or pellets. This system is a mobile downdraft auto-thermal gasifier able to convert up to $225 \mathrm{~kg} / \mathrm{h}$ of biomass into synthesis gas and char. The main advantages of the Lambiotte system compared with other retorts are: (1) high labor efficiency due to high level of automation, (2) higher charcoal yield, (3) good product quality, (4) it is possible to use the vapors produced for cogeneration $^{27}$. A disadvantage of the system is its sensitivity to biomass moisture content. Biomass with high moisture content reduces the capacity and in some cases may it require burning auxiliary (oil) fuel. Attrition with the consequent production of fines happens due to the vertical movement of the load. These retorts are also prone to corrosion by acetic acid ${ }^{27}$.

The operation of the Lurgi reactor is similar to the Lambiotte reactor. The Lurgi reactor (Figure 5) also has an upper carbonization zone and a lower cooling zone, each one with its own recycling gases ${ }^{43,111}$. The reactor has an air-lock hopper fed with a skip hoist that elevates dry wood blocks to the top of the reactor ${ }^{111}$. The combustion of pyrolytic vapors and gases in a staged external incinerator provides the heat for carbonization. In the first stage, the retort gas is burnt at near stoichiometric conditions. In the second stage, more air is added to ensure complete 
combustion before releasing to the atmosphere. Up to $6,000 \mathrm{Nm}^{3} / \mathrm{h}$ of gas at $600{ }^{\circ} \mathrm{C}$ is used for heating the retort ${ }^{111}$. The largest Lurgi charcoal plant forms part of the Silicon Metal Complex (SIMCOA) in Bunbury, (http://simcoa.com.au), Western Australia, and produces 27,000 t of charcoal every year in two retorts from local hardwood $43,111$.

The Carbo Twin Retort was initially developed in the 1990's in the Netherlands. The twin system was formed by two retorts placed in an insulated oven, with a monorail and overhead crane that enables the placement of retort vessels into and out the carbonization unit. The pyrolysis vapors released by the pyrolysis reactions taking place inside the vessel are combusted outside to provide the heat supply needed for heating up the system ${ }^{112}$. The system is equipped with an internal afterburner furnace with an excess of air to burn all the organic compounds ${ }^{27}$. One of the main advantages of this system is the low labor requirements: one worker per shift can operate (load and discharge) and supervise a battery of ten twin retorts ${ }^{27}$. Other advantages of this system are: high energy efficiency, high char yield, superior product quality, straight forward operation, easy scaling up with modular designs, low emissions, flexible operation and control, and continuous operation ${ }^{112}$. Carbo Twin Retorts have been installed in Almelo (The Netherlands), Parnu (Estonia), Manso Amenfi (Ghana) and Hailin (China) ${ }^{27}$. Similar twin reactor concepts have been developed also in The Netherlands by VMR Systems ${ }^{43}$, Charbon Engineering and Clean Fuels BV and also in Portugal by Ibero Massa Florestal.

Other important retorts not reviewed in detail in this section are: the Reichert Converter ${ }^{5,114}$, the Rima Container Kiln $(R C K)^{93}$, and the CML France Batteries ${ }^{43,93}$, Although not commercialized, the innovative concept of the Flash Carbonization process developed by Antal ${ }^{7}$ (in situ partial burning of the pyrolysis vapors inside the reactor with air at high pressure) is worth mentioning.

\section{Converters (also known as intermediary pyrolysis reactors)}

The carbonization techniques described in the previous section are used for logs and are not suitable for the small particles and chips found in agricultural and forest logging residues. If one of the large kilns is charged with small waste particles such as sawdust, the particles will tend to 
pack much more tightly, thus promoting insufficient penetration of gases unless the cargo is continuously rotated or moved ${ }^{4,5}$. This section reviews reactors able to handle chips and pellets, as well as deliberately crushed or chopped material such as sugarcane bagasse, bark, twiglets, olive stones or coconut shells. The reactors herein reviewed are: the Herreshoff furnaces, rotary drums, auger reactors, paddle kiln and moving beds (Figure 6). The main operational features of these reactors are shown in Table 3.

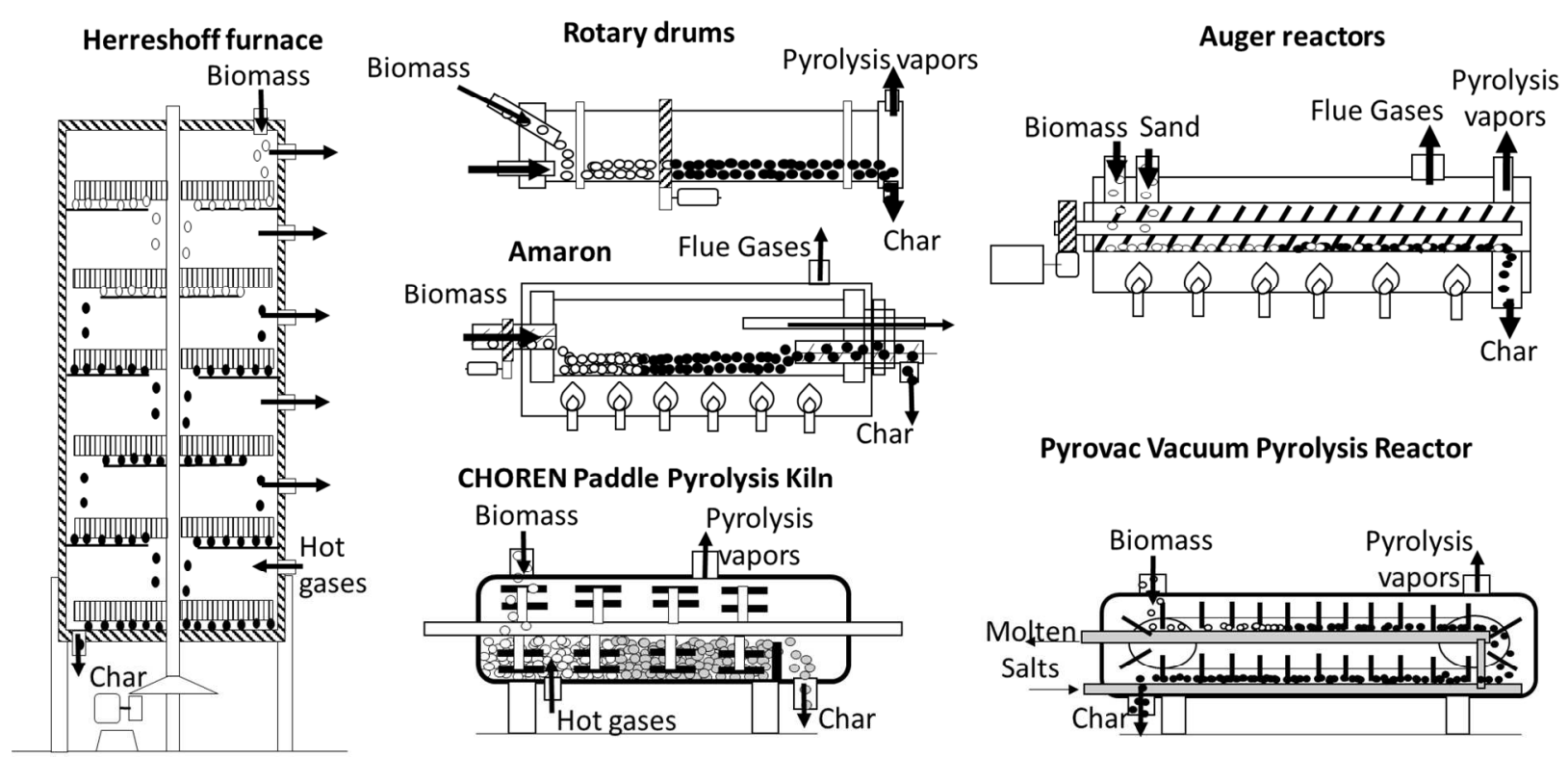

Figure 6. Scheme of common converters for processing wood chips and other small biomass particles (Adapted from: ${ }^{5,76,88,116}$ ) 
Table 3. Characteristics of converters for wood chips processing.

\begin{tabular}{|c|c|c|c|c|c|}
\hline & $\begin{array}{l}\text { Herreshoff } \\
\text { furnace }\end{array}$ & Rotary drums & Auger reactor & $\begin{array}{l}\text { Moving } \\
\text { agitated bed }\end{array}$ & $\begin{array}{l}\text { Paddle } \\
\text { pyrolysis kiln }\end{array}$ \\
\hline $\begin{array}{l}\text { Final product } \\
\text { targeted }\end{array}$ & \multicolumn{5}{|c|}{ Char/bio-oil/heat } \\
\hline $\begin{array}{l}\text { Heat transfer rate } \\
\text { achieved }\end{array}$ & \multicolumn{5}{|c|}{ Commonly slow/medium heating rates depending on particle size } \\
\hline Mode of operation & \multicolumn{5}{|c|}{ Continuous } \\
\hline Capacity & Up to $96 \mathrm{t} / \mathrm{d}$ & Up to $288 \mathrm{t} / \mathrm{d}$ & Up to $50 \mathrm{t} / \mathrm{d}^{42}$ & $84 \mathrm{t} / \mathrm{d}^{16}$ & - \\
\hline Heating method & $\begin{array}{l}\text { Direct contact } \\
\text { with hot gases }\end{array}$ & $\begin{array}{l}\text { Direct contact } \\
\text { with hot gases } \\
\text { or indirect } \\
\text { heating }\end{array}$ & $\begin{array}{l}\text { Direct contact with } \\
\text { hot gases/using a } \\
\text { hot heat carrier/ } \\
\text { indirect heating }\end{array}$ & \multicolumn{2}{|c|}{ Indirect heating } \\
\hline $\begin{array}{l}\text { Construction } \\
\text { materials }\end{array}$ & \multicolumn{5}{|c|}{ Metal } \\
\hline Portability & Stationary & $\begin{array}{c}\text { Stationary/Port } \\
\text { able }\end{array}$ & Stationary/Portable & \multicolumn{2}{|c|}{ Stationary } \\
\hline Reactor Position & \multirow{2}{*}{\multicolumn{5}{|c|}{$\begin{array}{l}\text { Horizontal } \\
\text { particles }\end{array}$}} \\
\hline Raw material used & & & & & \\
\hline $\begin{array}{l}\text { Loading and } \\
\text { discharge methods }\end{array}$ & \multicolumn{5}{|c|}{ Mechanical } \\
\hline Size of the reactor & Large & $\begin{array}{c}\text { Large/Medium } \\
\text { /Small }\end{array}$ & Small/Medium & $\begin{array}{l}\text { Medium/ } \\
\text { Large }\end{array}$ & $\begin{array}{c}\text { Small/Mediu } \\
\mathrm{m}\end{array}$ \\
\hline $\begin{array}{l}\text { Charge ignition } \\
\text { method }\end{array}$ & $\begin{array}{l}\text { Combustion of } \\
\text { pyrolysis gases } \\
\text { and/or of } \\
\text { auxiliary fuels }\end{array}$ & \multicolumn{2}{|c|}{$\begin{array}{l}\text { Combustion of auxiliary fuels and } \\
\text { direct or indirect contact of } \\
\text { combustion gases }\end{array}$} & $\begin{array}{l}\text { External oven } \\
\text { heating a hot } \\
\text { sand heat } \\
\text { carrier }\end{array}$ & $\begin{array}{c}\text { External } \\
\text { heater }\end{array}$ \\
\hline Process control & \multicolumn{5}{|c|}{ Direct measurement of temperature } \\
\hline Pressure & \multicolumn{3}{|c|}{ Atmospheric/Vacuum } & $\begin{array}{l}\text { Atmospheric / } \\
\text { Vacuum }\end{array}$ & Atmospheric \\
\hline Yield of carbon & $25-30$ wt. $\%{ }^{87}$ & - & - & - & - \\
\hline $\begin{array}{l}\text { Pretreatment } \\
\text { needed }\end{array}$ & \multicolumn{5}{|c|}{ Ground in chips/ fine particles } \\
\hline
\end{tabular}

The Herreshoff multiple hearth furnace was patented in 1921 by R.D. Pike. It consists of 4-10 circular hearths or plates located one above another inside a refractory lined steel shell ${ }^{27}$. A vertical rotating shaft (1-2 rpm) with radial arms located in the center of the shell moves the feed from the top of the hearth to the bottom using a spiral of teeth across each hearth. The shaft in the center rotates at 1-2 rpm. This converter was designed for converting raw materials in the form of sawdust, shavings, or milled wood and bark into charcoal. The system is typically heated up to $500-600{ }^{\circ} \mathrm{C}$ using external gas or oil burners ${ }^{27}$. The yield of dry char for this process is about $25 \mathrm{wt} . \%$. Automatic oxygen monitoring is used to minimize power draw and fuel demand. The first carbonization Herreshoff furnace was used in 1984, and by 1985 there were about 16 Herreshoff furnaces in use in the South of US, producing over half of the total char produced 
from wood and bark $^{27}$. This type of reactor has also been used in vacuum conditions ${ }^{117,} 118$. Currently, a mobile Herreshoff pyrolysis reactor is commercialized by BIG Char, a company with headquarters in Queensland, Australia. This company is commercializing a patented mobile multiple heart furnace, producing char and heat with capacities up to $1 \mathrm{t} / \mathrm{h}$ of biomass. The char produced is available in a briquetted form (http://www.bigchar.com.au). The major advantage of a Herreshoff furnace is its ability to efficiently and flexibly use fine-grained materials of little economic value. One disadvantage is the need for briquetting of charcoal powder before it can be commercialized. The capital cost is high.

The rotary drum reactor is a very reliable system for carbonizing biomass. Figure 6 presents the two main types of rotary drum designs (directly heated and indirectly heated). The residence time of the biomass particles in these systems are controlled by the angle of the drum and the rotation speed. A converter of this type consists of: (1) an internal concentric steel tube and a cylindrical internally insulated mantle that makes up the rotary part. A sequence of radial steel fins is supported by the mantle which has a solid connection to the steel tube, (2) the solid and gaseous products are charged and discharged by two fixed parts at the end of the rotary. This furnace provides the heat required for the carbonization process by burning gases and pyrolysis vapors. Table 4 shows the yield of liquid, char and gases reported for tests with rotary drums. This type of reactor is able to achieve a good balance between oil (between 37 and 62 wt. \% of liquid product) and char yield (19-38 wt. \%). 
The European Union ${ }^{119}$ and Japan $^{120}$ have extensively used these reactors for tires, sewage sludge, municipal solid waste, and plastics. Examples of these systems are: a $2.2 \mathrm{MW}_{\text {el }}$ pyrolysis plant operating since 1983 in Burgau-Unterknöringen, Germany, a 100,000 t/year pyrolysis plant at the VEW Energie AG (VEW) power station Westfalen in Hamm-Uentrop, Germany, and other systems that combine gasification with pyrolysis or pyrolysis with combustion ${ }^{119}$. Specific concepts of interest are: the ConTherm ${ }^{\circledR}$ technology by RWE Energie AG (RWE), the Serpac technology, the EDDITh process, The PYROPLEQ ${ }^{\circledR}$ process, Gibros PEC Process or PKA technology, SIEMENS Schwel-Brenn technology, THERMOSELECT process ${ }^{119}$. Most of those reactors could be easily adapted to work with biomass.

In 2009 Amaron Energy designed, constructed and began testing a unique indirectly-heated rotary kiln for pyrolysis of biomass to produce bio-oil and char ${ }^{121,122}$. Amaron has achieved char yields and bio oil yields close to those from fast pyrolysis fluid beds (Figure 6). The Amaron rotary reactor consists of: (1) a cylindrical reaction section heated by multiple high intensity gaseous fueled burners located and controlled to optimize heat transfer into the materials being heated, (2) a feed section with an auger arrangement that suppresses heating of the material until the particles reach the area where optimized heat transfer begins, (3) a withdrawal section with a char outlet below the end of the rotating reaction section, (4) a stationary end closure supporting a withdrawal pipe for vapors and gases. The vapors are condensed in multiple units designed to operate without problems caused by condensation of tars in the interconnecting piping.

Table 4. Yield of products obtained from rotary kilns

\begin{tabular}{|l|c|c|c|c|c|c|}
\hline Biomass specie and reactor & Capacity & $\mathrm{T}\left({ }^{\circ} \mathrm{C}\right)$ & $\begin{array}{c}\text { Char (wt. } \\
\%)\end{array}$ & $\begin{array}{c}\text { Bio-oil (wt. } \\
\%)\end{array}$ & $\begin{array}{c}\text { Gas } \\
(\text { wt. \%) }\end{array}$ & References \\
\hline Olive stones & & 500 & 26 & 38 & 35 & {$[123]$} \\
\hline Pinon-Juniper wood & $0.5 \mathrm{t} / \mathrm{h}$ & 500 & 30 & 59 & 11 & {$[122]$} \\
\hline Black liquor & $0.5 \mathrm{t} / \mathrm{h}$ & 500 & 38 & 37 & 25 & {$[122]$} \\
\hline Fir pellets & $0.5 \mathrm{t} / \mathrm{h}$ & 500 & 23 & 62 & 16 & {$[122]$} \\
\hline Fir fines & $0.5 \mathrm{t} / \mathrm{h}$ & 500 & 19 & 59 & 22 & {$[122]$} \\
\hline Lemna & $0.5 \mathrm{t} / \mathrm{h}$ & 500 & 28 & 44 & 28 & {$[122]$} \\
\hline Pine shredded & $0.5 \mathrm{t} / \mathrm{h}$ & 500 & 30 & 58 & 12 & {$[122]$} \\
\hline Pine bark & $0.5 \mathrm{t} / \mathrm{h}$ & 500 & 34 & 36 & 30 & {$[122]$} \\
\hline Aspen & $0.5 \mathrm{t} / \mathrm{h}$ & 500 & 28 & 43 & 29 & {$[122]$} \\
\hline
\end{tabular}


The auger reactor is typically fed at one end through a hopper or a feeding screw ${ }^{116,124}$. A screw then gradually carries the biomass to the hot zone of the reactor where it is carbonized, and the gases and vapors are extracted and led to a condenser ${ }^{46}$. The residence time of the hot vapors in these reactors can vary, in average from 5 to $30 \mathrm{~s}^{16}$. These reactors can be operated with and without using hot sand, steel or ceramic balls as heat carriers ${ }^{124,42}$. The discharging of char and heat carriers happen by gravity ${ }^{94}$. Table 5 shows the yield of products obtained under different operational conditions using auger pyrolysis reactors. Experimental studies with woody biomass show yields of char between 17 and 30 wt. $\%$ and yields of oil between 48 and 62 wt. $\%{ }^{42}$. The bio-oil yield is slightly lower than that of fluidized bed reactors and contains more water 30-55 $\%{ }^{42}$. As expected, the oil yield of agricultural residues was much lower due to the high ash content of this feedstock. Although difficult to compare, it seems that the yields obtained with sand heat carrier is slightly higher than those obtained without. ABRI-Tech in Canada has sold several 1 t/day units ${ }^{42}$. Auburn University (USA), KIT (FZK) (Germany), Mississippi State University (USA), Michigan State University (USA), Texas A\&M (USA) and Washington State University (USA) ${ }^{61}$ have active research programs on this technology ${ }^{16}$. 
Table 5. Auger pyrolysis results

\begin{tabular}{|c|c|c|c|c|c|c|}
\hline Biomass specie & Capacity. & $\mathrm{T}\left({ }^{\circ} \mathrm{C}\right)$ & $\begin{array}{c}\text { Char } \\
\text { (wt. \%) }\end{array}$ & $\begin{array}{l}\text { Bio-oil } \\
\text { (wt. \%) }\end{array}$ & $\begin{array}{c}\text { Gas } \\
\text { (wt.\%) }\end{array}$ & Reference \\
\hline \multicolumn{7}{|c|}{ Without heat carrier } \\
\hline Oak & $1 \mathrm{~kg} / \mathrm{h}$ & 450 & $18-20$ & $50-56$ & & [125] \\
\hline Pinewood sawdust & $1 \mathrm{~kg} / \mathrm{h}$ & 450 & $18-20$ & $49-55$ & & [125] \\
\hline Pinewood chips & $1.5 \mathrm{~kg} / \mathrm{h}$ & 500 & 30 & 58 & 12 & {$[61]$} \\
\hline Pinewood chips & $15 \mathrm{~kg} / \mathrm{h}$ & 500 & 20 & 57 & 25 & [126] \\
\hline Miscanthus & $7 \mathrm{~kg} / \mathrm{h}$ & 425 & & 60 & & [127] \\
\hline Pinewood sawdust & $7 \mathrm{~kg} / \mathrm{h}$ & 450 & 19 & 54 & & [128] \\
\hline Douglas fir wood & $1 \mathrm{~kg} / \mathrm{h}$ & 400 & 12 & 48 & 40 & [77] \\
\hline Corn stover & $7 \mathrm{~kg} / \mathrm{h}$ & 450 & & 35 & & [130] \\
\hline Switchgrass & $7 \mathrm{~kg} / \mathrm{h}$ & 450 & & 33 & & [130] \\
\hline Cassawa stalk & & 450 & & 32 & & [130] \\
\hline Peanut shell & & 450 & & 33 & & [130] \\
\hline Rice husk & & & & 35 & & [130] \\
\hline Rice straw & $60 \mathrm{~g} / \mathrm{h}$ & 500 & 45 & 26 & 13 & [131] \\
\hline \multicolumn{7}{|c|}{ With heat carrier } \\
\hline Eucalyptus grandis & $10 \mathrm{~kg} / \mathrm{h}$ & 500 & & 60.3 & & [129] \\
\hline Wheat straw (twin screw, Biolq) & $500 \mathrm{~kg} / \mathrm{h}$ & 500 & $23-28$ & $50-55$ & 22 & [132] \\
\hline Wheat straw (twin screw, Biolq) & $10 \mathrm{~kg} / \mathrm{h}$ & 500 & 24 & 51 & 24 & [133] \\
\hline Wheat bran (twin screw, Biolq) & $10 \mathrm{~kg} / \mathrm{h}$ & 500 & 18 & 60 & 22 & [133] \\
\hline Softwood (twin screw, Bioliq) & $10 \mathrm{~kg} / \mathrm{h}$ & 500 & 15 & 69 & 16 & [133] \\
\hline Hardwood (twin screw, Biolq) & $10 \mathrm{~kg} / \mathrm{h}$ & 500 & 15 & 66 & 18 & [133] \\
\hline
\end{tabular}

In moving agitated bed reactors biomass is conveyed by patented mixers over a horizontal surface heated by molten salts. These reactors have been used in vacuum conditions ${ }^{134,135}$. The molten salt used is a mixture of potassium nitrate, sodium nitrate, and sodium nitrite ${ }^{136}$. The size (height) of an industrial moving bed (few $\mathrm{cm}$ ) is comparable with the height of fixed bed of most of the laboratory tests (also few $\mathrm{cm}$ ). In fact, the scaling up of this reactor was typically conducted with the aid of fixed bed reactors operating in vacuum. In this section, we report results obtained with fixed bed at laboratory scale (Table 6). Bio-oil yields over 50 wt. \% are obtained with woody biomass in most vacuum tests. 
Table 6. Fixed bed reactor

\begin{tabular}{|c|c|c|c|c|c|c|}
\hline Biomass specie and reactor & Capacity & $\mathrm{T}\left({ }^{\circ} \mathrm{C}\right)$ & $\begin{array}{c}\text { Char (wt. } \\
\%)\end{array}$ & $\begin{array}{l}\text { Bio-oil } \\
\text { (wt. \%) }\end{array}$ & $\begin{array}{c}\text { Gas } \\
\text { (wt. \%) }\end{array}$ & References \\
\hline Rice husk and fixed bed & $180 \mathrm{~g}$ & $\begin{array}{c}100-500 \\
{ }^{\circ} \mathrm{C} / \mathrm{min}\end{array}$ & $42-48$ & $28-35$ & & {$[137]$} \\
\hline $\begin{array}{l}\text { Switch grass and } 100 \text { psi (fixed } \\
\text { bed) }\end{array}$ & & & 42 & 27 & 10 & [138] \\
\hline Pine chips & $1.4 \mathrm{~kg}$ & 500 & 31 & 50 & 18 & {$[60]$} \\
\hline $\begin{array}{l}\text { Hardwood rich in fiber (Aspen } \\
\text { poplar, white birch) (vacuum in } \\
\text { fixed bed) }\end{array}$ & $\begin{array}{c}4.2 \mathrm{~kg}(15 \\
\left.\mathrm{dm}^{3} \text { reactor }\right)\end{array}$ & 500 & 26 & 54 & 20 & [60] \\
\hline $\begin{array}{l}\text { Softwood bark residue (white } \\
\text { spruce, balsam fir, larch) } \\
\text { (vacuum in moving bed) }\end{array}$ & $\begin{array}{l}15 \mathrm{~kg} / \mathrm{h} \text { (total } \\
1050 \mathrm{~kg} \\
\text { pyrolyzed) }\end{array}$ & 500 & 28 & 45 & 27 & {$[60]$} \\
\hline $\begin{array}{l}\text { Sugarcane bagasse and vacuum } \\
\text { pyrolysis }\end{array}$ & $\begin{array}{l}\text { Pilot }(20 \mathrm{~kg}) \\
\text { Laboratory } \\
(80 \mathrm{~g})\end{array}$ & $\begin{array}{r}530 \\
500 \\
\end{array}$ & $\begin{array}{r}26 \\
19 \\
\end{array}$ & $\begin{array}{r}51 \\
62 \\
\end{array}$ & $\begin{array}{l}22 \\
18 \\
\end{array}$ & {$[59]$} \\
\hline Rape straw and vacuum reactor & & 500 & & 43 & & [139] \\
\hline $\begin{array}{l}\text { Palm oil decanter cake and } \\
\text { vacuum reactor }\end{array}$ & & 500 & 39 & 41 & 20 & [140] \\
\hline Rice husk and vacuum reactor & $10 \mathrm{~g}$ & 500 & 38 & 49 & 13 & [141] \\
\hline Rice straw and vacuum reactor & $10 \mathrm{~g}$ & 500 & 35 & 47 & 18 & [141] \\
\hline $\begin{array}{l}\text { Empty fruit bunch and vacuum } \\
\text { reactor }\end{array}$ & $10 \mathrm{~g}$ & 500 & 26 & 54 & 20 & [141] \\
\hline Douglas fir (fixed bed) & $800 \mathrm{mg}$ & 500 & 22 & 66 & 8 & {$[142]$} \\
\hline Pine and vacuum & $500 \mathrm{~g}$ & 500 & & 52 & 25 & [143] \\
\hline $\begin{array}{l}\text { Pine sawdust and vacuum } \\
\text { reactor }\end{array}$ & & 500 & 20 & 50 & 30 & [143] \\
\hline Red oak & $800 \mathrm{mg}$ & 500 & 24 & 67 & 8 & {$[142]$} \\
\hline $\begin{array}{l}\text { Camphorwood sawdust and } \\
\text { vacuum }\end{array}$ & & 474 & 20 & 50 & 30 & [144] \\
\hline Eucalyptus and vacuum & $10 \mathrm{~g}$ & 500 & 26 & 62 & 17 & [144] \\
\hline Teng wood and vacuum & $10 \mathrm{~g}$ & 500 & 30 & 58 & 12 & [144] \\
\hline Rubberwood and vacuum & $10 \mathrm{~g}$ & 500 & 30 & 51 & 19 & [144] \\
\hline
\end{tabular}

The Paddle Pyrolysis reactor (See Figure 6) (145 $^{14}$ characterized by the use of internal mechanisms to move and mix the biomass and thus to increase heat transfer. This kind of reactors have been used by companies such as BEST Energies, currently part of Pacific Pyrolysis Inc., (http://pacificpyrolysis.com/technology.html), and was also part of the design of Choren ${ }^{146}$.

Other important reactors in this category not included in this review are the Shelf reactors 4,46 and the Stafford-Badger retort ${ }^{10}$. The converters are the reactors with more potential for the balanced production of char and oil. However, more research is needed to understand the potential of these reactors. 


\section{Fast pyrolysis reactors for high yields of bio-oil production}

This section reviews the most common fast pyrolysis reactors (rotating cone, ablative, conical spouted bed, bubbling fluidized bed and circulating bed) (Figure 7) that have been developed intending to optimize the yields of bio-oil. There are very good literature reviews in fast pyrolysis reactors $15,16,19,136,147$. Thus, this section will only focus on recent developments. The main characteristics of the reactors studied in this section are discussed in Table 7.
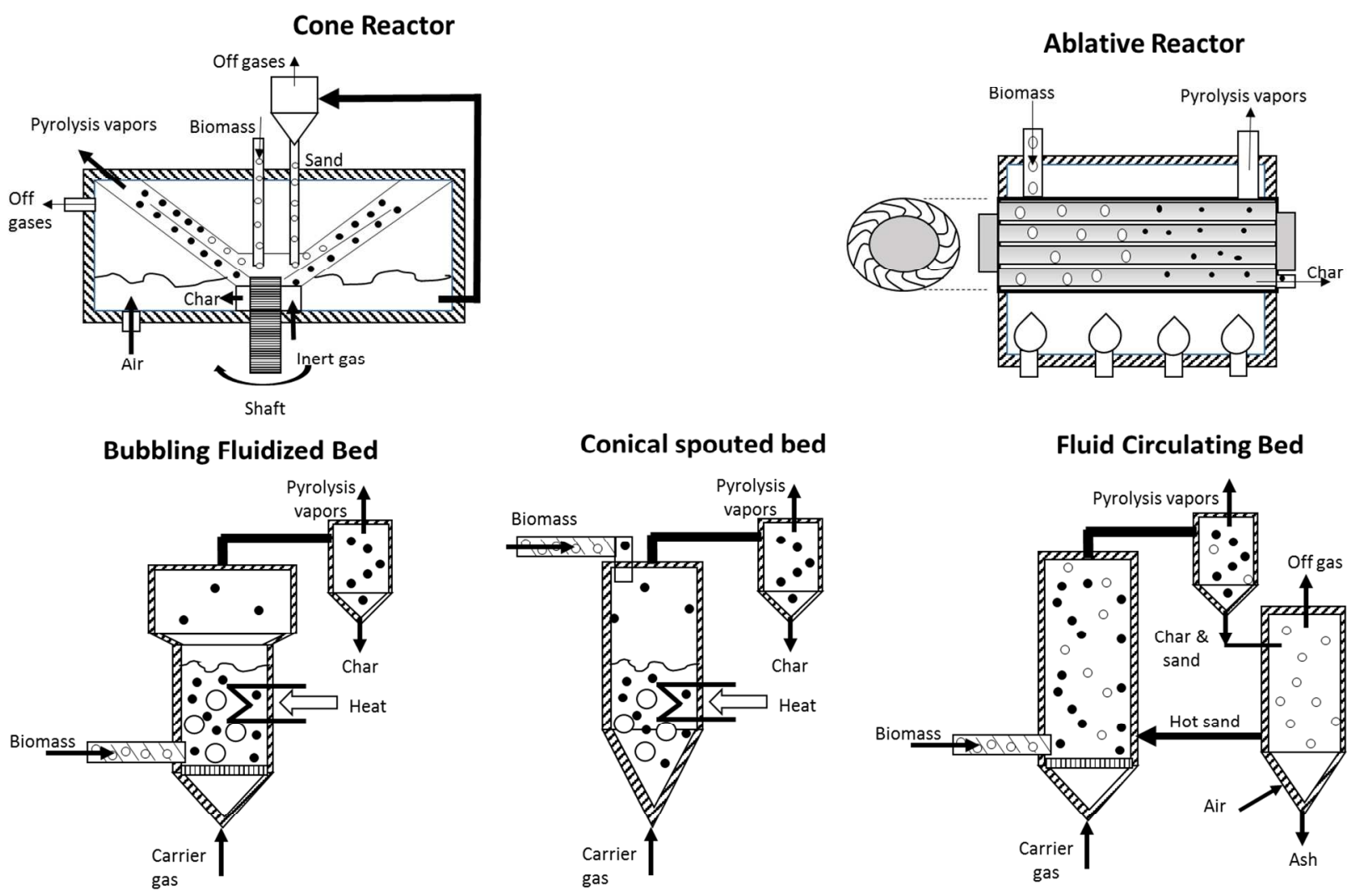

Figure 7. Schemes of Fast Pyrolysis Reactors (Adapted from ${ }^{136}$ ) 
Table 7. Characteristics of some fast pyrolysis reactors

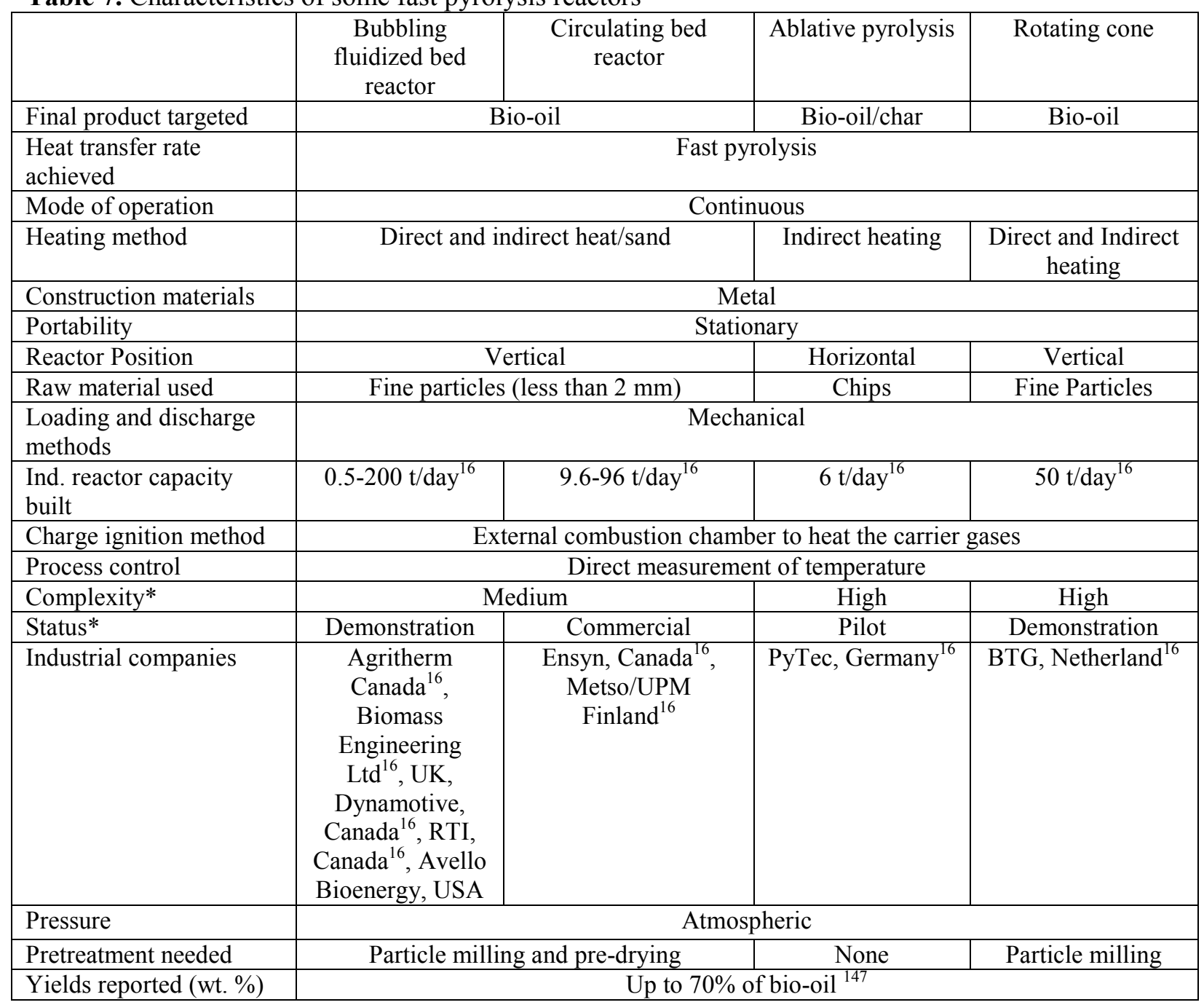

The bubbling fluidized bed reactors use a mixture of convection and conduction to transfer heat from a heat source (hot sand) to the biomass particle. Although most of the literature suggest that fast pyrolysis should be operated with particles with diameters $2-3 \mathrm{~mm}^{16}$ to obtain high liquid yields (over $65 \%$ ), the particles must be smaller (typically below $0.5 \mathrm{~mm}$ ) ${ }^{49}, 50$ to avoid the retention of aerosols inside the particle and to achieve high heat transfer rates. One of the bestknown examples of using a fluidized bed reactor was Dynamotive, company that was a result of the pioneering job conducted by the University of Waterloo ${ }^{11,12,148}$. In the design of most fluidized bed reactors in operation the char is entrained by carefully controlling the difference between the sizes and densities between biomass particles and the sand. Char particles obtained 
from the pyrolysis of raw materials with very high ash content such as, sewage sludge, usually abandons the bubbling fluidized beds by overflow. The heat used in bubbling fluidized beds is generated from the combustion of pyrolysis gases and chars and is typically transferred to the fluidized bed by heating coils and by heating the carrier gas (in industrial conditions typically a recirculated pyrolytic gas). Given the low heat transfer rates between combustion gases and the bed $\left(100-200 \mathrm{~W} / \mathrm{m}^{2} \mathrm{~K}\right)$ at least 10 to $20 \mathrm{~m}^{2}$ of surface area is required to transfer the heat required to pyrolyze $1 \mathrm{t} / \mathrm{h}$ of biomass. These heat transfer surfaces are very susceptible to attrition from the sand ${ }^{136}$. Several main features of this type of reactors are: the ability to accurately control temperature, the use of entrainment for the separation of the char, the use of cyclone separation, the easy scaling, the technology is well known and understood, small particlesare required, and there must be a large scale heat transfer to the bed. Dynamotive developed bench-scale plants, a 15 t/day pilot plant, a 130 t/day plant in West Lorne, and a 200 t/day plant in Guelph, Ontario, Canada $^{149}$ that are currently not operating. Tables 8-10 show the yield of products obtained from the pyrolysis of grass and agricultural residues, softwood, and hardwood species in fluidized beds. When processing grasses and other agricultural wastes the conversion yield to liquid biooil, solid char and non-condensable gas are in the ranges of 35-68.7 wt. \%, 12.9-45.7 wt. \% and 3-25.7 wt. \%, respectively, on an as fed basis (Table 8). This broad range of values is mostly due to the wide range of ash contents in these materials. When processing of softwoods result in 5978.1 wt. \% bio-oil, 10-15.7 wt. \% char and 7.8-28 wt. \% non-condensable gas. Comparable yields were also obtained for hardwood species (char: 9.8-20.7 wt. \%, bio-oil: 59-77 wt. \%, gases: 9.3-24.6 wt. \%). Lower oil yields (35-73 wt. \%) and higher char yields (13.4-45.7 wt. \%) are obtained with some grasses, likely due to higher ash content in some of these materials. 
Table 8. Pyrolysis of grasses and agricultural residues using fluidized bed reactors.

\begin{tabular}{|l|c|c|c|c|c|c|}
\hline Biomass specie & Capacity & $\mathrm{T}\left({ }^{\circ} \mathrm{C}\right)$ & $\begin{array}{c}\text { Char }(\mathrm{wt} \\
\%\end{array}$ & $\begin{array}{c}\text { Bio-oil } \\
(\text { wt } \%)\end{array}$ & $\begin{array}{c}\text { Gas } \\
\text { (wt. \%) }\end{array}$ & Reference \\
\hline Corn stover & $100 \mathrm{~g} / \mathrm{h}$ & 450 & 46 & 35 & 11 & {$[12]$} \\
\hline Corn stover & $100 \mathrm{~g} / \mathrm{h}$ & 550 & 34 & 50 & 14 & {$[12]$} \\
\hline Corn stover & $100 \mathrm{~g} / \mathrm{h}$ & 600 & 28 & 50 & 13 & {$[12]$} \\
\hline Rice husk & $120 \mathrm{~kg} / \mathrm{h}$ & 475 & - & 50 & & {$[150]$} \\
\hline Rice husk & $<150 \mathrm{~kg} / \mathrm{h}$ & 450 & 30 & 50 & 20 & {$[151]$} \\
\hline Rice husk & $7.32 \mathrm{~kg} / \mathrm{h}$ & 450 & 29 & 56 & 15 & {$[152]$} \\
\hline Rice husk & $60 \mathrm{~g} / \mathrm{h}$ & 500 & & 55 & & {$[153]$} \\
\hline Rice straw & $300 \mathrm{~g} / \mathrm{h}$ & 500 & 27 & 43 & 23 & {$[131]$} \\
\hline Rice straw & $60 \mathrm{~g} / \mathrm{h}$ & 500 & 31 & 53 & 15 & {$[153]$} \\
\hline Corn cob & $60 \mathrm{~g} / \mathrm{h}$ & 500 & 20 & 62 & 17 & {$[153]$} \\
\hline Sugarcane bagasse & $60 \mathrm{~g} / \mathrm{h}$ & 500 & & 67 & & {$[153]$} \\
\hline Sugarcane bagasse & $2-5.3 \mathrm{~kg} / \mathrm{h}$ & 500 & 23 & 73 & 4 & {$[154]$} \\
\hline Suggarcane bagasse & $100 \mathrm{~g} / \mathrm{h}$ & 510 & 19 & 69 & 12 & {$[148]$} \\
\hline Barley straw & $1 \mathrm{~kg} / \mathrm{h}$ & 525 & & 54 & & {$[155]$} \\
\hline Timothy & $1 \mathrm{~kg} / \mathrm{h}$ & 525 & & 61 & & {$[155]$} \\
\hline Switchgrass & $1 \mathrm{~kg} / \mathrm{h}$ & 510 & 19 & 60 & 16 & {$[156]$} \\
\hline Switchgrass & $2.5 \mathrm{~kg} / \mathrm{h}$ & 480 & 13 & 61 & 11 & {$[157]$} \\
\hline Switchgrass & & & 20 & 58 & & {$[158]$} \\
\hline Miscanthus & $1 \mathrm{~kg} / \mathrm{h}$ & 505 & 29 & 51 & 12 & {$[156]$} \\
\hline Wheat straw & $1 \mathrm{~kg} / \mathrm{h}$ & 525 & 27 & 38 & 26 & {$[156]$} \\
\hline Wheat straw & $1.5 \mathrm{~kg} / \mathrm{h}$ & 525 & 22 & 61 & 17 & {$[158]$} \\
\hline Wheat straw & $100 \mathrm{~g} / \mathrm{h}$ & 550 & 24 & 54 & 24 & {$[148]$} \\
\hline Wheat chaff & $100 \mathrm{~g} / \mathrm{h}$ & 515 & 18 & 67 & 16 & {$[148]$} \\
\hline Sorghum bagasse & $100 \mathrm{~g} / \mathrm{h}$ & 510 & 13 & 69 & 12 & {$[148]$} \\
\hline Sunflower hulls & $100 \mathrm{~g} / \mathrm{h}$ & 500 & 23 & 57 & 20 & {$[148]$} \\
\hline
\end{tabular}

Table 9. Pyrolysis of softwood species using fluidized bed

\begin{tabular}{|l|c|c|c|c|c|c|}
\hline Biomass specie & Capacity & $\mathrm{T}\left({ }^{\circ} \mathrm{C}\right)$ & $\begin{array}{c}\text { Char } \\
(\mathrm{wt.} \%)\end{array}$ & $\begin{array}{c}\text { Bio-oil } \\
(\mathrm{wt} . \%)\end{array}$ & $\begin{array}{c}\text { Gas } \\
(\mathrm{wt} \%)\end{array}$ & References \\
\hline $\begin{array}{l}\text { Pine-wood chip and } \\
\text { pellets }\end{array}$ & $1 \mathrm{~kg} / \mathrm{h}$ & 530 & 10 & 59 & 28 & {$[159]$} \\
\hline $\begin{array}{l}\text { Pitch pine (debarked, dp }< \\
5 \mathrm{~mm} \text { ) }\end{array}$ & $\begin{array}{c}\text { Non-cont. } \\
\text { feed }\end{array}$ & 500 & 16 & 64 & 21 & {$[160]$} \\
\hline Pine sawdust & $1 \mathrm{~kg} / \mathrm{h}$ & 525 & & $67-71$ & & {$[155]$} \\
\hline Douglass - fir & $220 \mathrm{~g} / \mathrm{h}$ & 500 & & 52 & & {$[161]$} \\
\hline Douglass - fir & $3-5 \mathrm{~kg} / \mathrm{h}$ & 480 & 12 & 64 & 24 & {$[162]$} \\
\hline Spruce & $300 \mathrm{~g} / \mathrm{h}$ & $465-470$ & 14 & 61 & 27 & {$[163]$} \\
\hline $\begin{array}{l}\text { Japanese Cedar } \\
\text { (debarked, dp }<0.5 \mathrm{~mm})\end{array}$ & $\begin{array}{c}\text { Non-cont. } \\
\text { feed }\end{array}$ & 500 & 13 & 66 & 22 & {$[160]$} \\
\hline Pine sawdust & $1 \mathrm{~kg} / \mathrm{h}$ & 525 & & $67-71$ & & {$[155]$} \\
\hline Spruce sawdust & $100 \mathrm{~g} / \mathrm{h}$ & 500 & 12 & 78 & 8 & {$[148]$} \\
\hline
\end{tabular}


Table 10. Pyrolysis of hardwood species using fluidized bed reactors

\begin{tabular}{|l|c|c|c|c|c|c|}
\hline Biomass specie & Capacity & $\mathrm{T}\left({ }^{\circ} \mathrm{C}\right)$ & $\begin{array}{c}\text { Char } \\
(\text { wt. \%) }\end{array}$ & $\begin{array}{c}\text { Bio-oil } \\
(\text { wt. \%) }\end{array}$ & $\begin{array}{c}\text { Gas } \\
(\text { wt. \%) }\end{array}$ & References \\
\hline Red oak & $6 \mathrm{~kg} / \mathrm{h}$ & 400 & 21 & 67 & 13 & {$[164]$} \\
\hline Red oak & $6 \mathrm{~kg} / \mathrm{h}$ & 500 & 19 & 63 & 18 & {$[164]$} \\
\hline Red oak & $1.5 \mathrm{~kg} / \mathrm{h}$ & $450-500$ & 25 & 62 & 13 & {$[165]$} \\
\hline Eucalyptus grandis & $700 \mathrm{~g} / \mathrm{h}$ & 500 & & 69 & & {$[166]$} \\
\hline Eucalyptus grandis & $0.1 \mathrm{~kg} / \mathrm{h}$ & 500 & & 69 & & {$[129]$} \\
\hline Eucalyptus grandis woodchips & $1 \mathrm{~kg} / \mathrm{h}$ & 500 & & 62 & & {$[129]$} \\
\hline Eucalyptus (debarked) & $0.85 \mathrm{~kg} / \mathrm{h}$ & 500 & & 62 & & {$[167]$} \\
\hline Eucalyptus loxophleba wood & $0.15 \mathrm{~kg} / \mathrm{h}$ & 500 & 14 & 61 & 25 & {$[160]$} \\
\hline Eucalyptus loxophleba wood & $2 \mathrm{~kg} / \mathrm{h}$ & 500 & 14 & 62 & 12 & {$[49]$} \\
\hline Eucalyptus wood & $1 \mathrm{~kg} / \mathrm{h}$ & 450 & 17 & 64 & & {$[168]$} \\
\hline Eucalyptus grandis woodchips & $1 \mathrm{~kg} / \mathrm{h}$ & 500 & 18 & 59 & 23 & {$[169]$} \\
\hline Eucalyptus loxophleba wood & $0.1 \mathrm{~kg} / \mathrm{h}$ & 450 & 14 & 71 & 14 & {$[170]$} \\
\hline Beech & $1 \mathrm{~kg} / \mathrm{h}$ & 510 & 13 & 72 & 9 & {$[171]$} \\
\hline Beech & $1 \mathrm{~kg} / \mathrm{h}$ & 512 & 13 & 67 & 12 & {$[156]$} \\
\hline Beech & $300 \mathrm{~g} / \mathrm{h}$ & $465-470$ & 10 & 70 & 23 & {$[163]$} \\
\hline Beech & $1 \mathrm{~kg} / \mathrm{h}$ & 500 & 10 & 71 & 15 & {$[50,62]$} \\
\hline Poplar sawdust & $100 \mathrm{~g} / \mathrm{h}$ & 504 & 12 & 77 & 11 & {$[148]$} \\
\hline
\end{tabular}

$10 \mathrm{t} /$ day mobile pyrolysis units with a fluidized bed reactor have been developed by Agritherm at the University of Western Ontario (http://agri-therm.com) ${ }^{16,42}$. An important feature of the design proposed by this company is a compact design in which the pyrolysis reactor is built using an annulus with a burner at the core providing the energy needed for the pyrolysis process. Avello Bioenergy in the State of Iowa (US) is another company commercializing fast pyrolysis technologies (http://www.avellobioenergy.com). This company specializes in the development of fractionation strategies to obtain different products from bio-oils. Bioware is a Brazilian company commercializing auto-thermal fluidized bed reactors ${ }^{172}$ to produce bio-oil, char and phenolic resins (https://www.bioware.com.br). Nettenergy BV is a private company from the Netherlands (http://www.nettenergy.com/index.php/en/) that built a $100 \mathrm{~kg} / \mathrm{h}$ mobile unit with a unique multi-stage compact separation design ${ }^{42}$.

Circulating fluidized beds: Research performed by the University of Western Ontario in the late 1970s and early 1980s spawned the Rapid Thermal Processing (RTP) ${ }^{\text {TM }}$ technology commercialized and developed by Ensyn. Before feeding this system's reactor, the biomass is comminuted to approximately $6 \mathrm{~mm}$, and then dried to a moisture content of $10 \%$ or less. The hot recirculated biomass and sand enter in an up-flowing transported bed reactor. Once the 
products have passed through two cyclones that separate both solids from the produced vapors, they experience a rapid cooling and quenching in multiple stages ${ }^{14}$. The residence time of the solids and vapors in these reactors is almost the same ${ }^{16}$. The recirculation of gases from secondary char combustion is the main heat source ${ }^{16}$. RTP is the only pyrolysis technology in the world that has operated on a long-term commercial basis (http://www.ensyn.com, https://www.envergenttech.com). Larger scale units include: ENEL plant build by Ensyn in Italy (15.6 t/day), several $40 \mathrm{t}$ /day units at Red Arrow (USA) operating for the production of smoke aromas and the Ensyn 50 t/day unit at their R\&D center in Renfrew Canada ${ }^{16}$. Some features of the transported bed reactor include: precise temperature control within the reactor, the ability to use large size particles, suitability for very large throughputs, and well understood technology ${ }^{16}$. Some of the main disadvantages of these technologies are: (1) use of large volumes of inert carrier gases causes a dilution of the pyrolytic gases making bio-oil recovery very difficult (2) many fast pyrolysis reactors use sand as a heat carrier, (3) complex hydrodynamics, (4) high velocities lead to higher levels of attrition, and the separation of the char and the sand from the vapors with a "cyclone", (5) careful control is needed for the closely integrated combustion, and a large scale heat transfer to the bed is required (6) Char and sand attrition is an important issue. Table 11 shows the yield of bio-oil reported in the literature for different feedstocks. Bio-oil yields between 54 and 71 wt. \% have been reported.

Table 11. Pyrolysis of biomass using circulating fluidized bed reactors.

\begin{tabular}{|l|c|c|c|c|}
\hline Biomass specie & Capacity & $\mathrm{T}\left({ }^{\circ} \mathrm{C}\right)$ & $\begin{array}{c}\text { Bio-oil } \\
(\text { wt. \%) }\end{array}$ & References \\
\hline Timothy & $20 \mathrm{~kg} / \mathrm{h}$ & 520 & 54 & {$[155]$} \\
\hline Rapeseed straw & $20 \mathrm{~kg} / \mathrm{h}$ & 520 & 60 & {$[155]$} \\
\hline Pine saw dust & $20 \mathrm{~kg} / \mathrm{h}$ & 520 & 74 & {$[155]$} \\
\hline Green forest residue $(86 \%$ spruce, $9 \%$ pine, $5 \%$ birch) & $20 \mathrm{~kg} / \mathrm{h}$ & 520 & 64 & {$[155]$} \\
\hline Brown forest residue $(80 \%$ spruce, $10 \%$ pine, $10 \%$ birch) & $20 \mathrm{~kg} / \mathrm{h}$ & 520 & 58 & {$[155]$} \\
\hline Eucalyptus chips & $20 \mathrm{~kg} / \mathrm{h}$ & 520 & 71 & {$[155]$} \\
\hline
\end{tabular}

A similar technology, with the use of catalysts instead of inert sand is being developed by KIOR, now Inaeris Tech (http://www.inaeristech.com/), a company located in Houston, Texas. The company uses a proprietary catalyst system to produce a deoxygenated bio-oil in a Fluid Catalytic Cracking (FCC) reactor. Metso, UPM and Fortum constructed and has operated since 
2013 a $400 \mathrm{~kg} / \mathrm{h}$ circulating bed pyrolysis reactor coupled with a condensation system in Joensuu (Finland). The bio-oil produced is combusted in a fluidized bed power boiler ${ }^{16}$. CPERI (Greece), Guangzhou Inst. Energy Conversion (China), U. Birmingham and U. Nottingham (UK) and VTT (Filand) have active research programs on this technology ${ }^{16}$.

Rotating Cone: This technology was developed by the University of Twente and is commercialized by BTG-BTL (Biomass Technology Group-Biomass to Liquid, Netherlands) (http://www.btgworld.com/en/) ${ }^{16}$. The centrifugal force effectively develops a transported bed without the need for large volumes of carrier gas ${ }^{16}$. The hot sand and the biomass are transported up in a conical bed by the centrifugal forces created by rotation of the cone ${ }^{16}$. This process has been successfully applied in Malaysia for the conversion of empty fruit bunches from palm oil trees in a demonstration plant of $50 \mathrm{t} /$ day capacity ${ }^{165}$. This technology has been also used by Empyro for the construction of a plant that operates from 2015 in Hengelo (The Netherlands). This plant converts $5 \mathrm{t} / \mathrm{h}$ of wood residues into pyrolysis oil, process steam and electricity. In both plants, gas and char are burned to heat the sand, which is recycled back to the pyrolysis reactor $^{16}$.

Ablative pyrolysis: This process entails a heated surface in which wood is pressed against and moved rapidly leaving an oily film that then evaporates ${ }^{16}$. Larger particles of wood can be used for this process and the limiting factor is typically the rate of heat supplied to the reactor. These reactors can process large amounts of biomass in a little volume, are compact and do not require carrier gases or recirculation $^{70,71}$. The rate of reaction is proportional to the force exerted on the biomass in contact with the wall and the available heat transfer surface ${ }^{16}$. An important feature of ablative heat transfer is that when the biomass contacts the hot solid, ablation occurs and subsequently exposes new fresh biomass to the hot surface. This, in theory, allows for no limitations in particle size. NREL (Golden, Colorado, USA) and CNRS laboratories (France) conducted most of the pioneering studies on ablative reactors ${ }^{16}$. In the $90 \mathrm{~s}, \mathrm{BBC}$ from Canada built and operated an ablative reactor with a capacity between $10-25 \mathrm{~kg} / \mathrm{h}^{136}$ (this company is not in operation today). The University of Hamburg built three plants using ablative reactors. The first plant was conceived for research and has a capacity of $20 \mathrm{~kg} / \mathrm{h}$; the second one, is a pilot 
plant of $250 \mathrm{~kg} / \mathrm{h}$ and the third is a demonstration unit with capacity of $2 \mathrm{t} / \mathrm{h}^{16,136}$. Reed and Cowdrey constructed an ablative pyrolysis reactor testing bone dry wood at a feeding rate of 0.2 $\mathrm{kg} / \mathrm{h}^{14}$. Biomass-to-oil (BTO) process was developed by PYTEC, Germany. The process is based on the ablative pyrolysis principle. Biomass wood (including chips of $60 \times 40 \times 5 \mathrm{~mm}$ ) is put in direct contact with a rotating hot metal surface that melts the wood and produces oil ${ }^{173}$. The crude bio-oil produced is combusted in a CHP unit running on a $300 \mathrm{MW}_{\mathrm{e}}$ diesel engine ${ }^{173}$. Compared with the fluidized bed, the main advantages of ablative reactors are: (1) no milling efforts needed for biomass, (2) compact design because of ideal heat transfer with high heating rates at relatively small contact surfaces, (3) energy and cost efficiency as no heating and cooling of fluidized bed is required, (4) condensation units with small volume can be installed, requiring less space and lower $\operatorname{cost}^{174}$. The main downsides are that these reactors require a heated surface area control system, operates with moving parts at high temperatures increasing their complexity, and induces an inevitable wear and tear on the moving components ${ }^{175}$. Table 12 reports the yields obtained in ablative reactors using wood and wheat straw. The yields of char, oil and gases are comparable with those obtained with similar feedstock with fluidized bed reactors. Aston University (UK), Institute of Engineering Thermophysics (Ukraine), Latvian State Institute (Latvia) and the Technical University of Denmark have active programs on this technology ${ }^{16,42}$.

Table 12. Experiences on biomass fast pyrolysis using ablative pyrolysis reactors

\begin{tabular}{|c|c|c|c|c|c|c|}
\hline Biomass specie & Capacity & $\mathrm{T}\left({ }^{\circ} \mathrm{C}\right)$ & $\begin{array}{c}\text { Char }(\text { wt. } \\
\%)\end{array}$ & $\begin{array}{c}\text { Bio-oil } \\
(\text { wt. \%) }\end{array}$ & $\begin{array}{c}\text { Gas } \\
(\text { wt. \%) }\end{array}$ & Reference \\
\hline Barley or wheat straw & $10 \mathrm{~kg} / \mathrm{h}$ & 549 & 32 & 50 & 12 & {$[176]$} \\
\hline Wheat straw & $\begin{array}{c}\text { Lab-scale pyrolysis } \\
\text { centrifuge reactor }\end{array}$ & 525 & $23-32$ & $40-47$ & $27-30$ & {$[177]$} \\
\hline Wood & $250 \mathrm{~kg} / \mathrm{h}$ & 650 & 6 & 60 & 34 & {$[174]$} \\
\hline
\end{tabular}

Spouted fluid bed reactor: The viability of the spouted bed technology for pyrolysis was studied by the Chemical Engineering Department of the University of the Basque Country (Spain). A pilot plant at Ikerlan-IK4 facility with capacity to process up to $25 \mathrm{~kg} / \mathrm{h}$ of biomass is now operational $^{16,178}$. The yield of products shown in Table 13 is comparable and even higher to those reported for fluidized bed reactors for similar feedstocks. The Anhui University of Science $\&$ Technology is also developing this technology ${ }^{16}$. 
Table 13. Biomass pyrolysis results using a conical spouted bed

\begin{tabular}{|c|c|c|c|c|c|c|}
\hline Biomass specie & Capacity & $\mathrm{T}\left({ }^{\circ} \mathrm{C}\right)$ & $\begin{array}{c}\text { Char } \\
(\text { wt.\%) }\end{array}$ & $\begin{array}{c}\text { Biooil } \\
(\text { wt.\%) }\end{array}$ & $\begin{array}{c}\text { Gas } \\
(\text { wt. \%) }\end{array}$ & Reference \\
\hline Rice husk & $60 \mathrm{~g} / \mathrm{h}$ & 450 & 26 & 70 & 4 & {$[179]$} \\
\hline $\begin{array}{c}50 \% \text { Cytisus multiflorus and } 50 \% \\
\text { Spartium junceum }\end{array}$ & $200 \mathrm{~g} / \mathrm{h}$ & 500 & 17 & 80 & 4 & {$[180]$} \\
\hline Pterospartum tridentatum & $200 \mathrm{~g} / \mathrm{h}$ & 500 & 20 & 75 & 5 & {$[180]$} \\
\hline Miscanthus & Lab-scale & 500 & 38 & 40 & 20 & {$[181]$} \\
\hline Pine saw dust & $200 \mathrm{~g} / \mathrm{h}$ & 500 & 17 & 75 & 8 & {$[182]$} \\
\hline Pine saw dust & $5 \mathrm{~kg} / \mathrm{h}$ & 480 & 14 & 73 & 13 & {$[183]$} \\
\hline Acacia dealbata (Silver wattle) & $200 \mathrm{~g} / \mathrm{h}$ & 500 & 23 & 72 & 5 & {$[180]$} \\
\hline Eucalyptus & $200 \mathrm{~g} / \mathrm{h}$ & 500 & 18 & 75 & 6 & {$[184]$} \\
\hline
\end{tabular}

\section{Microwave Pyrolysis}

There are excellent reviews on microwave pyrolysis ${ }^{44,45,185,186}$. Von Hippel developed the basic understanding of the macroscopic microwave-matter interactions ${ }^{44}$. Microwave wavelengths falls between infrared and radio regions (from 0.3 to $300 \mathrm{GHz})^{44,45}$. Heating is due to molecular friction during dipolar molecules rotation induced by the electromagnetic radiation. Conversely to conventional heating, microwave heating is a volumetric heating, so an opposite temperature gradient is established ${ }^{44}$. Tech-En Ltd in Hainault (UK) developed microwave pyrolysis in the mid-nineties ${ }^{185,187,188}$. In this process, the feedstock is thoroughly mixed with a highly microwave-adsorbent material (often char), which absorbs enough microwave energy (typically at $915 \mathrm{MHz}$ or $2.45 \mathrm{GHz})^{185}$. Although microwave penetration is typically $1-2 \mathrm{~cm}$, penetration depth varies depending on the properties of the materials and radiation frequency (oil palm fiber: $10.2 \mathrm{~cm}$ (at $5.8 \mathrm{GHz}$ ), oil palm shell: $5.5 \mathrm{~cm}(5.8 \mathrm{GHz})$, biochar: $8.5 \mathrm{~cm}(5.8 \mathrm{GHz})$, paper and cardboard: $20-60 \mathrm{~cm}(2.54 \mathrm{GHz})$, wood: $8-350 \mathrm{~cm}(2.54 \mathrm{GHz}))^{44}$. While, microwave heating favors solid phase reactions, or heterogeneous reactions, conventional heating has higher effect on gas-phase reactions ${ }^{44}$. Table 14 shows product yields obtained with these reactors. 
Table 14. Results of Biomass microwave pyrolysis.

\begin{tabular}{|c|c|c|c|c|c|c|}
\hline Biomass specie & Reactor & $\mathrm{T}\left({ }^{\circ} \mathrm{C}\right)$ & $\begin{array}{l}\text { Char } \\
\text { (wt. \%) }\end{array}$ & $\begin{array}{l}\text { Bio-oil } \\
\text { (wt. \%) }\end{array}$ & $\begin{array}{c}\text { Gas } \\
\text { (wt. \%) }\end{array}$ & Reference \\
\hline Wheat straw & $\begin{array}{c}\text { Mass: } 5-30 \mathrm{~g}, \mathrm{~N}_{2}: 3 \mathrm{~L} / \mathrm{min}, 3 \\
\mathrm{~kW} \text { at } 2.45 \mathrm{GHz}\end{array}$ & $400-600$ & & & $17-22$ & [189] \\
\hline $\begin{array}{l}\text { Larch (Lalix leptolepis } \\
\text { GORDON) Cylindrical } \\
\text { blocks (d: } 60-300 \mathrm{~mm} \text {; } \\
\text { weight: } 80-12000 \mathrm{~g} \text { ) }\end{array}$ & $\begin{array}{c}1.5-3 \mathrm{~kW} \text { at } 2.45 \mathrm{GHz}, \\
\text { exposition time: } 3-12.5 \mathrm{~min}\end{array}$ & & $18-50$ & $15-30$ & & [190] \\
\hline Microalgae & Mass:30 g, power: $0.75-2.25$ & 200 & 90 & 0 & 10 & [191] \\
\hline (Chlorella vulgaris) & $\mathrm{kW}$ at $2.45 \mathrm{GHz}, \mathrm{N}_{2}: 300$ & 600 & 30 & 36 & 34 & \\
\hline particle size $<200 \mu \mathrm{m}$ & $\begin{array}{l}\mathrm{mL} / \mathrm{min} \text {, catalysts: activated } \\
\text { carbon, } \mathrm{CaO}, \mathrm{SiC}\end{array}$ & 775 & 25 & 22 & 52 & \\
\hline $\begin{array}{l}\text { Douglas fir sawdust } \\
\text { pellet (diameter: } 6 \mathrm{~mm} \text {, } \\
\text { length: } 10 \mathrm{~mm} \text { ) }\end{array}$ & $\begin{array}{l}\text { Mass: } 400 \mathrm{~g}, 0.7 \mathrm{~kW} \text {, } \\
\text { reaction time: } 10-20 \mathrm{~min}\end{array}$ & $350-450$ & $31-61$ & $31-54$ & $8-15$ & {$[192[$} \\
\hline Sewage sludge & $\begin{array}{c}\text { Mass: } 100 \mathrm{~g}, 25 \mathrm{~g} \text { of } \\
\text { graphite }(1 \mathrm{x} 1 \mathrm{~mm}) \text { as } \\
\text { microwave absorber, } \mathrm{N}_{2:} \\
100 \mathrm{~mL} / \mathrm{min}, \text { Power } 0.4-0.6 \\
\mathrm{~kW} \text { at } 2.45 \mathrm{GHz}\end{array}$ & $490-570$ & $39-40$ & $48-50$ & $11-12$ & [193] \\
\hline Rice straw & $\begin{array}{c}\text { Mass: } 3-5 \mathrm{~g}, \mathrm{~N}_{2}: 50 \mathrm{~mL} / \mathrm{min}, \\
0.2-0.5 \mathrm{~kW}\end{array}$ & $280-500$ & & & $<70$ & [194] \\
\hline $\begin{array}{c}\text { Oil palm fiber (OPF) } \\
(0.3-0.6 \mathrm{~mm}) \text {, and oil } \\
\text { palm shell (OPS) (0.001 } \\
\text { to } 0.1 \mathrm{~m})\end{array}$ & $\begin{array}{c}\text { Ratio sample: microwave } \\
\text { absorber }(1: 0.25,1: 0.5 \text {, and } \\
1: 1) \text {, power } 0.45 \mathrm{~kW} \text { at } 2.45 \\
\text { GHz, exposure time: } 25 \mathrm{~min} \\
\end{array}$ & $\begin{array}{l}400- \\
1300\end{array}$ & $\begin{array}{c}\text { OPS } \\
45-70 \\
\text { OPF } \\
50-80 \\
\end{array}$ & $\begin{array}{l}\text { OPS } 10- \\
20 \\
\text { OPF } 5-25\end{array}$ & $\begin{array}{l}\text { OPS } 20- \\
30 \\
\text { OPF } 10- \\
28 \\
\end{array}$ & [195] \\
\hline $\begin{array}{c}\text { Microalgae } \\
(\text { Chlorella } s p)\end{array}$ & $\begin{array}{l}\text { Mass: } 30 \mathrm{~g}, 6 \mathrm{~g} \text { of char as } \\
\text { microwave absorber, } \mathrm{N}_{2} \text { : } \\
500 \mathrm{~mL} / \mathrm{min} \text {, Power } 0.5- \\
1.25 \mathrm{~kW} \text { at } 2.45 \mathrm{GHz} \\
\text { exposition time: } 20 \mathrm{~min}\end{array}$ & $460-630$ & $25-28$ & $\begin{array}{l}\text { Oil 18-28 } \\
\text { Water 20- } \\
22\end{array}$ & $24-35$ & [196] \\
\hline Sewage sludge & $\begin{array}{c}\text { Mass: } 3.5 \mathrm{~kg}, \mathrm{~N}_{2}: 5-20 \\
\mathrm{~L} / \mathrm{min} \text {, power: } 6.4-8.0 \mathrm{~kW} \text { at } \\
2.45 \mathrm{GHz} \text {, time: } 120 \mathrm{~min}\end{array}$ & $350-500$ & & $\begin{array}{l}30.4 \% \text { of } \\
\text { organic } \\
\text { fraction }\end{array}$ & & [197] \\
\hline $\begin{array}{c}\text { Rice straw } \\
(0.425-0.850 \mathrm{~mm})\end{array}$ & $\begin{array}{c}3-5 \text { g sample, } \mathrm{N} 2 \text { flow: } 50 \\
\mathrm{~mL} / \mathrm{min}, 0.2-0.5 \mathrm{~kW}\end{array}$ & 400 & 28 & 23 & 49 & [198] \\
\hline $\begin{array}{c}\text { Oil palm shell (OPS) }< \\
0.850 \mathrm{~mm})\end{array}$ & $\begin{array}{c}\text { Mass: } 150 \mathrm{~g} \text {, ratio sample: } \\
\text { microwave absorber }(1: 0.25 \text {, } \\
1: 0.5 \text {, and } 1: 1) \text {, power } 0.45 \\
\mathrm{~kW} \text { at } 2.45 \mathrm{GHz} \text {, exposition } \\
\text { time: } 25 \text { min }\end{array}$ & $450-925$ & $40-65$ & $10-17$ & $25-47$ & [199] \\
\hline Corn stover & $\begin{array}{c}\text { Mass:50 g, power: } 0.3-0.9 \\
\mathrm{~kW} \text { at } 2.45 \mathrm{GHz}\end{array}$ & & & $\begin{array}{c}30(0.9 \\
\mathrm{kW})\end{array}$ & $\begin{array}{c}47(0.9 \\
\mathrm{kW})\end{array}$ & [200] \\
\hline $\begin{array}{c}\text { Rice husk }(\mathrm{RH})(0.149- \\
0.297 \mathrm{~mm}, 0.149-0.074 \\
\mathrm{~mm} \text { and }<0.074 \mathrm{~mm}) \\
\text { Sugar cane residues } \\
(\mathrm{SCR})\end{array}$ & $\begin{array}{l}\text { Mass: } 7-10 \mathrm{~g}, 0.15-0.4 \mathrm{~kW} \\
\text { at } 2.45 \mathrm{GHz} \text {, exposition } \\
\text { time: } 4-30 \mathrm{~min}\end{array}$ & $280-600$ & $\begin{array}{l}\text { RH: } \\
33-50 \\
\text { SCR:s } \\
25-67\end{array}$ & & & [201] \\
\hline
\end{tabular}


The main advantages of microwave pyrolysis compared to conventional technologies are: (1) it provides rapid heating ${ }^{185}$ (2) it is much cleaner and easier to control ${ }^{195}$ (3) it can be easily modularized for small applications (these processes can be developed for on-site processing reducing transportation cost) (4) heat is generated within the material (the particles are heated from the center), allowing the surface of the reactor to operate at lower temperatures, (5) high conversion efficiencies of energy to heat (80-85\%) are obtained and (6) higher power densities are used $^{185}$.

The main challenges and barrier for microwave pyrolysis are: (1) limited information is available on waste materials microwave relevant properties ${ }^{185}$ (2) uneven heating can lead to poor product quality control, (3) electricity is expensive and often produced from fossil fuels by Rankine cycles (with efficiency typically between 20 and $30 \%$ ), (4) electrical hazard that should be contained with an appropriate Faraday cage, (5) the presence of metals generate arcing that may damage the equipment, (6) the microwave heating systems are more expensive than traditional heating systems ${ }^{185}$. Some of the institutions with active programs in microwave pyrolysis are: The Chinese Academic of Sciences, the National Institute of Advanced Industrial Science and Technology of Japan, the Shandong University of China, the Technical Univesity of Vienna (Austria), the University of Malaysia Sarawak (Malaysia), the University of Minnesota (USA), Washington State University (Tri-cities), the University of Mississippi (USA), the University of Nothingham (UK), the University of York (UK) and the Ecole Politechnique de Montreal (Canada) ${ }^{16,42}$.

\section{Design and scale up of Pyrolysis units}

Business models: There are very few reports with information on the development of business models, technical design and techno-economic evaluation of pyrolysis units ${ }^{47,202,203}$. The technical design of the pyrolysis unit will depend on the business model selected ${ }^{203}$. The International Biochar Initiative (http://www.biochar-international.org/commercialization) has identified a number of business models for bio-char production including the characteristics of the feedstock, sustainability issues, associated production technology, potential co-products, 40 
economic and social challenges. The main business models discussed by the IBI and the technologies associated were: (1) Restoration site (e.g. forest, wetland) (mobile pyrolysis, charring piles in situ), (2) Managed forest (mobile pyrolysis, hog fuel for co-generation, feedstock for pellets and briquettes), (3) Forest product processing waste (Co-gen pyrolysis or gasification, feedstock for pellet or briquettes), (4) Biomass plantation (Co-gen pyrolysis or gasification, feedstock for pellets or briquettes), (5) Urban forestry and landscaping (Biochar, process heat, electricity, home heat), (6) Agricultural Waste-Industrial (Mobile pyrolysis, co-gen, pyrolysis or gasification), (7) Agricultural waste subsistence (Stoves, kilns feedstock for briquettes), (8) Municipal Solid Waste (MSW) (Co-gen pyrolysis or gasification) ${ }^{203}$.

Reactor Sizing: Although companies designing and building pyrolysis reactors may have developed scale up criteria and methodologies for sizing these equipment, the authors were not able to find systematic methodologies for the design of pyrolysis reactors in the open literature. Therefore, the design of pyrolysis reactors is still an art. For this reason, in this section we will briefly present a strategy based on our own experience. The design of pyrolysis reactors can be conducted following these steps: (1) Select throughput capacity, (2) Determine the biomass particle size to be used, (3) In the case of fluidized bed reactors select the appropriate sand/biomass particles size ratio, (4) Select the carrier gas to be used and quantify the carrier gas to be used (for fluidized bed reactors it is recommended $2.75 \mathrm{~kg}$ carrier gas $/ \mathrm{kg}$ dry biomass ${ }^{204}$ ); (5) Specify reaction temperature (in the case of fast pyrolysis typically $500{ }^{\circ} \mathrm{C}$ ) and conduct pyrolysis tests at lab or pilot facilities (6) Conduct a mass balance with the yield of products obtained experimentally (see information in tables 5, 6, 7, 8, 10); (7) Conduct energy balances to calculate how much heat has to be removed or supplied to the reactor. Thermodynamic information for the overall energy balance of pyrolysis reactors can be found elsewhere ${ }^{205-208}$. (8) Calculate the residence time of the biomass particle to achieve a targeted conversion. Information on experimental and modeling strategies (single particle models) to calculate conversion as a function of residence time can be found elsewhere ${ }^{72,75,209-211}$. (9) Calculate the solid hold up in the reactor. The residence time of the solid in the reactor depend on the hydrodynamic and the mechanic design of these reactors. In the case of rotary drums, it depends on the slope of the reactor, kiln rotational speed and the length and diameter of the reactor ${ }^{212}$. For 
fluidized beds, the retention of the solid is controlled by the terminal velocity of the converted biomass particle in the free board, (10) In the case of fluidized bed calculate or determine experimentally the minimum fluidization velocity (typically use 2 to 3 times the minimum fluidization velocity) $^{213,214}$, (11) Calculate the cross sectional area and diameter of the reactor ${ }^{213}$, (12) In the case of fluidized bed reactors calculate volume of expanded fluidized bed (sand and char particles) ${ }^{213}, 215$, (13) If designing fluidized bed reactors calculate the length and the diameter of the free board ${ }^{213}$, (14) Select the heating or cooling method to be used (e.g. indirect, direct or microwave heating) and calculate the heat transfer area needed to supply or remove the heat calculated in the energy balances ${ }^{213},(15)$ In the case of the fluidized bed reactors size the distribution grate $^{213}$.

\section{Challenges for the implementation of pyrolysis}

The development of pyrolysis technologies must overcome two major hurdles. The first one is associated with the lack of markets for pyrolysis oils and the second one with the lack of biochar derived products with well-defined performance characteristics. Consequently, it is imperative to accelerate the development and deployment of bio-oil refineries and the development and commercialization of engineered bio-char for environmental services. Developing flexible designs for pyrolysis units to produce high yields of both bio-oil and char is a technological challenge facing the thermochemical community.

The selection of pyrolysis technologies, their operational conditions, and the feedstocks to be used will depend mostly on economic tradeoffs ${ }^{216}$. The results presented in this review clearly show that there are multiple operational conditions and designs to obtain a wide range of products yields. Most of fast pyrolysis reactors reviewed are operated at conditions $\left(500{ }^{\circ} \mathrm{C}\right.$, small particles (below than $2 \mathrm{~mm}$ ), use of heat carrier (sand) and residence time of vapors below $2 \mathrm{~s}$ (use of a carrier gas)) for maximizing bio-oil yields with little regard for the quality of the product. The use of high volumes of carrier gas and the heat carrier reduce the energy efficiency of these processes, create important sand attrition problems, and makes it very difficult to condense the diluted vapors, requiring very large surface areas and considerable cooling power. 
Most of fast pyrolysis designs combust the char to satisfy the energy needs of the process. The difficulties to refine fast pyrolysis oils with high oxygen content is the main reason for the growing interest in catalytic pyrolysis for the production of bio-oils with lower oxygen content. The catalytic cracking strategies to reduce bio-oil oxygen content typically result in an increase in gas yield and coke formation. The converters reviewed are flexible enough to operate in conditions where bio-oil and biochar production is possible. More studies are needed to explore designs that take advantage of homogeneous secondary reactions in gas phase for oxygen removal from pyrolysis oils.

There is a vast diversity of situations in which pyrolysis can be applied (different feedstocks, scale, capacity, use of mobile or stationary units) as well as the diversity of products that can be obtained. This makes it very difficult to find an exclusive design that is sustainable across all the potential applications. Table 15 is an attempt to summarize the type of reactor suitable for a specific cases. A balanced investment in the creation of new knowledge (i.e., Science), in the design, testing and scale up of new technologies (for pyrolysis reactors and for rural bio-oil refineries) (i.e., Technology) and in the development of new products (from bio-oil and char) (i.e., Market) to build a shared vision that take advantage of existing infrastructure and is achievable in small steps are all critical for the deployment of a viable biomass based economy on pyrolysis technologies. 
Table 15. Summary of the technology status of pyrolysis reactors

\begin{tabular}{|c|c|c|c|c|}
\hline Type of reactor & Companies/Institutions ${ }^{\mathrm{a}}$ & $\begin{array}{l}\text { Technology } \\
\text { status }\end{array}$ & Remarks & References \\
\hline \multicolumn{5}{|c|}{ Kilns using Trunks of cordwood of Logs } \\
\hline $\begin{array}{l}\text { Earth kiln, traditional } \\
\text { methods }\end{array}$ & $\begin{array}{l}\text { Families for household } \\
\text { income, farmers, } \\
\text { communities }\end{array}$ & Commercial & $\begin{array}{l}\text { Widely used in } \\
\text { developing } \\
\text { nations }\end{array}$ & {$[115,217]$} \\
\hline $\begin{array}{c}\text { Cinder block, brick and } \\
\text { metal kilns (Brazilian and } \\
\text { Brazilian beehive and Half } \\
\text { orange, TPI kiln, New } \\
\text { Hampshire, Connecticut, } \\
\text { Missouri kiln) } \\
\end{array}$ & $\begin{array}{l}\text { Families for household } \\
\text { income, farmers, } \\
\text { communities, multiple } \\
\text { small companies - }\end{array}$ & Commercial & $\begin{array}{l}\text { Widely used in } \\
\text { developing } \\
\text { nations }\end{array}$ & {$[87,115]$} \\
\hline \multicolumn{5}{|c|}{ Retorts using trunks of cordwood or Logs } \\
\hline $\begin{array}{l}\text { Small metal kilns and } \\
\text { retorts }\end{array}$ & $\begin{array}{c}\text { Applied Gaia Corporation } \\
\text { (US) } \\
\text { Carbon Compost Co. Ltd } \\
\text { (UK) } \\
\text { Pressvess (UK) } \\
\text { CarbonZero, } \\
\text { (Switzerland) } \\
\text { Ithaka Institut } \\
\text { (Switzerland) } \\
\end{array}$ & Commercial & $\begin{array}{l}\text { Multiple designs, } \\
\text { Some can include } \\
\text { liquid recovery }\end{array}$ & $\begin{array}{l}\text { http://appliedgaia.com } \\
\underline{\text { http://www.carboncompos }} \\
\text { t.co.uk } \\
\underline{\text { http://www.pressvess.co.u }} \\
\underline{\mathrm{k}} \\
\mathrm{http://www.carbonzero.ch} \\
\text { http://www.ithaka- } \\
\underline{\text { institut.org/en/kon-tiki }}\end{array}$ \\
\hline Adam retort & $\begin{array}{l}\text { Adam + Partner } \\
\text { (Ethiopia) }\end{array}$ & Commercial & & {$[108,109]$} \\
\hline Wagon retorts & $\begin{array}{l}\text { O.E.T. Calusco (Imperiati } \\
\text { Trattamento Biomass) } \\
\text { Alterna Biocarbon }\end{array}$ & Commercial & $\begin{array}{l}\text { No operating } \\
\text { units }^{\mathrm{b}}\end{array}$ & {$[4,5,43,115]$} \\
\hline Reichert converter & $\begin{array}{l}\text { Evonik (Germany, } \\
\text { formerly Degussa) }\end{array}$ & Commercial & & {$[5,218]$} \\
\hline $\begin{array}{l}\text { French SIFIC Process } \\
\text { (CISR Lambiotte retort) }\end{array}$ & $\begin{array}{l}\text { Lambiotte (France) } \\
\text { Balt Carbon (Latvia) }\end{array}$ & Commercial & & $\frac{\text { http://www.lambiotte.com }}{[43,115]}$ \\
\hline $\begin{array}{l}\text { Lurgi carbonization retort } \\
\text { (Lurgi Umwelt GmbH) }\end{array}$ & $\begin{array}{c}\text { Simcoa (Australia) } \\
\text { Lurgi LR (Germany) }\end{array}$ & Commercial & & $\frac{\text { http://www.simcoa.com.au }}{{ }_{2}[43,16]}$ \\
\hline Twin type retorts & $\begin{array}{l}\text { Charbon Engineering } \\
\text { (Carbon-Twin) } \\
\text { (Netherlands) } \\
\text { Clean Fuels } \\
\text { (Netherlands) } \\
\text { VMR Systems } \\
\text { (Netherlands) } \\
\text { CG2000 Carboniser } \\
\text { Ibero Massa Florestal } \\
\text { (Portugal) } \\
\end{array}$ & Commercial & $\begin{array}{l}\text { Some designs can } \\
\text { include liquid } \\
\text { recovery }\end{array}$ & 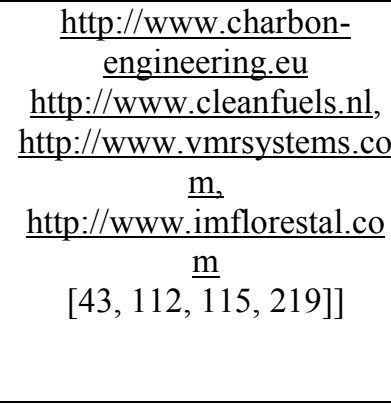 \\
\hline Flash Carbonization & University of Hawai'i & Pilot Plant & & {$[6,43]$} \\
\hline
\end{tabular}


Table 15. Summary of the technology status (Continuation....)

\begin{tabular}{|c|c|c|c|c|}
\hline Type of reactor & Companies/Institutions ${ }^{\mathrm{a}}$ & $\begin{array}{l}\text { Technology } \\
\text { status }\end{array}$ & Remarks & References \\
\hline \multicolumn{5}{|c|}{ Converters using chips and pellets } \\
\hline $\begin{array}{l}\text { Herreshoff multiple hearth } \\
\text { furnaces }\end{array}$ & $\begin{array}{l}\text { (BigChar) Pyrocal Pty } \\
\text { Ltd (Australia) } \\
\text { CSE Hankin } \\
\text { Environmental System } \\
\text { (USA) } \\
\end{array}$ & Commercial & & $\begin{array}{c}\frac{\text { http://www.bigchar.com.au }}{\text { http://hankines.com }} \\
{[115,119]}\end{array}$ \\
\hline $\begin{array}{l}\text { Autogenous pyrolysis } \\
\text { reactor }\end{array}$ & CSIRO (Australia) & Pilot Plant & & [220] \\
\hline \multirow[t]{3}{*}{ Auger reactors } & $\begin{array}{c}\text { BioGreen Spirajoule } \\
\text { (France) } \\
\text { Genesis Industries (USA) } \\
\text { BioMaCon GmbH } \\
\text { (Germany) } \\
\text { Karr Group (USA) } \\
\text { Polvax (Ukraine) } \\
\text { Pro-Natura (France) }\end{array}$ & Commercial & $\begin{array}{l}\text { Multiple designs } \\
\text { and companies } \\
\text { offering auger } \\
\text { reactors }\end{array}$ & $\begin{array}{c}\frac{\mathrm{http}: / / \text { www.biogreen- }}{\text { energy.com, }} \\
\underline{\mathrm{http}: / / \text { egenindustries.com }} \\
\underline{\mathrm{http}: / / \text { www.biomacon.com }} \\
\underline{\mathrm{http}: / / \text { karrgroupco.com }} \\
\underline{\mathrm{http}: / / \text { www.pyrolys.net }} \\
\text { http://www.pronatura.org/?p } \\
\text { age id=521\&lang=en, [115] }\end{array}$ \\
\hline & $\begin{array}{c}\text { Bioliq, Karlsruher } \\
\text { Institute für Technologie } \\
\text { (Germany), } \\
\text { Energy Farmers } \\
\text { (Australia) } \\
\text { ABRITech (Canada) } \\
\text { Renewable Oil } \\
\text { International LLC (USA) }\end{array}$ & $\begin{array}{l}\text { Demonstrati } \\
\text { on }\end{array}$ & & $\begin{array}{l}\frac{\underline{\mathrm{http}: / / \text { www.energyfarmers.co }}}{\mathrm{m} \cdot \mathrm{au}} \\
\frac{\mathrm{http}: / / \text { www.abritechinc.com }}{\mathrm{http} / / \text { demoplants21.bioenerg }} \\
\frac{\mathrm{y} 2020 . \mathrm{eu} / \mathrm{projects} / \text { displayma }}{\mathrm{p} / \mathrm{twhWVt}} \\
\frac{\text { www.renewableoil.com }}{[221,16]}\end{array}$ \\
\hline & $\begin{array}{c}\text { Thermo-catalytic } \\
\text { reforming (Fraunhofer } \\
\text { UMSICHT \& Susteen } \\
\text { Technologies, Germany), } \\
\text { Alternative Energy } \\
\text { Solutions Ltd (New } \\
\text { Zealand) } \\
\text { Renewable Oil Int, } \\
\text { (USA) }\end{array}$ & Pilot Plant & & $\frac{\text { http://www.susteen-tech.com }}{[16,222]}$ \\
\hline \multirow[t]{2}{*}{$\begin{array}{l}\text { Indirectly heated Rotary } \\
\text { kilns }\end{array}$} & $\begin{array}{c}\text { Amaron Energy (USA) } \\
\text { Mitsubishi Heavy } \\
\text { Industries (Japan) } \\
\text { Ansac } \\
\text { Anergy Ltd } \\
\text { 3R Environmental } \\
\text { Technologies Group } \\
\text { Mitsui R21 } \\
\text { ITC }\end{array}$ & Commercial & $\begin{array}{l}\text { Multiple plants } \\
\text { for waste } \\
\text { treatment (MSW, } \\
\text { sludge) are } \\
\text { adaptable to } \\
\text { biomass } \\
\text { pyrolysis. }\end{array}$ & $\begin{array}{l}\frac{\text { http://www.amaronenergy.co }}{\underline{\mathrm{m}},} \\
\frac{\text { http://www.mhiec.co.jp/en/pr }}{\text { oducts/water/sludge/contents }} \\
\frac{\text { /sludge_carbonization_facilit }}{\frac{\text { y.html }}{[222]}}\end{array}$ \\
\hline & $\begin{array}{c}\text { University of Perugia } \\
\text { (Italy) }\end{array}$ & Pilot Plant & & [223] \\
\hline
\end{tabular}


Table 15. Summary of the technology status of pyrolysis reactors (Continuation....)

\begin{tabular}{|c|c|c|c|c|}
\hline Type of reactor & Companies/Institutions ${ }^{\mathrm{a}}$ & $\begin{array}{c}\text { Technology } \\
\text { status }\end{array}$ & Remarks & References \\
\hline \multicolumn{5}{|c|}{ Fast/intermediate Pyrolysis Reactors using chips } \\
\hline $\begin{array}{l}\text { Moving Agitated bed } \\
\text { (Pyrovac) }\end{array}$ & Pyrovac & $\begin{array}{l}\text { Demonstrati } \\
\text { on }\end{array}$ & & {$[134,135]$} \\
\hline Shelf reactors & & Commercial & $\begin{array}{c}\text { No operating } \\
\text { units }\end{array}$ & {$[4,46]$} \\
\hline Paddle pyrolysis kiln & BEST & $\begin{array}{l}\text { Demonstrati } \\
\text { on }\end{array}$ & - & BEST website not working \\
\hline $\begin{array}{l}\text { Ablative pyrolysis } \\
\text { Pytec, German }\end{array}$ & Pytec & $\begin{array}{l}\text { Demonstrati } \\
\text { on }\end{array}$ & $\begin{array}{c}\text { Web site is not } \\
\text { working- }\end{array}$ & [16] \\
\hline Rotating cone & BTG-BTL, Netherlands & Commercial & & $\begin{array}{l}\frac{\text { http://www.empyroproject. }}{{ }_{\text {eu, }}} \\
\underline{\text { http://www.btgworld.com/ }} \\
\underline{\text { en/[16] }}\end{array}$ \\
\hline \multicolumn{5}{|c|}{ Fast Pyrolysis using fine particles (catalytic and non-catalytic processes) } \\
\hline $\begin{array}{l}\text { Bubbling Fluidized bed } \\
\text { reactors. }\end{array}$ & $\begin{array}{c}\text { Anellotech (USA) } \\
\text { Valmet - Fortum } \\
\text { (Finland) } \\
\text { Agritherm (Canada) } \\
\text { RTI (USA) } \\
\text { Avello Bioenergy (USA) } \\
\text { Bioware, (Brasil) } \\
\text { Biomass Engineering Ltd } \\
\text { (BEL), UK } \\
\text { Nettenergy BV } \\
\text { (Netherlands) }\end{array}$ & $\begin{array}{l}\text { Commercial } \\
/ \\
\text { Demonstrati } \\
\text { on }\end{array}$ & Static/Mobile & $\begin{array}{c}\frac{\begin{array}{c}\text { http://anellotech.com } \\
\text { http://www.fortum.com }\end{array}}{\frac{\text { http://agri-therm.com }}{\text { www.rti.org/energy }}} \\
\frac{\text { http://www.avellobioenerg }}{\text { y.com }} \\
\frac{\text { https://www.bioware.com. }}{\text { br }} \\
\frac{\text { http://www.nettenergy.co }}{\frac{\text { m/index.php/en/ }}{[16,42]}}\end{array}$ \\
\hline Circulating bed reactors & $\begin{array}{l}\text { Rapid Thermal } \\
\text { Processing: Ensyn, } \\
\text { (USA), Envergent } \\
\text { Technologies (USA) } \\
\text { Metso (Finland) } \\
\text { Anaeris Technology } \\
\text { (former Kior) }\end{array}$ & $\begin{array}{l}\text { Commercial } \\
/ \\
\text { Demonstrati } \\
\text { on }\end{array}$ & & $\begin{array}{l}\frac{\underline{\text { http://www.ensyn.com }}}{\text { https://www.envergenttech }} \\
\frac{\underline{\text { com }}}{\text { http://www.inaeristech.co }} \\
\underline{\mathrm{m} /} / 16]\end{array}$ \\
\hline Spouted bed & Ikerlan (Spain) & Pilot Plant & & {$[16,178]$} \\
\hline \multicolumn{5}{|c|}{ Microwave pyrolysis } \\
\hline Microwave pyrolysis & $\begin{array}{c}\text { Carbonscape (New } \\
\text { Zealand) } \\
\text { Beijing Sino-Green } \\
\text { Technology Co., Ltd } \\
\text { (China) } \\
\text { Bioenergy 2020 + gmbh } \\
\text { (Austria) }\end{array}$ & Pilot Plant & & $\frac{\text { http://carbonscape.com, }}{[186,16]}$ \\
\hline
\end{tabular}




\section{Conclusions}

The number of publications on slow and fast pyrolysis reactors has been growing steadily in the last thirty years. The community interested in these reactors is formed by researchers interested on char production and those interested on bio-oil production. This paper reviews slow, intermediate, fast and microwave pyrolysis intending that companies and academic institutions, researching, designing and commercializing pyrolysis/carbonization reactors can take advantage of the technological solutions shown. Very little progress has been made in the last century in the design of kilns. The release of large quantities of pyrolysis vapors to the atmosphere and/or their condensation in soils are major sources of pollution that need to be urgently addressed. Several of the retorts used today were developed and commercialized by the "wood distillation industry". These units were designed for the carbonization of logs. However, deforestation issues and the limited availability of logs for carbonization are major hurdles for their widespread deployment in today's world. The converters are receiving growing attention for their capacity to convert forest and agricultural residues in the form of chips and shredded materials into bio-oil and charcoal. These systems do not require the use of large volumes of carrier gas or a heat carrier (sand). Nevertheless, the lack of commercial interest for fine chars produced by these systems has been a major hurdle for the commercialization of this technology. The growing interest on using char as soil amendments and the development of technologies for the production of char pellets and briquettes from these fines are catalyzing new companies commercializing these designs. The current design and operation of fast pyrolysis reactors is based on conditions maximizing bio-oil yields with little regard for the quality of the bio-oil produced. High bio-oil yield is achieved at $500{ }^{\circ} \mathrm{C}$, using small particles (less than $1 \mathrm{~mm}$ ) a heat carrier (sand) and using high volumes of carrier gas to reduce the residence time of vapors below $2 \mathrm{~s}$. The energy need of these reactors is typically satisfied by char combustion. Consequently, most of these processes do not commercialize char as one of their products. The lack of commercial bio-oil refineries is the main barrier for the commercialization of these reactors. Problems with fast pyrolysis oil refining are catalyzing interest on strategies to produce oils with lower oxygen content. Most of these strategies result in high gas yield, which is an opportunity to explore the use of the gases to satisfy part of the energy needed of the system, without scarifying 
char production. Microwave pyrolysis is a promising technology for the development of small convenient systems for waste management.

Acknowledgements: M.G-P acknowledges the Waste to Fuel program from the Washington State Department of Ecology, Washington State Agricultural Research Center (NIFA-HatchWNP00701) and the National Science Foundation (CBET-1434073, CAREER CBET-1150430) for their financial support.

\section{References:}

1. Withrow J: The Chemical Engineering of the Hardwood Distillation Industry. Ind. Eng. Chem. Res. (1915), Vol. 7, No II, p. 912

2. Brown N.C: The hardwood distillation industry in New York. The New York State College of Forestry at Syracuse University. January 1917.

3. Bunbury, H. M., The destructive distillation of wood, Benn Brothers, Ltd., London, 1923.

4. Klar M, Rule A: The Technology of Wood Distillation. London Chapman \& Hall LTD, 1925.

5. Emrich W., Handbook of charcoal Making. The Traditional and Industrial Methods, D. Reidel Publishing Company, 1985

6. Antal, MJ, Grønli M., The Art, Science, and Technology of Charcoal Production, Ind. Eng. Chem. Res. 2003, 42, 1619-1640.

7. Antal MJ, Mochidzuki K, Paredes LS: Flash Carbonization of Biomass. Ind. Eng. Chem. Res., 2003, 42 (16), 3690-3699.

8. Veitch, F.P., Chemical Methods for Utilizing Wood. Including destructive distillation, recovery of Turpentin, rosin and pulp, and the preparation of alcohols and oxalic acid. USDA, 1907

9. Canham, H. O., The wood chemical industry in the Northeast: An old industry with new possibilities, Northern Woodlands, February 8th 2010, http:/www.faqs.org/photodict/phrase/10393/kilns.html

10. Massengale R, Black gold:A history of charcoal in Missouri, Author House, Bloomington, 2006 
11. Scott DS, Piskorz J, The Continuous Flash Pyrolysis of Biomass. Can. J. Chem. Eng. 1984, $62(3), 404-412$.

12. Scot DS, Piskorz J, Radlein D. Liquid products from the continuous flash pyrolysis of biomass. Ind. Eng Chem Process Des Dev., 1985, 24, 581-888.

13. Bridgwater AV, Czernik S, Piskorz J: The status of biomass fast pyrolysis. In: Bridgwater AV, editor. Fast pyrolysis of biomass a handbook, Vol. 2. Newbury, UK, CPL Press, 2002, p. 1-22.

14.Bridgwater AV, Peacocke GVC, Fast Pyrolysis Processes for Biomass. Renewable and Sustainable Energy Reviews, 2000, 4, 1-73

15. Czernik S, Bridgwater A.V., Overview of Applications of Biomass Fast Pyrolysis Oil. Energy \& Fuel, 2004, 18, 2, 977-997

16. Bridgwater AV, Review of fast pyrolysis of biomass and product upgrading. Biomass and Bioenergy, 38, 2012, 68-94

17. Diebold J.P., Bridgwater A.V., Overview of Fast Pyrolysis of Biomass for the Production of Liquid Fuels. Fast Pyrolysis of Biomass. A Handbook, Eds. Bridgwater A et al. CPL press, 1999, 14-32.

18. Kersten SRA, Wang X, Prins W, van Swaaij WPM: Biomass pyrolysis in a fluidized bed reactor. Part 1: literature review and model simulations. Ind Eng Chem Res., 2005, 44: 8773-85.

19. Mohan D, Pittman CU, Steele PH: Pyrolysis of Wood/Biomass: A critical review. Energy \&Fuels, 2006, 20 (3), 848-889.

20. Elliott DC: Historical developments in hydroprocessing bio-oils. Energy\&Fuels, 2007, 21: 1792-1815

21. Elliott D: Advancement of Bio-oil Utilization for Refinery Feedstock. Presented at the Washington Bioenergy Research Symposium. November 8, 2010, Seattle, Washington State (http://www.pacificbiomass.org/documents/Elliott\%20(C1).pdf).

22. Kumar S, Lange J-P, Van Rossum G, Kersten SRA: Bio-oil fractionation by temperatureswing extraction: Principle and Application. Biomass and Bioenergy, 2015, 83, 96-104 
23. Ijmker HM, Gramblicka M, Kersten SRA, van der Ham AGJ, Schuur B: Acetic Acid extraction from aqueous solutions using fatty acids. Separation and Purification technology $125,2014,256-263$.

24. Li X, Luque-Moreno LC, Oudenhoven SRC, Rehmann L, Kersten SRA, Schuur B: Aromatics extraction from pyrolytic sugars using ionic liquid to enhance sugar fermentability. Bioresource Technology, 2016, 216, 12-18.

25. Li X, Kersten SRA, Schuur B: Extraction of acetic acid, glycoaldehyde and acetol from aqueous solutions mimicking pyrolysis oil cuts using ionic liquid. Separation and Purification technology. 175, 2017, 24, 498-505

26. FAO 2017. The charcoal transition: greening the charcoal value chain to mitigate climate change and improve local livelihoods, by J. van Dam. Rome, Food and Agricultural Organization of the United Nations. http://www.fao.org/3/a-i6935e.pdf

27. Stassen HE: Chapter 14: Current Issues in Charcoal Production and Use. In: Biomass power for the world. Edited Wim PM van Swaaij, Kersten SRA, Palz W, 2015.

28. Mangue, P. D., Review of the existing studies related to fuelwood and/or charcoal in Mozambique, Project GCP/INT/679/EC, EC-FAO Partnership Programme, 2000

29. Kammen DM, Lew DJ: Review of Technologies for the Production and Use of Char. Energy and Resources Group \& Goldman School of Public Policy. UC Berkley and NREL, 2005

30. Seidel A, Charcoal in Africa. Importance, Problems and Possible Strategies. Eschborn, 2008.

31. FAO, Simple technologies for Charcoal Making, FAO Forestry paper 41, 1983. Available at: http://www.fao.org/docrep/X5328e/X5328e00.htm

32. FAO (2017), FAOSTAT, Forestry Production and Trade, Retrieved February $17^{\text {th }}, 2017$, from: http://www.fao.org/faostat/en/\#data/FO

33. Chidumayo EN, Gumbo DJ: The environmental impacts of charcoal production in tropical ecosystems of the world: A synthesis, 2013, 17, 2, 86-94

34. Bailis R, Rujanavech C, Dwivedi P, de Oliveire Vilela A, Chang H, Carneiro de Miranda R: Innovation in charcoal production: A comparative life-cycle assessment of two kiln technologies in Brazil. Energy for Sustainable Development, 2013, 17, 2, 189-200 
35. Kituyi E: Towards sustainable production and use of charcoal in Kenya: exploring the potential in life cycle management approach. Journal of Cleaner Production, 2004, 12, 1047-1057

36. Norgate T, Langberg D: Environmental and Economic Aspects of Charcoal Use in Steelmaking. ISIJ International, 2009, 49, 4, 587-595

37. Amonette J: Biochar and Bioenergy: What Can they Do to Help Mitigate Climate Change. Washington State Bioenergy Research Symposium, Seattle, WA, 8 November 2010. http://www.pacificbiomass.org/documents/Amonette\%20(C1).pdf

38. Lehmann, J., Stephen, J., Char for Environmental Management: An Introduction, In: Biochar for Environmental Management. Science and Technology, Earthscan Publishers Ltd, 2009

39. Woolf D, Amonette J, Stree-Perrot A, Lehmann J, Joseph S: Sustainable biochar to mitigate global change. Nature Communications, August 2010 OPEN ACCESS online at: www.nature.com/naturecommunications

40. Ogawa, M., Okimori, Y., Pioneering works in biochar research, Japan, Australian Journal of Soil Research, 2010, 48, 489-500

41. Trossero M, Domac J, Siemons R: Industrial Char Production. TCP/CRO/3101 (A) Development of a sustainable char industry. FAO, June 2008, Zagreb, Croatia

42. Meier D, van de Beld B, Bridgwater AV, Elliott D, Oasmaa A, Preto F: State of the art of fast pyrolysis in IEA bioenergy member countries. Renewable and Sustainable Energy Reviews 20 (2013) 619-641

43. Grønli, 2010, M., Pyrolysis and Charcoal, http://www.bioforsk.no/ikbViewer/Content/71499/Biokarbonseminar\%20\%20\%C5s\%201103-2010\%20Morten\%20Gr\%F8nli.pdf; Retrieved February 26, 2017,

44. Motasemi F, Afzal MT: A review on the microwave-assisted pyrolysis technique. Renewable and Sustainable Energy Reviews.,2013, 28, 317-330

45. Mushtaq F, Mat R, Nasir-Ani F: A review on microwave assisted pyrolysis of coal and biomass for fuel production. Renewable and Sustainable Energy Reviews 39, 2014, 555574

46. Dumesny P, Noyer J Wood Products. Distillates and Extracts. Part I. The Chemical Products of Wood distillation. Part II. Dyeing and tanning extracts from wood. London, Scott, 51 
Greenwood \& Son. "The oil and colour Trates Journal "Offices \& Broadway, Ludgate Hill, E.C.1908.

47. Lynch J, Joseph S: Guidelines for the Development and Testing of Pyrolysis Plants to Produce Char. International Biochar Initiative, IBI 2010. http://www.biocharinternational.org/sites/default/files/IBI_Pyrolysis_Plant_Guidelines.pdf Retrieved February 26,2017 ,

48. Wang X, Kersten SRA, Prins W, van Swaaij WPM: Biomass Pyrolysis in a Fluidized bed reactor. Part 2: Experimental Validation of Model results. Ind. Eng. Chem. Res. 2005, 44, 8786-8795

49. Shen J, Wang X-S, Garcia-Perez M, Mourant D, Rhodes MJ, Li C-Z: Effects of particle size on the fast pyrolysis of oil mallee woody biomass. Fuel, 2009, 88, 1810-1817

50. Westerhof RJM, Nygard HS, van Swaaij WPM, Kersten SRA, Brilman DWF. Effect of Particle Geometry and Microstructure on Fast Pyrolysis of Beech Wood. Energy \& Fuels, 2012; 26, 4, 2274

51. Zhou S, Garcia-Perez M, Pecha B, McDonald AG, Westerhof RJM: Effect of particle size on the composition of lignin derived oligomers obtained by the fast pyrolysis of beech wood. Fuel, 2014, 125, 15-19

52. Patwardhan PR, Satrio J, Brown RC, Shanks BH: Influence of inorganoic salts on the primary pyrolysis products of cellulose. Bioresource Technology, 2010, 101, 4646-4655

53. Mourant D, Wang Z, He M, Wang XS, Garcia-Perez M, Ling K, :Li C-Z: Mallee wood fast pyrolysis: Effects of alkali and alkaline earth metallic species on the yield and composition of bio-oil. Fuel, 2011, 90, 2915-2922

54. Oasmaa A, Sundqvist T, Kuoppala E, Garcia-Perez M, Solantausta Y, Lindfors C: Controlling Phase Stability of Biomass Fast Pyrolysis Bio-oils. Energy\&Fuels, 2015, 29, 7, 4373-4381

55. Hoekstra E, Westerhof RJM, Brikman W, Van Swaaij WPM, Kersten SRA, Hogendoorn KJA: Heterogeneous and Homogeneous Reactions of Pyrolysis Vapors from Pine Wood. AiChE Journal, 2012, 58, 9, 2830-2842 
56. Hoekstra E, Van Swaaij WPM, Kersten SRA, Hogendoorn KJA: Fast Pyrolysis in a novel wire-mesh reactor: Decomposition of pine wood and model compounds. Chemical Engineering Journal, 2012, 187, 172-184

57. Zhou S, Garcia-Perez M, Pecha B, McDonald A, Kersten SRA, Westerhof RJM: Secondary Vapor Phase Reactions of Lignin-Derived Oligomers Obtained by Fast Pyrolysis of Pine Wood. Energy\&Fuels, 2013, 27, 3, 1428-1438

58. Mok S. W., Antal, M. J., Szabo, P., Varhegyi, G., Zelei, B., Formation of Charcoal from Biomass in a Sealed Reactor, Ind. Eng. Chem. Res. 1992, 31, 1162-1166.

59. Garcia-Perez M, Chaala A, Roy C: Vacuum pyrolysis of sugarcane bagasse. J. Anal. Appl. Pyrolysis, 2002, 65, 111-136

60. Garcia-Perez M, Chaala A, Pakdel H, Kretchmer D, Roy C: Vacuum pyrolysis of softwood and hardwood biomass. Comparison between product yields and bio-oil properties. J. Anal. Appl. Pyrolysis, 2007, 78, 104-116

61. Liaw S-S, Zhou S, Wu H, Garcia-Perez: Effect of Pretreatment Temperature on the Yield and Properties of Bio-Oils obtained from the Auger Pyrolysis of Douglas Fir Wood. Fuel, 2013, $103,672-682$

62. Westerhof RJM, Brilman DWF, Garcia-Perez M, Wang Z, Oudenhoven SRG, Kersten SRA. Stepwise fast pyrolysis of pine wood. Energy\&Fuels, 2012; 26, 12, 7263.

63. Montoya J, Pecha B, Roman D, Chejna-Janna F, Garcia-Perez M: Effect of temperature and heating rate on product distribution from the pyrolysis of sugarcane bagasse in a hot plate reactor. J. Anal. Appl. Pyrolysis 123, 2017, 347-362

64. Wooten J.B., Seeman J.I., Hajaligol M.R. 2004. Observation and Characterization of Cellulose Pyrolysis Intermediates by C CPMAS NMR. A New Mechanistic Model ${ }^{13}$ Energy \& Fuels, 2003, 18, 1.

65. Westerhof RJM, Oudenhoven SRG, Marathe PS, Englen M, Garcia-Perez M, Wang Z, Kersten SRA: The Interplay between Chemistry and Heat/Mass Transfer during Fast Pyrolysis of Cellulose. Reaction Chemistry \& Engineering, 2016, 1, 555.

66. Dauenhauer PJ, Colby JL, Balonek CM, Suszynski WJ, Schmidt LD: Reactive boiling of cellulose for integrated catalysis through an intermediate liquid. Green Chem. 2009, 11, $1555-1561$ 
67. Montoya J, Pecha B, Chejne-Janna F, Garcia-Perez M: Micro-explosion of liquid intermediates during the fast pyrolysis of sucrose and organosolv lignin. J. Anal. Appl. Pyrolysis, 2016, 122, 106-121

68. Pelaez-Samaniego MR, Yadama V, Garcia-Perez M, Lowell E, McDonald AG: Effect of temperature during wood torrefaction on the formation of lignin liquid intermediates. $J$. Anal. Appl. Pyrolysis. 2014, 109, 222-233

69. Mamleev V, Bourgigot S, Le Bras M, Yvon J: The facts and hypotheses relating to the phenomenological model of cellulose pyrolysis: Interdependence of the steps. J. Anal. Appl. Pyrolysis, 2009, 84, 1-17.

70. Graham RG, Bergougnou MA, Overend RP: Fast Pyrolysis of Biomass. J. of Anal. Appl. Pyrolysis, 6, 1984, 95-135.

71. Graham R.G., Bergougnou M.A., Freel B.A. The kinetics of vapor phase cellulose fast pyrolysis reactions. Biomass and Bioenergy, 1994, 7, 1-6, 33-47

72. Pyle DL, Zaror CA: Heat transfer and kinetics in the low temperature pyrolysis of solids. Chemical Engineering Science, 1984, 36, 1, 147-158,

73. Di Blasi C, Galgano A, Branca C: Effects of Potassium Hydroxide Impregnation on Wood Pyrolysis. Energy \& Fuels, 2009, 23, 1045-1054

74. Garcia-Perez, M., Xiao Shan Wang, Jun Shen, Martin J. Rhodes, Fujun Tian,Woo-Jin Lee, Hongwei Wu, and Chun-Zhu Li, Fast Pyrolysis of Oil Mallee Woody Biomass: Effect of Temperature on the Yield and Quality of Pyrolysis Products, Ind. Eng. Chem. Res. 2008, 47, 1846-1854

75. Kersten SRA, Garcia-Perez M: Recent developments in fast pyrolysis of lingo-cellulosic materials. Current Opinion in Biotechnology, 2013, 24: 414-420

76. Coates R, Gardner T: Mobile Pyrolysis Process for Conversion of Biomass into Energy Products. Amaron Energy. Presentation at the 2014 Washington Demonstration. http://www.pacificbiomass.org/documents/Amaron.pdf, Accessed on Feb 26, 2017

77. Liaw S-S, Wang Z, Ndegwa P, Frear C, Ha S, Li C-Z, et al. Effect of pyrolysis temperature on the yield and properties of bio-oils obtained from the auger pyrolysis of Douglas Fir wood. J. Anal. Appl. Pyrolysis, 2012;93, 52. 
78. Rousset P: From biomass to fuel, power and chemicals. Brazilian charcoal-based pig iron. Cirad. Presentation at the Department of Aeronautics and Astronautics, National Cheng Kung University, Taiwan, ROC, November, $6^{\text {th }}, \quad 2014$ http://agritrop.cirad.fr/578836/1/taiwan\%20nov\%202014\%20ver2\%20OK.pdf Accessed on Feb. 26, 2017

79. Boateng AA, Garcia-Perez M, Masek O, Brown R, del Campo B: Chapter 4: Biochar production technology. In: Biochar for Environmental Management. Science, Technology, and implementation. Edited by Johannes Lehmann and Stephen Joseph. Second Edition 2015,63

80. International Biochar Inititative. Standardized Product Definition and Product Testing Guidelines for Biochar That Is Used in Soil. 2015 http://www.biocharinternational.org/characterizationstandard

81. Oasmaa A, Fonts I, Pelaez-Samaniego MR, Garcia-Perez ME, Garcia-Perez M: Pyrolysis Oil Multiphase behavior and Phase Stability: A Review. Energy \& Fuels 2016, 30, 6179-6200

82. Garcia-Perez M, Chaala A, Pakdel H, Kretschmer D, Roy C: Characterization of bio-oils in Chemical families. Biomass and Bioenergy 2007, 31, 222-242

83. Stankovikj F, Garcia-Perez M: TG-FTIR Method for the Characterization of Bio-oils in Chemical Families. Energy and Fuels, 2017, 31, 1689-1701.

84. Stankovikj F, McDonald A, Helms GL, Olarte MV, Garcia-Perez M: Characterization of the Water Soluble Fraction of Biomass Pyrolysis Oils. Energy Fuels, 31, 2017, 1650-1664

85. Stankovikj F, McDonald A, Helms GL, Garcia-Perez M: Quantification of Bio-oil Functional Groups and Evidence of the Presence of Pyrolytic Humins Energy \& Fuels, 2016, 30, 65056524

86. Garcia-Perez M, Chaala A, Pakdel H, Kretschmer D, Rodrigue D, Roy C: Multiphase Structure of Bio-oils. Energy \& Fuels, 2006, 20 (1), 364-375

87. Riuji Lohri C, Mtoro Rajabu H, Sweeney DJ, Zurbrugg C: Char fuel production in developing countries- A review of urban biowaste carbonization. Renewable and Sustainable Energy Reviews, 2016, 59, 1514-1530

88. FAO, Simple technologies for charcoal making, FAO Forestry paper 41, 1987. Retrieved November $20^{\text {th }}, 2010$, from: http://www.fao.org/docrep/x5328e/x5328e00.htm\#Contents 
89. Seboka Y: Chapter 6. Chacoal Production: Opportunities and barriers for improving efficiency and sustainability. In: Bio-carbon opportunities in eastern \& southern Africa. Harnessing Carbon, Finance to Promote Sustainable Forestry, agro-forestry and Bio-energy. UNDP 2009. $\quad$ http://www.environmentportal.in/files/Biocarbon\%20in\%20Africa.pdf\#page=113

90. Schenkel, Y., Bertaux, P., Vanwijnbserghe, S., Carre, J., An evaluation of the mound kiln carbonization technique, Biomass and Bioenergy, 1998, 14, 5/6, 505-516.

91. Nahayo A, Ekise I, Mukarugwiza A: Comparative Study on Charcoal Yield Produced by Traditional and Improved kilns: A study of Nyaruguru and Nyamagabe Distrists in Southern Province of Rwanda. Energy and Environment Research, 2013, 3, 1.

92. Menemencioglu K: Traditional wood charcoal production labor in Turkish forestry (Cankiri sample). Journal of Food, Agriculture \& Environment, 2013, 11, 2, 1136-1142

93. De Oliveira Vilela A, Silva Lora E, Roman-Quintero Q, Antonio-Vicintin R, da Silva e Souzo TP: A new Technology for the combined production of charcoal and electricity through cogeneration. Biomass and Bioenergy, 2014, 69, 222-240

94. Toole AW, Lane PH, Arbogast C, Smith WR, Peter R, Locke E, Beglinger E, Erickson E.C.O.: Char Production, Marketing and Use. Forest Products Laboratory, Madison Wisconsin. USDA-Forest Service, University of Wisconsin. Report 1961, July 1961.

95. Pelaez-Samaniego M.R., Garcia-Perez M, Cortez LB, Rosillo-Calle F, Mesa J: Improvements of Brazilian carbonization industry as part of the creation of a global biomass economy. Renewable and Sustainable Energy Reviews, 2008, 12 1063-1086.

96. Brito, J. O., Princípios de produção e utilização de carvão vegetal de madeira, Documentos florestais, Piracicaba (9): 1 -19, mai. 1990

97. Bustamante-Garcia V, Carrillo-Parra A, Gonzalez-Rodriguez H, Ramirez-Lozano RG, Corral-Rivas JJ, Garza-Ocanas F: Evaluation of a charcoal production process from forest residues of Quercus sideroxyla hum, \& Bpnpl. In a Brazilian beehive kiln. Industrial Crops and products, 2013, 42, 169-174.

98. Yronwode, P., From the hills to the grills, Missouri Resources Magazine, Spring 2000

99. Lemieux, P. M., Emissions of Air Toxics from a Simulated Charcoal Kiln Equipped with an Afterburner (Project Summary), EPA, March 2001 
100. Braun S., Missouri Charcoal-Makers Agree to Clean Their Kilns, August 14 1997, Los Angeles Times, Retrieved January $27^{\text {th }}, \quad 2011$, from: http://articles.latimes.com/1997/aug/14/news/mn-22314

101. Campbell R.R., A revolution in the heartland: Changes in rural culture, family and communities 1900-2000, Columbia (MO), 2004, Retrieved January 27, 2011, from: http://web.missouri.edu/ campbellr/Book/Chapter28.htm\#E11

102. Fink, R. J., Fink, R. L., An assessment of biomass feedstock availability in Missouri, Final Report, Contract No. SEBSRP-SSEB-2004XX-KLP-001, April, 2005

103. Sparrevik M, Adam C, Martinsen V, Jubaedah, Cornelissen G: Emissions of gases and particles from charcoal/biochar production in rural areas using medium-sized traditional and improved "retort" kilns. Biomass and Bioenergy, 2015, 72, 65-73

104. Baldwin, H I., The New Hampshire charcoal kiln, Concord, New Hampshire, 1958.

105. VT, 2010, Design and instructions for making a New Hampshire-style metal charcoal kiln from readily-available materials, Adaptation of New Hampshire kilns, at: http://www.forestry.vt.edu/charcoal/documents/kiln-design.pdf

106. Skok, R.A., Beazley, R., Small kiln charcoal production possibilities in Minnessota, Minnesota Forestry Notes, April 15, 1955

107. Simmons, F. C., Charcoal from portable kilns and fixed installations, An international journal of forestry and forest industries, Vol. 17, 1963, Retrieved January 27th, 2011, from: http://www.fao.org/docrep/00950e/00950e07.htm\#TopOfPage

108. Adam+Partner, 2010, Accessed November 15 ${ }^{\text {th }}$, 2010, from: http://www.biocoal.org/index.html

109. Adam JC: Improved and more environmentally friendly charcoal production system using a low cost retort-kiln (Eco-charcoal). Renewable Energy, 2009, 34, 1923-1925

110. Klavina K, Klavins J, Veidenbergs I, Blumberga D: Charcoal production in a continuous operation retort. Experimental data processing. Energy Procedia, 2016, 95, 208-215

111. Szymkowski CJ, Bultitude-Paull JM: The Production of High quality Silicon Metal at Simcoa. INFACON 6, Proceedings of the $6^{\text {th }}$ International Ferroalloys Congress, Cape Town, Volume 1. Johannsburg, SAIMM, 1992, 185-191. 
112. Reumerman PJ, Frederiks B: Carbon Production with Reduced Emissions. $12^{\text {th }}$ Europen Confrence on Biomass for Energy, Industry and Climate Protection, Amsterdam, 2002, http://www.cleanfuels.nl/Sitepdfs/Charcoal\%20Production $\% 20$ with\%20Reduced\%20Emissi ons $\% 20$ (paper).pdf

113. Bates JS: Distillation of hardwoods in Canada. Forestry Branch-Bulletin \# 74, Department of the Interior, Canada. 1922.

114. FAO, Industrial Technologies for Charcoal Making, FAO Forestry paper 63, 1985. Available at: http://www.fao.org/docrep/x5555e/x5555e00.htm\#Contents

115. Siemons R. Industrial Charcoal production, 2008, FAO TCP/CRO/3101 (A) Development of a sustainable Charcoal industry.

116. Mura E, Debono O, Villot A, Paviet F: Pyrolysis of biomass in a semi-industrial scale reactor: Study of the fuel-nitrogen oxidation during combustion of volatiles. Biomass and Bioenergy, 2013, 59, 187-194

117. Pakdel H, Roy C: Chemical Characterization of Wood Pyrolysis oils obtained in a VacuumPyrolysis Multiple-Hearth Reactor. In: ACS Symposium Series, Vol. 376, Pyrolysis Oils from Biomass. Chapter 19, 1988, 203-219

118. Lemieux R, Roy C, de Caumia B, Blanchette D: Preliminary Engineering Data for Scale up of a Biomass vacuum pyrolysis reactor. ACS Division of Fuel Chemistry, Reprints, 1987, $32,2,12-20$.

119. Malkow, T., Novel and innovative pyrolysis and gasification technologies for energy efficient and environmentally sound MSW disposal, Waste Management, 2004, 24, 53-79

120. Fukushima, M., Wu, B., Ibe, H., Wakai, K., Sugiyama, E., Abe, H., Kitagawa, K., et al., Study on dechlorination technology for municipal waste plastics containing polyvinyl chloride and polyethylene terephthalate, J Mater Cycles Waste Manag, 2010, 12, 108-122.

121. Coates R.L., Eddings E.G., Coates B.R. Bio-oil yields from pyrolysis in a novel rotary reactor. Symposium on Thermal and Catalytic Sciences for Biofuels and Biobased Products. Iowa State University, September 21-23, 2010

122. Coates R, Gardner T, Eddings E: Mobile Pyrolysis Process for Conversion of Biomass Into Energy products. Presentation at the 2013 North American Biochar Symposium, October 13-16, 2013. file://C:/Users/mgarcia-perez/Downloads/F\&P\%20Amaron\%20Energy.pdf 
123. Sangines P, Dominguez MP, Sznchez F, San Miguel G. Slow pyrolysis of olive stones in a rotary kiln: Chemical and energy characterization of solid, gas, and condensable products. Journal of Renewable and Sustainable Energy, 2015;7,4, 043103.

124. Brown, J.N., Brown, R.C.. Process optimization of an auger pyrolyzer with heat carrier using response surface methodology. Bio resource Technology, 2012, 103, 405-414

125. Ingram L, Mohan D, Bricka M, Steele P, Strobel D, Crocker D, et al. Pyrolysis of wood and bark in an auger reactor: Physical properties and chemical analysis of the produced bio-oils. Energy\&Fuels, 2008;22, 1, 614-625.

126. Puy N, Murillo R, Navarro MV, López JM, Rieradevall J, Fowler G, et al. Valorisation of forestry waste by pyrolysis in an auger reactor. Waste Management 2011;31, 6, 1339.

127. Gajjela SK, Mitchell B, Li Q, Hassan EBM, Steele PH. Production of bio-fuels from giant miscanthus. 11AIChE - 2011 AIChE Spring Meeting and 7th Global Congress on Process Safety, Conference Proceedings; 2011

128. Wang H, Srinivasan R, Yu F, Steele P, Li Q, Mitchell B. Effect of acid, alkali, and steam explosion pretreatments on characteristics of bio-oil produced from pinewood. Energy\& Fuels, 2011, 25, 8, 3758.

129. Joubert JE, Carrier M, Dahmen N, Stahl R, Knoetze JH. Inherent process variations between fast pyrolysis technologies: A case study on Eucalyptus grandis. Fuel Processing Technology 2015, 131, 389.

130. Wang H, Srinivasan R, Yu F, Steele P, Li Q, Mitchell B, et al. Effect of Acid, Steam Explosion, and Size Reduction Pretreatments on Bio-oil Production from Sweetgum, Switchgrass, and Corn Stover. Applied Biochemistry and Biotechnology, 2012;167, 2, 285297.

131. Nam H, Capareda SC, Ashwath N, Kongkasawan J. Experimental investigation of pyrolysis of rice straw using bench-scale auger, batch and fluidized bed reactors. Energy 2015, 93, 2384-2394.

132.Pfitzer C, Dahmen N, Troger N, Weirich F, Sauer J, Gunther A, et al. Fast Pyrolysis of Wheat Straw in the Bioliq Pilot Plant. Energy \& Fuels, 2016;30, 10, 8047-8054. 
133. Henrich E, Dahmen N, Weirich F, Reimert R, Kornmayer C. Fast pyrolysis of lignocellulosics in a twin screw mixer reactor. Fuel Processing Technology, 2016;143, 151161.

134. Roy C., Blanchette D., korving L., Yang J., de Caumia B., Development of a Novel Vacuum Pyrolysis Reactor with improved heat transfer Potential. In: Developments in: Thermochemical Biomass Conversion. A.V. Bridgwater and D.G.B. Boocock, Eds., Blackie Academic and Professional, London, UK, 1997, 351-367.

135. Roy C., Lemieux S., de Caumia B., Pakdel H., Vacuum Pyrolysis of Biomass in a Multiple Heat Furnace. Biotechnology and Bioenegy, Sym. No 15, 1985, 107.

136. Venderbosch RH, Prins W., Fast Pyrolysis technology development. Biofuels, Bio-products and Biorefining, 2010, 4, 178-208

137. Tsai WT, Lee MK, Chang YM. Fast pyrolysis of rice husk: Product yields and compositions. Bioresource Technology, 2007;98, 1,:22.

138. Imam T, Capareda S. Characterization of bio-oil, syn-gas and char from switchgrass pyrolysis at various temperatures. J. Anal. Appl. Pyrolysis 2012;93, 170.

139. Fan Y, Cai Y, Li X, Yin H, Yu N, Zhang R, et al. Rape straw as a source of bio-oil via vacuum pyrolysis: Optimization of bio-oil yield using orthogonal design method and characterization of bio-oil. J. Anal. Appl. Pyrolysis, 2014;106, 63.

140. Dewayanto N, Isha R, Nordin MR. Use of palm oil decanter cake as a new substrate for the production of bio-oil by vacuum pyrolysis. Energy Conversion and Management 2014, 86, 226.

141. Fukuda S. Pyrolysis investigation for bio-oil production from various biomass feedstocks in Thailand. International Journal of Green Energy, 2015, 12, 3, 215.

142. Le Brech Y, Jia L, Cissé S, Mauviel G, Brosse N, Dufour A. Mechanisms of biomass pyrolysis studied by combining a fixed bed reactor with advanced gas analysis. J. Anal. Appl. Pyrolysis, 2016, 117, 334.

143. Xu Y, Wang T, Ma L, Zhang Q, Chen G. Technology of bio-oil preparation by vacuum pyrolysis of pine straw. Nongye Gongcheng Xuebao/Transactions of the Chinese Society of Agricultural Engineering, 2013, 29, 1, 196. 
144. Fan YS, Cai YX, Li XH, Yu N, Chen L. Comparison of the products in vacuum pyrolysis vapors derived from non-catalytic and catalytic upgrading of camphorwood sawdust. Chemistry and Industry of Forest Products, 2015, 35, 1, 70.

145. Li R., Deng X. S., Gou J. S., Lv Z. L.: Vacuum Paddle Fast Pyrolysis Reactor Design and Internal Heat Transfer Investigation, Materials Science Forum, 2012, Vols. 704-705, 468474

146. Rudloff M. Biomass to Liquid Fuels (BtL) Presentation made by Choren. Process, Environmental Impact and Latest Developments. Automobile \& Environment at Beograd Congress, May 2005.

147. Meier D, Faix O: State of the art of applied fast pyrolysis of lignicellulosic materials $-\mathrm{a}$ review. Bioresour Technol 1999, 68, 71-77.

148. Scott,D., Majerski, P., Piskorz, J., Radlein,D., A second look at fast pyrolysis of biomassthe RTI process, J. Anal. Appl. Pyrolysis, 1999, 51, 23-37

149. DynaMotive Energy _ Systems Corporation, BioTherm ${ }^{\mathrm{TM}}$, A System for Continuous Quality, Fast Pyrolysis BioOil, Fourth Biomass Conference of the Americas, Oakland, California, September 1, 1999

150. Lu Q, Yang X-1, Zhu X-f. Analysis on chemical and physical properties of bio-oil pyrolyzed from rice husk. J. Anal. Appl. Pyrolysis, 2008;82, 2, 191.

151. Heo HS, Park HJ, Dong J-I, Park SH, Kim S, Suh DJ, et al. Fast pyrolysis of rice husk under different reaction conditions. Journal of Industrial and Engineering Chemistry, $2010 ; 16,1,27$

152. Ji-lu Z. Bio-oil from fast pyrolysis of rice husk: Yields and related properties and improvement of the pyrolysis system. J. Anal. Appl. Pyrolysis, 2007;80, 1, 30.

153. Phan BMQ, Duong LT, Nguyen VD, Tran TB, Nguyen MHH, Nguyen LH, et al. Evaluation of the production potential of bio-oil from Vietnamese biomass resources by fast pyrolysis. Biomass and Bioenergy, 2014;62, 74.

154. Montoya JL, Valdes C, Chejne F, Gomez CA, Blanco A, Marrugo G, Osorio J, Castillo E, Aristobulo J, Acero J: Bio-oil production from Colombian bagasse by fast pyrolysis in a fluidized bed: An experimental study. J. Anal. Appl. Pyrolysis, 2015, 112, 379-387 
155. Oasmaa A, Solantausta Y, Arpiainen V, Kuoppala E, Sipilä K. Fast pyrolysis bio-oils from wood and agricultural residues. Energy \& Fuels, 2010; 24, 2, 1380.

156. Greenhalf CE, Nowakowski DJ, Harms AB, Titiloye JO, Bridgwater AV. A comparative study of straw, perennial grasses and hardwoods in terms of fast pyrolysis products. Fuel, 2013;108, 216.

157. Boateng, A.A., Daugaard, D.E., Goldberg, N.M., Hicks, K.B., Bench-Scale Fluidized-Bed Pyrolysis of Switchgrass for Bio-Oil Production. Ind. Eng. Chem. Res. 2007, 46, 1891-1897

158. Jendoubi N, Broust F, Commandre JM, Mauviel G, Sardin M, Lédé J. Inorganics distribution in bio oils and char produced by biomass fast pyrolysis: The key role of aerosols. J. Anal. Appl. Pyrolysis, 2011;92, 1, 59.

159. Westerhof RJM, Brilman DWF, van Swaaij WPM, Kersten SRA: Effect of temperature in fluidized bed fast pyrolysis of biomass: oil quality assessment in tests units. Ind. Eng. Chem Res, 2010, 49, 1160-1168

160. Kim KH, Kim T-S, Lee S-M, Choi D, Yeo H, Choi I-G, et al. Comparison of physicochemical features of biooils and biochars produced from various woody biomasses by fast pyrolysis. Renewable Energy 2013;50, 188.

161. Soysa R, Choi SK, Jeong YW, Kim SJ, Choi YS. Pyrolysis of Douglas fir and coffee ground and product biocrude-oil characteristics. J. Anal. Appl. Pyrolysis, 2015;115, 51.

162. Wu S-R, Chang C-C, Chang Y-H, Wan H-P. Comparison of oil-tea shell and Douglas-fir sawdust for the production of bio-oils and chars in a fluidized-bed fast pyrolysis system. Fuel, 2016;175, 57.

163. Azeez AM, Meier D, Odermatt J, Willner T. Fast pyrolysis of African and European lignocellulosic biomasses using Py-GC/MS and fluidized bed reactor. Energy\&Fuels 2010;24, 3, 2078.

164. Rover MR, Johnston PA, Whitmer LE, Smith RG, Brown RC. The effect of pyrolysis temperature on recovery of bio-oil as distinctive stage fractions. J. Anal. Appl. Pyrolysis 2014;105, 262.

165. Mullen CA, Boateng AA, Goldberg NM. Production of deoxygenated biomass fast pyrolysis oils via product gas recycling. Energy\&Fuels, 2013;27, 7, 3867. 
166. Torri IDV, Paasikallio V, Faccini CS, Huff R, Caramão EB, Sacon V, et al. Bio-oil production of softwood and hardwood forest industry residues through fast and intermediate pyrolysis and its chromatographic characterization. Bioresource Technology, 2016;200, 680.

167. Carrier M, Joubert JE, Danje S, Hugo T, Görgens J, Knoetze JH. Impact of the lignocellulosic material on fast pyrolysis yields and product quality. Bioresource Technology, 2013;150, 129.

168. He M, Mourant D, Gunawan R, Lievens C, Wang XS, Ling K, et al. Yield and properties of bio-oil from the pyrolysis of mallee leaves in a fluidised-bed reactor. Fuel, 2012;102, 506.

169. Chang S, Zhao Z, Zheng A, Li X, Wang X, Huang Z, et al. Effect of hydrothermal pretreatment on properties of bio-oil produced from fast pyrolysis of eucalyptus wood in a fluidized bed reactor. Bioresource Technology, 2013;138, 321.

170. Heidari A, Stahl R, Younesi H, Rashidi A, Troeger N, Ghoreyshi AA. Effect of process conditions on product yield and composition of fast pyrolysis of Eucalyptus grandis in fluidized bed reactor. Journal of Industrial and Engineering Chemistry, 2014;20, 4,2594.

171. Atsonios K, Panopoulos KD, Bridgwater AV, Kakaras E. Biomass fast pyrolysis energy balance of a 1kg/h test rig. International Journal of Thermodynamics, 2015;18, 4, 267.

172. Mesa-Pérez JM, Cortez LAB, Marín-Mesa HR, Rocha JD, Pelaez-Samaniego MR, Cascarosa E. A statistical analysis of the auto thermal fast pyrolysis of elephant grass in fluidized bed reactor based on produced charcoal. Applied Thermal Engineering, 2014, 65, $1-2,322-329$.

173. Faix, A., Schweinle, J., Schöll, S., Becker, G., Meier, D., (GTI-tcbiomass) Life-Cycle Assessment of the BTO_-Process (Biomass-to-Oil) with Combined Heat and Power Generation, Environmental Progress \& Sustainable Energy, 29, 2, 2010.

174. Meier, D., Schöll, S., Klaubert, H., Markgraf, J., (n.d.), Practical results from Pytec's biomass to-oil (BTO) process with ablative pyrolyser and diesel CHP plant, Success \& Visions for Bioenergy, http://www.pytecsite.de/pytec_eng/publikationen.htm

175. Bridgwater AV, Meier D, Radlein D: An overview of fast pyrolysis of biomass. Organic Geochemistry, 30, 1999, 1479-1493.

176. Schulzke T, Conrad S, Westermeyer J. Fractionation of flash pyrolysis condensates by staged condensation. Biomass and Bioenergy, 2016, 95, 287-295 
177. Bech N, Larsen MB, Jensen PA, Dam-Johansen K. Modelling solid-convective flash pyrolysis of straw and wood in the Pyrolysis Centrifuge Reactor. Biomass and Bioenergy, 2009; 33, 6-7, 999.

178. Makibar J, Fernandez-Akarregi AR, Amutio M, Lopez G, Olazar M. Performance of a conical spouted bed pilot plant for bio-oil production by poplar flash pyrolysis. Fuel Processing Technology, 2015;137, 283.

179. Alvarez J, Lopez G, Amutio M, Bilbao J, Olazar M. Bio-oil production from rice husk fast pyrolysis in a conical spouted bed reactor. Fuel, 2014;128, 162.

180. Amutio M, Lopez G, Alvarez J, Moreira R, Duarte G, Nunes J, et al. Flash pyrolysis of forestry residues from the Portuguese Central Inland Region within the framework of the BioREFINA-Ter project. Bioresource Technology, 2013;129, 512.

181. Du S, Sun Y, Gamliel DP, Valla JA, Bollas GM. Catalytic pyrolysis of miscanthus $\times$ giganteus in a spouted bed reactor. Bioresource Technology, 2014;169, 188.

182. Amutio M, Lopez G, Artetxe M, Elordi G, Olazar M, Bilbao J. Influence of temperature on biomass pyrolysis in a conical spouted bed reactor. Resources, Conservation and Recycling 2012;59, 23.

183. Chen M, Yao Y, Ren Z, Li T, Guo X, Yan Y. Preparation of liquid fuel through pyrolysis of biomass in a conduit-spouting fluidized reactor. Proceedings of the 2003 5th International Symposium on Coal Combustion; 2003, 272.

184. Amutio M, Lopez G, Alvarez J, Olazar M, Bilbao J. Fast pyrolysis of eucalyptus waste in a conical spouted bed reactor. Bioresource Technology, 2015; 194, 225.

185. Lam SS, Chase HA: A review on Waste to Energy Processes using Microwave Pyrolysis. Energies, 2012, 5, 4209-4232

186. Li J, Dai J, Liu G, Zhang H, Gao Z, Fu J, He Y, Huang Y: Biochar from microwave pyrolysis of biomass: A review. Biomass and Bioenergy, 94 (2016), 228-244

187. Holland KM, Apparatus for Waste Pyrolysis, US Patent 5,387,321, 7 February 1995

188. Holland KM, Process for Destructive Distillation of Organic Materials. U.S. Patent 5,330,623, May 1994

189. Zhao X, Wang M, Liu H, Li L, Ma C, Song Z: A microwave reactor for characterization of pyrolyzed biomass. Bioresource Technology, 2012, 104, 673-678

64 
190. Miura M, Kaga H, Sakurai A, Kakuchi T, Rapid pyrolysis of woof block by microwave heating. J. Analytical and applied Pyrolysis. 71, 2004, 187-199

191. Hu Z, Ma X, Chen C. A study on experimental characteristic of microwave assisted pyrolysis of microalgae. Bioresource Technology, 2012, 107, 487-493

192.Ren S, Lei H, Wang L, Bu Q, Chen S, Wu J, et al. Biofuel production and kinetics analysis for microwave pyrolysis of Douglas fir sawdust pellet. Journal of Analytical and Applied Pyrolysis 2012; 94: 163-169

193. Tian Y, Zuo W, Ren Z, Chen D. Estimation of a novel method to produce biooil from sewage sludge by microwave pyrolysis with the consideration of efficiency and safety. Bioresource Technology 2011;102:2053-61

194. Huang YF, Kuan WH, Lo SL, Lin CF. Hydrogen-rich fuel gas from rice straw via microwave-induced pyrolysis. Bioresource Technology 2010;101: 1968-73

195. Salema AA, Ani FN. Microwave induced pyrolysis of oil palm biomass. Bioresource Technology 2011;102: 3388-3395.

196. Du Z, Li Y, Wang X, Wan Y, Chen Q, Wang C, et al. Microwave-assisted pyrolysis of microalgae for biofuel production. Bioresource Technology 2011;102: 4890-4896

197. Lin Q, Chen G, Liu Y. Scale-up of microwave heating process for the production of bio-oil from sewage sludge. Journal of Analytical and Applied Pyrolysis 2012;94: 114-119.

198. Huang YF, Kuan WH, Lo SL, Lin CF. Total recovery of resources and energy from rice straw using microwave-induced pyrolysis. Bioresource Technology 2008; 99: 8252-8258

199. Salema AA, Ani FN. Microwave-assisted pyrolysis of oil palm shell biomass using an overhead stirrer. Journal of Analytical and Applied Pyrolysis 2012; 96: 162-72

200. Yu F, Ruan R, Steele P. Microwave pyrolysis of corn stover. Transactions of the American Society of Agricultural and Biological Engineers 2009; 52: 1595-601

201. Wang MJ, Huang YF, Chiueh PT, Kuan WH, Lo SL. Microwave-induced torrefaction of rice husk and sugarcane residues. Energy 2012; 37: 177-84

202.Mesa-Perez JM, Fonseca-Felfli: Chapter 9: Technical and Marketing Criteria for the Development of Fast Pyrolysis technologies. In: Innovative Solutions and Fluid-Particle Systems and Renewable energy Management. Editor: Katia Tannous (Unicamp Brazil), 2015 
203. Garcia-Perez M, Garcia-Nunez JA, Pelaez-Samaniego MR, Kruger C, Fuchs MR, Flora G: Sustainability, Chapter 10. Business Models and Techno-economic Analysis of Biomass Pyrolysis Technologies. In: Innovative Solutions and Fluid-Particle Systems and Renewable energy Management. Editor: Katia Tannous (Unicamp Brazil), 2015

204.Jones SB, Valkenburg C, Walton C, Elliott DC, Holladay JE, Stevens DJ, Kinchin C, Czernik S: Production of gasoline and Diesel from biomass via fast pyrolysis, hydrotreating and hydrocracking: A dessign case. Prepared for the U.S. Department of Energy under Contract DE-AC05-76RL01830. PNNL-18284 Rev. 1, June 2009

205. Daugaard DE, Brown RC: Enthalpy of pyrolysis for several types of biomass. Energy \& Fuels, 2003, 17, 934-939

206. Catoire L, Yahyaouo M, Osmont A, Gokalp I: Thermochemistry of Compounds Formed during Fast Pyrolysis of Lignocellulosic Biomass. Energy \& Fuels 2008, 22, 4265-4273

207. Auber M: Effect catalytique de certains inorganiques sur la selectivite des reactions de pyrolyse rapide de biomasses et de leurs constituants. PhD thesis. Institut National Polytechnique de Lorraine. 2009

208. Yang H, Kudo S, Huo H-P, Norinaga K, Mori A, Masek O, Hayashi J-I: Estimation of Enthalpy of Bio-oil Vapor and Heat Required for Pyrolysis of Biomass. Energy \& Fuels $2013,27,2675-2686$

209. Janse AMC, Westerhout RWJ, Prins W: Modelling of flas pyrolysis of a single wood particle. Chemical Engineering and Processing 39 (2000), 239-252

210. Wang X, Kersten S.R.A., Prins W, van Swaaij W.P.M: Biomass Pyrolysis in a Fluidized Bed Reactor. Part 2: Experimental Validation of Model Results. Ind. Eng. Chem. Res. 2005, $44,8786-8795$

211.Thunman H, Lecker B: Thermal conductivity of wood-models for different stages of combustion. Biomass and Bioenergy 23 (2002) 47-54

212. Boateng AA: Rotary Kilns. Transport Phenomena and Transport Processes. ButterworthHeinemann, 2008

213.Basu P: Combustion and Gasification in Fluidized beds. Taylor \& Francis. 2006.

214.Zhong W, Jin B, Wang X, Xiao R: Fluidization of Biomass Particles in a Gas-Solid Fluid Bed. Energy \& Fuel 2008, 22 (6), 4170-4176 
215. Bruni G, Solimene R, Marzocchella A, Salatino P, Yates JG, Lettieri P, Fiorentino M: Selfsegregation of high-volatile fuel particle devolatilization in a fluidized bed reactor. Powder Technology 128 (2002) 11-21

216. Yoder J, Galinato S, Granatstein D, Garcia-Perez M: Economic treadoff between biochar and bio-oil production via pyrolysis. Biomass and Bioenergy, 2011, 35, 5, 1851-1862

217. Bailis R: Modeling climate change mitigation from alternative methods of charcoal production in Kenya. Biomass and Bioenergy, 2009, 33, 11, 1491-1502

218. Ronsse F, Nachenius R, Prins W: Carbonization of Biomass. In: Recent advances in thermochemical conversion of biomass. Edited by: Pandey A, Bashkar T, Stocker M, Sukumaran R, 2015, 293-324

219. Siemons, R., Baaijens, L. An Innovative Carbonisation Retort: Technology and Environmental Impact. Termotehnika, 2012, 38, 2, 131-138.

220. Jahanshaki S, Mathieson JG, Somerville MA, Haque N, Norgate TE, Deev A, Pan Y, Xie D, Ridgeway P, Zulli P: Development of low-emission Integrated Steelmaking Process. Journal of Sustainable Metallurgy, 2015, 1, 1, 94-114

221. N. Dahmen, E. Dinjus, E. Heinrich, The Karlsruhe Process bioliq ${ }^{\circledR}:$ Synthetic Fuels from the Biomass. In: Renewable Energy: Sustainable Energy Concepts for the Future, R. Wengenmayr (Editor), T. Buhrke (Editor). Wiley, 2008. ISBN: 978-3-527-40804-7

222. Jager N, Conti R, Neumann J, Apfelbacher A, Daschner R, Binder S, Hornung A: ThermoCatalytic Reforming of Wood Biomass. Energy\&Fuels, 2016, 30, 10, 7923-7929

223. Moriconi N, Laranci P, D’Amico M, Bartocci P, D’Alessandro B, Cinto G, Baldinelli A, Discepoli G, Bidini G, Desideri U, Cotana F, Fantozzi F: Design and preliminary operation of a Gasification Plant for Micro-CHP with Internal Combustion engine and SOFC. Energy Procedia, Vol. 81, 2015, 298-308, $69^{\text {th }}$ Conference of the Italian Thermal Engineering Association, ATI 2014. 


\section{Graphical abstract}

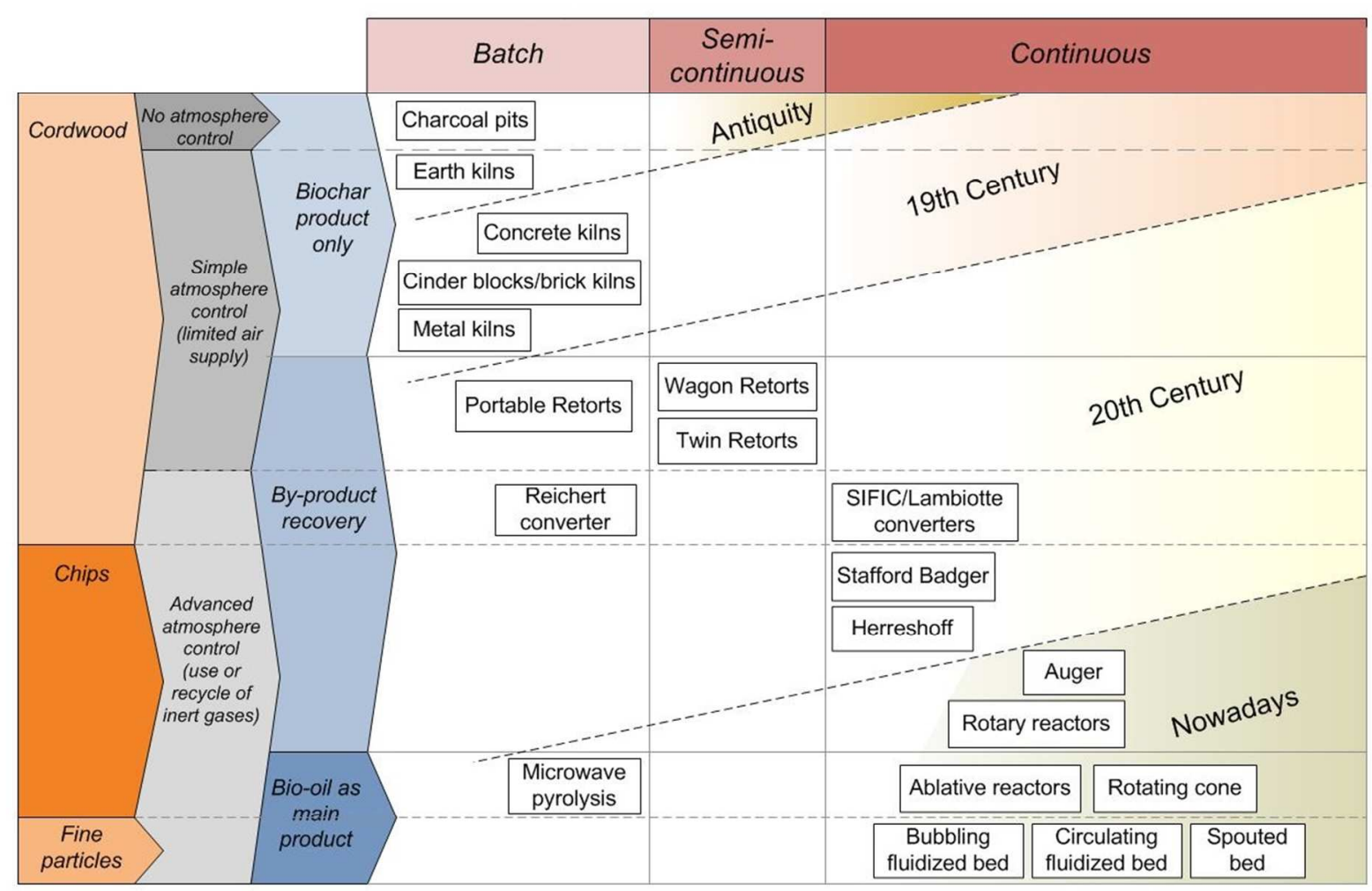

